Pontifícia Universidade Católica $_{\text {a }}$

DO RIO DE JANEIRO

Célia Câmara de Araújo

Linguagem, Infância e Perspectivismo nos Escritos Maduros de Wittgenstein

\title{
Tese de Doutorado
}

Tese apresentada ao Programa de Pós-graduação em Estudos da Linguagem da PUC-Rio como requisito parcial para obtenção do título de Doutor em Letras/Estudos da Linguagem.

Orientadora: Prof ${ }^{a}$ Helena Franco Martins

Rio de Janeiro

Fevereiro de 2016 
Pontifícia Universidade Católica $_{\text {a }}$

DO RIO DE JANEIRO

Célia Câmara de Araújo

\title{
Linguagem, infância e perspectivismo nos escritos Maduros de Wittgenstein
}

Tese apresentada como requisito parcial para obtenção do grau de Doutor pelo Programa de Pós-Graduação em Estudos da Linguagem da PUC-Rio. Aprovada pela Comissão Examinadora abaixo assinada.

\author{
Profa. Helena Franco Martins \\ Orientadora \\ Departamento de Letras - PUC-Rio \\ Profa. Maria Paula Frota \\ Departamento de Letras - PUC-Rio \\ Prof. Paulo Fernando Henriques Britto \\ Departamento de Letras - PUC-Rio
}

Profa. Maria Claudia Gonçalves Maia Americano do Brasil

IUPERJ-Tec

Profa. Ana Paula Grillo El-Jaick

UFJF

Profa. Denise Berruezo Portinari Coordenadora Setorial do Centro de Teologia

e Ciências Humanas - PUC-Rio

Rio de Janeiro, 29 de fevereiro de 2016. 
Todos os direitos reservados. É proibida a reprodução total ou parcial do trabalho sem autorização da universidade, da autora e da orientadora.

\section{Célia Câmara de Araújo}

Possui bacharelado e licenciatura em Letras (1989) pela Faculdade de Letras da UFRJ (Universidade Federal do Rio de Janeiro) onde foi bolsista de Iniciação Científica pelo $\mathrm{CNPq}$ sob orientação do Prof. Celso Cunha. É Mestre em Letras, Linguística (2005) pela PUCRS (Pontifícia Universidade Católica do Rio Grande do Sul, bolsista CAPES). Possui também os diplomas da Université de Nancy I, II e III (1992-4) pela Universidade de Nancy, França. Possui experiência de ensino da língua materna (português) para Ensino Fundamental e Médio e ensino de língua estrangeira (francês) em cursos da Aliança Francesa. Atualmente leciona as disciplinas Ética e Epistemologia no Curso Básico em Engenharia do Instituto Militar de Engenharia (IME) e Iniciação à Escrita Acadêmica nos cursos de Pós-Graduação do IME.

Ficha Catalográfica

Araújo, Célia Câmara de
Linguagem, infância e perspectivismo nos escritos
maduros de Wittgenstein / Célia Câmara de Araújo; orientadora:
Helena Franco Martins. - 2016.
146 f. ; $30 \mathrm{~cm}$
Tese (doutorado) - Pontifícia Universidade Católica do
Rio de Janeiro, Departamento de Letras, 2016.
Inclui bibliografia
1. Letras - Teses. 2. Wittgenstein. 3. Perspectivismo.
4. Perspectivismo ameríndio. 5. Alteridade. 6. Linguagem. I.
Martins, Helena Franco. II. Pontifícia Universidade Católica do
Rio de Janeiro. Departamento de Letras. Ill. Título.

CDD: 400 


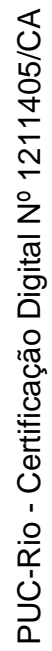

Para Selene, Larissa, Katharina e Helena. 


\section{Agradecimentos}

À PUC-Rio e à CAPES pelos auxílios concedidos sem os quais este trabalho não teria sido concretizado.

À Prof ${ }^{\mathrm{a}}$ Dr $^{\mathrm{a}}$ Helena Franco Martins por ter me dado a mão com firmeza ao longo dessa caminhada.

Aos alunos e colegas do Instituto Militar de Engenharia pelas interlocuções preciosas quando discutimos os textos sobre ética e epistemologia que me levaram ao desafio que se constituiu esse percurso em que pude aprofundar o diálogo entre linguagem e filosofia.

À secretária da Pós-Graduação em Letras, Chiquinha, por seu trabalho diligente e silencioso, e por sua doçura e amabilidade constantes.

Às minhas filhas e genros, por estarem pacientemente ao meu lado, apesar do mesmo assunto, sempre. À menina Helena, especialmente, pela "fita verde".

À minha família, meus pais e meus irmãos, agradeço pelo desafio da convivência. Agradeço reverentemente ao "Cacique Chuva-na-Cara" por ter me abençoado com a possibilidade de espanto e de admiração pela Vida, concomitantes ao reconhecimento da ignorância e da pequenez face ao sagrado. Agradeço, por fim, a Tuwi 'xawa, a onça do morro, por continuar entre nós com alegria e fé. 


\section{Resumo}

Araújo, Célia Câmara de; Martins, Helena Franco (Orientadora). Linguagem, infância e perspectivismo nos escritos maduros de Wittgenstein. Rio de Janeiro, 2016. 146p. Tese de Doutorado - Departamento de Letras, Pontifícia Universidade Católica do Rio de Janeiro.

Esta pesquisa examina cenas de alteridade radical entre crianças e adultos nos escritos maduros de Wittgenstein. Demonstra-se como tais cenas ajudam a construir uma visão da linguagem como forma de vida, capaz de recusar tanto o universalismo como o relativismo, em benefício de uma compreensão perspectivista. Os escritos de Ludwig Wittgenstein posteriores ao Tractatus Logico-Philosophicus, obra escrita ainda nos seus anos de juventude, são mais frequentemente compreendidos como um pensamento que tende ao relativismo, opondo-se, portanto, frontalmente ao trabalho inicial do filósofo. Esta pesquisa aponta para uma filosofia única, nos termos da interpretação que lhe dá o filósofo e pesquisador brasileiro Bento Prado Jr., para quem o télos da filosofia wittgensteiniana jamais se modificou. Assim, nem universalismo, nem relativismo seriam contemplados pelo pensamento de Wittgenstein, havendo, isto sim, uma filosofia perspectiva, aproximável, sob certos aspectos, daquelas que encontramos, por exemplo, em Nietzsche e Deleuze. Para melhor entendimento do perspectivismo na filosofia de Wittgenstein, e, em consonância com o projeto de pesquisa a que nos vinculamos, procedeu-se à análise do que se pode chamar de cenas de alteridade radical nos escritos wittgensteinianos - experimentos de pensamento que comparecem com muita frequência nos últimos escritos do filósofo. Trata-se de cenas imaginárias que figuram encontros, perplexidades e incompreensões entre selvagens e civilizados, loucos e sãos, orientais e ocidentais, crianças e adultos, e assim por diante. Nesses experimentos, manifesta-se o rigor do trabalho crítico de Wittgenstein sobre a linguagem e o significado, sempre concomitante à sua crítica da metafísica. Este trabalho se concentrou na identificação e análise de cenas relacionadas à alteridade adulto vs. criança, assumindo que o conceito de infância pode ser alargado em relação ao período cronológico a que frequentemente está vinculado, como propõe o filósofo italiano Giorgio Agamben. Averiguou-se, a partir do exame dessas cenas, em que medida essa alteridade funciona como índice de perspectivismo nos escritos da fase mais madura de Wittgenstein e em que medida as cenas de alteridade deixam entrever a ideia wittgensteiniana de forma de vida. Para compreender a elusiva noção de forma de vida em Wittgenstein, não nos esquivamos também de um encontro com a antropologia - área cujas preocupações centrais estão reconhecidamente presentes nos escritos do filósofo vienense. Privilegiamos, nesse encontro, o trabalho etnofilosófico do antropólogo Eduardo Viveiros de Castro. A análise do Corpus wittgensteiniano em contágio com a etnofilosofia de Viveiros de Castro indica pontos de convergência entre o pensamento de Wittgenstein - e o das filosofias perspectivistas em geral - e a cosmologia ameríndia tal como apresentada por Viveiros de Castro. A pesquisa empreendida dá a ver uma modalidade wittgensteiniana de perspectivismo, as formas singulares com que o filósofo permite acolher uma multiplicidade de mundos na recusa básica da ideia de visão do mundo, na implosão da partição sujeito/objeto, no laço entre filosofia e poesia.

\section{Palavras-chave}

Wittgenstein; perspectivismo; perspectivismo ameríndio; alteridade; linguagem; infância. 


\section{Abstract}

Araújo, Célia Câmara de; Martins, Helena Franco (Advisor). Language, childhood and perspectivism in Wittgenstein's late writings. Rio de Janeiro, 2016. 146p. Doctoral Thesis - Departamento de Letras, Pontifícia Universidade Católica do Rio de Janeiro.

This research focuses specifically on the examination of scenes of extreme alterity between children and adults, with the aim of demonstrating the way in which these scenes help to construct a vision of language as a form of life, managing to reject universalism as well as relativism, favouring instead a perspectivist understanding. Ludwig Wittgenstein's writings post-Tractatus Logico-Philosophicus, a work he completed in his younger years, are more often than not interpreted with a way of thinking which tends towards relativism and which directly contradicts the first work of the philosopher, most commonly interpreted as a work that tends towards universalism. This research points towards a singular philosophy, in terms of the interpretation put forward by Brazilian researcher and philosopher Bento Prado Jr., according to whom the telos of Wittgensteinian philosophy has never wavered. Thereby, neither universalism nor relativism are contemplated in the Wittgensteinian thinking, rather a perspective philosophy, comparable in certain aspects to the philosophy of, for example, Nietzsche and Deleuze. For a better understanding of perspectivism in Wittgenstein's philosophy, in harmony with the research project that we have adhered to, an analysis of what can be called scenes of radical alterity in Wittgenstinian writing has been undertaken - a type of thought experiment that occurs with great frequency in the late work of the philosopher. This appears in the form of imaginary scenes which depict encounters, perplexities and misunderstandings between savage and civilised individuals, crazy and sane individuals, easterners and westerners, children and adults, and so on. In these experiments, the rigour of Wittgenstein's critical work on language and meaning manifests itself, ever concomitant to his criticism of metaphysics. This work has been centered on the identification and analysis of scenes relating to adult versus child alterity, by assuming that the concept of childhood may be extended in relation to the chronological period with which it is frequently associated, as Italian philospher Giorgio Agamben proposes. The examination of such scenes has allowed the investigation into the extent to which this alterity works as an indication of perspectivism in the late writings of Wittgenstein and the extent to which the scenes of alterity illustrate the Wittgensteinian idea of the form of life. In order to understand the elusive notion of form of life according to Wittgenstein, we also must not avoid the ties to anthropology - the central questions of which are demonstrably present in the writings of the Viennese philosopher. In doing this, we give privilege to the ethnophilosophical work of anthropologist Eduardo Viveiros de Castro. The analysis of the Wittgensteinian corpus, coupled with the ethnophilosophy of Viveiros de Castro, indicates points of convergence between Wittgensteinian thought - and that of perspectivist philosophers in general - and Amerindian cosmology such as that presented by Viveiros de Castro. The research carried out sheds light on a Wittgensteinian form of perspectivism, the singular forms with which the philosopher allows the existance multiple worlds in the basic rejection of the idea of a world vision, in the implosion of the subject/object partition, in the ties between philosophy and poetry.

\section{Keywords}

Wittgenstein; perspectivism; Amerindian perspectivism; alterity; language; childhood. 


\section{Sumário}

1 Introdução 12

1.1. Objetivo 21

1.2. Metodologia 22

1.3. Justificativa 22

2 Wittgenstein: algumas noções relevantes 24

2.1. Os jogos de linguagem 25

2.1.1. Os jogos de linguagem e o ensino ostensivo $\quad 40$

2.2. A linguagem como forma de vida 48

2.2.1. Sobre crenças e certezas $\quad 51$

\begin{tabular}{ll} 
2.2.2. & Sobre ensino e certezas \\
\hline
\end{tabular}

3 Perspectivismos $\quad 62$

3.1. O perspectivismo na filosofia: Nietzsche e Wittgenstein 71

3.2. O perspectivismo ameríndio segundo Eduardo Viveiros de Castro 81

3.3 Um perspectivismo wittgensteiniano? Uma aproximação entre
Deleuze e Wittgenstein: a leitura de Prado Jr.

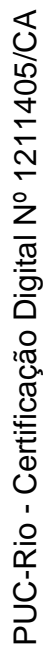

4 Infância, alteridade, ensino e perspectiva em Wittgenstein 105

4.1. Jogos de linguagem e forma de vida 114

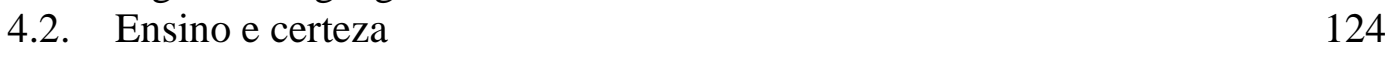

4.3. Alteridade e perspectivismo 129

5 Conclusões 135

6 Mapeamento do Corpus 140

7 Referências 142 
[NB] Notebooks 1914-16. H. von Wright e G. E. M. Anscombe (eds), trad. G. E. M. Anscombe, Oxford: Blackwell, 1998.

[TLP] Tractatus Logico-Philosophicus. Tradução, apresentação e estudo introdutório de Luiz Henrique Lopes dos Santos; [Introdução de Bertrand Russell]. - São Paulo: Editora Universidade de São Paulo, 2010.

[VB] Vermischte Bemerkungen / Culture and Value. Ed. G. H. von Wright, em colaboração com Heikki Nyman. Trad. Peter Winch. Oxford: Basil Blackwell, 1975. [Em português: Cultura e valor. Trad. Jorge Mendes. Lisboa: Edições 70, 1980.]

[PG] Philosophical Grammar. R. Rhees (ed.), trad. Anthony Kenny, Oxford: Blackwell, 1974. [Em português: Gramática Filosófica. Trad. Do inglês Luís Carlos Borges. São Paulo: Edições Loyola, 2003.]

[GB] Bemerkungen über Frazers Golden Bough /Remarks on Frazer's Golden Bough In [PO], pp.115-155. [Em português: Observações sobre o ramo de ouro de Frazer. Trad. E notas João José R. L. Almeida. Adverbum, vol. 2/2, 2007, pp. 186-231. Disponível em http://www.psicanaliseefilosofia.com.br/adverbum/vol22/observacoes_ramo_de_ouro.pdf. Acesso em 24/08/2014]

[BB] The Blue and Brown Books: Preliminary Studies for the "Philosophical Investigations". New York: Harper \& Row, 1965. [Em português: O livro azul. Trad. Jorge Mendes, Lisboa: Edições 70, 1992. I O livro castanho. Trad. Jorge Marques. Lisboa: Edições 70, 1992.]

[BF] Bemerkungen über die Farben / Remarks on Colour. G. E. M. Anscombe (ed.), Trad. Linda L. McAlister, Margarete Schättle, Oxford: Blackwell, 1980. [Em Português: Anotações sobre as cores. Apresentação, estabelecimento do texto, tradução e notas: João Carlos Salles Pires da Silva. Campinas: Editora da UNICAMP, 2009.]

[PU] Philophische Untersuchungen / Philosophical Investigations. Trad. G. E. M. Anscombe. Oxford: Blackwell, 1998. [Em português: Investigações Filosóficas. Trad. José Carlos Bruni, São Paulo: Editora Nova Cultural, 1999.]

[UG] Über Gewissheit/On certainty. [1951, H. von Wright e G. E. M. Anscombe (eds). Trad Denis Paul e G. E. M. Anscombe. Oxford: Blackwell, 1969. [Em português: Da certeza. Trad. Maria Elisa Costa, Lisboa: Edições 70, 1990.]

[Z] Zettel. G. H. von Wright, G. E. M. Anscombe (ed.), trad. G. E. M. Anscombe. Oxford: Blackwell, 1981. [Em português: Fichas/Zettel. Trad. Ana Berhan da Costa, Lisboa: Edições 70, 1989.] 
[LE] A Lecture on Ethics [1929]. [Em português: Conferência sobre ética.

Trad. Darley Dall'Agnol. Disponível em: https://ateus.net/artigos/filosofia/conferencia-sobre-etica/pdf/ Acesso em15/08/2012]

[GB] Bemerkungen überFrazers Golden Bough / Remarks on Frazer's Golden Bough. Em português: Observações sobre o Ramo de Ouro de Frazer. Trad. e notas de João José R. L. Almeida. Disponível em http://www.unicamp.br/ joaojose/observacoes_ramo_de_ouro.pdf. Acesso em $\underline{05 / 10 / 2014}$.

[RFM] Remarks on the Foundations of Mathematics [1937-44]. H. von Wright, G. E. M. Anscombe (eds.), trad. G. E. M. Anscombe, Oxford: Blackwell, 1978. 
Nada em rigor tem começo e coisa alguma tem fim, já que tudo se passa em ponto numa bola; e o espaço é o avesso de um silêncio onde o mundo dá suas voltas. Esferas com mares, em azul, que confecham terras de outras cores. Montanhas se figuram por fieirinhas de riscos. Os rios representam-se a traços, sinuosos mais ou menos. Aí e cada cidade é um centro, pingo ou não em pequeno círculo. Mas, o povoado...

Guimarães Rosa, A estória do Homem do Pinguelo 


\section{Introdução}

No prefácio das Investigações Filosóficas, obra mais difundida do chamado segundo Wittgenstein, o filósofo afirma que as observações de seu amigo Piero Sraffa, na época conferencista da área de Ciências Econômicas na Universidade de Cambridge, exerceram forte influência sobre seus pensamentos. Percebe-se, a partir desse encontro, a preocupação do filósofo em trazer a linguagem ordinária para o centro das discussões e observá-la em toda sua complexidade, tal como ela se apresenta em nosso cotidiano. O filósofo passa a valorizar não apenas as palavras isoladas das ações cotidianas, mas também o contexto, os gestos, o modo como somos, desde pequenos, introduzidos nas diversas situações de linguagem. Como nos explica Perloff:

É a formação desse uso "instintivo" da língua, uma série de hábitos que podem ser estudados antropologicamente - como argumentava seu amigo de Cambridge, o economista marxista italiano Piero Sraffa - que se tornou o novo foco de Wittgenstein (PERLOFF, 2008: 85).

Sua filosofia revela, a partir de então, relações entre linguagem e antropologia, aparecendo em seus escritos cenas de alteridade que se desenvolvem na atividade coletiva. Os escritos de Wittgenstein serão vistos, daí em diante, como antagônicos em relação à tese central do Tractatus, sua única obra publicada em vida, por passarem a conceber que os significados ocorrem como lances de um jogo, o que por sua vez significa dizer que são instáveis e, na filosofia madura de Wittgenstein, construídos no acordo de uma forma de vida. Dessa nova abordagem do significado surge uma exegese que vê o filósofo como um relativista, em franca oposição à sua primeira obra, percebida, não raras vezes, como uma obra de cunho universalista. Sobre tais interpretações, Prado Jr. (2004: 43) comenta que "aparentemente advogados e adversários do relativismo, acabam desencavando, dos textos de Wittgenstein, algumas teses, uma filosofia no sentido de uma doutrina ou de uma visão do mundo".

Observamos que a questão do significado se, por um lado, tem lugar privilegiado na filosofia wittgensteiniana - este lugar existe por conta da crítica à metafísica que está presente desde o Tractatus e não porque o filósofo tenha por 
meta fazer filosofia da linguagem. Por isso está claro no Tractatus, algo que não podemos desconsiderar: a tentativa de solucionar questões de ordem metafísica é um gesto de pura soberba filosófica.

Amparada pelo viés antropológico e baseada na leitura tanto do Tractatus como de obras da fase madura de Wittgenstein, esta pesquisa aponta para uma filosofia única em Wittgenstein, nos termos da interpretação que lhe dá o filósofo e pesquisador brasileiro Prado Jr. nos ensaios que compõem a publicação intitulada Erro, ilusão, loucura, lançados num único volume no ano de 2004. Para o pensador brasileiro, o télos dessa filosofia jamais se modificou, assim como tampouco abrigou universalismo ou relativismo, havendo, isso sim, uma filosofia perspectiva, aproximável, sob certos aspectos, daquelas que encontramos, por exemplo, em Nietzsche e Deleuze. Alinhando-se ao projeto da pesquisadora Helena Martins, o qual investiga a noção wittgensteiniana de "forma de vida" (lebensform), reconhecendo nessa noção "um índice possível de uma manifestação singular de perspectivismo no pensamento do filósofo" (MARTINS, 2013), este trabalho busca contribuir com as discussões que ampliam as já férteis possibilidades do pensamento wittgensteiniano ao sair da polarização universalismo-relativismo.

Como lembra Günter Gebauer, pesquisador da filosofia wittgensteiniana em suas relações com a antropologia, "as Investigações Filosóficas, sua obra principal retrabalhada durante anos, não têm uma estrutura explícita, mas sim oferecem ao leitor uma sequência de mudanças de perspectiva” (GEBAUER: 2013: 39). Não é possível, a partir desses escritos que compõem uma espécie de "álbum" - de acordo com as palavras do próprio filósofo - mostrando a mesma paisagem a partir de variados ângulos, conceber um filosofar dogmático. Da mesma forma, não é recomendável, se se quer seguir o movimento do próprio filósofo, estabelecer uma exegese homogênea, como mostrou a tendência de seus primeiros intérpretes (GEBAUER, 2013: 12; MARTINS, 2009: 20; PRADO Jr.,2004: 80).

Para melhor entendimento do perspectivismo na filosofia de Wittgenstein, percebemos ser de fundamental importância proceder à análise do que poderíamos chamar de cenas de alteridade radical. Tais cenas aparecem com muita frequência em seus escritos maduros, constituindo-se como um tipo de experimento de pensamento. Trata-se de cenas imaginárias que figuram encontros, perplexidades e incompreensões entre selvagens e civilizados, loucos e sãos, 
orientais e ocidentais, crianças e adultos, e assim por diante. Nesses experimentos, manifesta-se o rigor do trabalho crítico de Wittgenstein sobre a linguagem e o significado, sempre concomitante a sua crítica à metafísica.

Esta pesquisa se concentra especificamente no exame de cenas alteridade entre crianças (ou aprendizes, de maneira geral) e adultos, não só porque o recorte das cenas nos levou à constatação de que são estas as que aparecem com maior frequência na obra de Wittgenstein, mas sobretudo porque a infância pode ser entendida não apenas como um lugar específico dentro de uma cronologia, mas como um "lugar" que pode abrigar, em alguma medida, outras alteridades, pois o que interessa é ver as palavras em seu deslocamento, é a maneira como aprendemos a jogar com a linguagem e a maneira como essas alteridades podem nos fazer ver de onde vêm nossas certezas. Além disso, interessa bastante ver o modo como ensinamos/aprendemos, talvez porque aí se mostrem os acordos tácitos em uma forma de vida. Olhar com atenção para essas cenas tão familiares, mas tão poucas vezes pensadas com profundidade em nosso cotidiano, faz perceber, por exemplo, que o aprendiz de uma língua conta com uma série de outras coisas que não apenas as palavras: técnicas que se revelam nos gestos, nas expressões faciais de aprovação e desaprovação etc. Faz perceber também que tudo isso está ligado a regras que aos poucos internalizamos, ainda que nem sempre possamos explicitá-las. As cenas trazem ainda uma possibilidade de mostrar que a criança encontra no mundo uma ordem que é anterior a sua chegada - e que essa ordem não é "natural" ou "lógica". Com as técnicas disponibilizadas pelo adulto, a criança se familiariza com essa ordem. Mas esse aprendizado está baseado em regras que, inicialmente, não estão estabelecidas e é nesse momento, o da aprendizagem das regras, que podemos perceber algum "desconcerto": a alteridade torna-se aí o foco do olhar, no desconcerto. Todas as outras alteridades - loucos, estrangeiros, orientais, índios, negros etc. - compartilham desse "desconhecimento" da ordem prévia e das regras estabelecidas.

$\mathrm{Na}$ filosofia de Wittgenstein há um lugar para a alteridade (seja criança, louco, estrangeiro, oriental ou incivilizado) de onde é possível vê-la diferentemente do trivial, não como uma fraqueza ou uma desrazão relacionada, no caso da criança, a uma debilidade devida à pouca idade cronológica, mas como uma possível perspectiva apenas distinta daquela que está enraizada em nossas práticas; alteridade que, não estando sob total efeito do treino, se encontra, ainda, 
indiferente às regras, e é por isso mais capaz de mostrar o estranho com o qual convivemos, já que se lança mais facilmente ao experimento com a linguagem.

Não se trata, como se vê, de discutir cientificamente a aquisição da linguagem, mas de refletir sobre os modos como, enquanto a adquirimos, torna-se mais visível aquilo que sublinhamos neste trabalho, e que é anunciado por Wittgenstein: “imaginar uma linguagem é imaginar uma forma de vida” (PU $\S 19^{1}$ ). Percebemos, portanto, que Wittgenstein diverge da interpretação dominante sobre a alteridade infantil, normalmente invisível no que concerne às questões relacionadas ao pensamento, ao trazê-la, não mais como o pequeno adulto da cena agostiniana (PU §1), mas como alteridade capaz de expor a relação entre experiência e linguagem. Aqui essa consideração pela infância que sobressai nos escritos de Wittgenstein se entrelaça com umas reflexões do filósofo italiano Giorgio Agamben, apontadas pelo próprio pensador no prefácio à edição francesa da obra Infância e História:

\begin{abstract}
É significativo que justamente uma reflexão sobre a infância tenha conduzido o autor a uma pesquisa sobre a voz humana (ou sobre a sua ausência). A in-fância que está em questão no livro não é simplesmente um fato do qual seria possível isolar um lugar cronológico, nem algo como uma idade ou um estado psicossomático que uma psicologia ou uma paleontologia poderiam jamais construir como um fato humano independente da linguagem. (AGAMBEN, [1978] 2014: 10)
\end{abstract}

Percebemos, portanto, uma possibilidade de pensar não apenas o que a tradição estudiosa tem denominado infância - e essa possibilidade começa pela constatação de que infância e linguagem se entrelaçam de modo a se tornarem ideias estreitamente relacionadas, já que adquirimos a linguagem e dela nos apropriamos pouco a pouco, ao sermos introduzidos nas experiências da vida, ao agirmos com a linguagem. Por isso mesmo, as cenas de alteridade analisadas podem ser interessantes para o entendimento da expressão forma de vida.

Recusando, em benefício de uma compreensão perspectivista, tanto o universalismo como o relativismo na obra do filósofo austríaco, acreditamos ser esse olhar atento para as cenas de alteridade um movimento auspicioso na direção dessa compreensão. Por ser um trabalho que enfoca a difícil e elusiva noção de

\footnotetext{
${ }^{1}$ Nas citações de obras de Wittgenstein foram usadas as abreviações de praxe, listadas no início deste trabalho, juntamente com as edições traduzidas aqui utilizadas. São minhas todas as traduções sem outra indicação.
} 
forma de vida em Wittgenstein, não nos esquivamos também de um encontro com a antropologia - área que está reconhecidamente presente nos escritos do filósofo. Privilegiamos, nesse encontro, o trabalho etnofilosófico do antropólogo Eduardo Viveiros de Castro $(2002,2008)$.

$$
* * *
$$

As alteridades presentes na produção madura de Wittgenstein não só atestam a existência de partições ontológicas como também mostram a maneira como delas nos servimos para dar continuidade à forma de vida que tudo deseja classificar e teorizar, e que, por isso mesmo, guarda ilusões de verdade abrigadas na gramática (PU §241). Vejamos os seguintes exemplos de cenas de alteridade que aparecem nos escritos do filósofo:

Suponha-se que um adulto tinha dito a uma criança que estivera na Lua. A criança conta-me a história e eu digo que foi apenas uma brincadeira, o homem não tinha estado na Lua; ninguém esteve alguma vez na Lua; a Lua está muito longe e é impossível subir ou voar para lá. Se a criança insiste, dizendo que talvez haja um caminho para lá que eu não conheço, etc., que resposta lhe poderia dar? Que resposta poderia dar aos adultos de uma tribo que acreditam que há pessoas que vão às vezes à Lua (talvez seja assim que interpretam os seus sonhos) e que, na verdade, admitem que não há meios normais de subir ou voar para lá? - Mas uma criança, habitualmente, não fica presa a essa crença e depressa se convencerá com aquilo que the disser a sério (UG, §106).

Posso imaginar que Moore ${ }^{2}$ fosse capturado por uma tribo selvagem e que eles exprimissem a suspeita de que tivesse vindo de algum sítio entre a Terra e a Lua. Moore diz-lhe que sabe, etc., mas não pode indicar fundamentos para a sua certeza, porque eles têm ideias fantásticas sobre a aptidão do homem para o voo e não sabem nada de física. (UG, §264).

A loucura não deve olhar-se como uma doença. Por que motivo não se poderá ela olhar como uma mudança - mais ou menos repentina - de caráter? (VB: p. 84).

Nas três cenas apresentadas, está em cheque aquilo que consideramos ser uma certeza, normalmente fundamentada em argumentos lógicos calcados numa pretendida estabilidade dos significados que atingimos pela razão. Dessa forma, estão apartados da razão o selvagem, o louco e a criança e os aprendizes de um sistema de regras, em geral. Com essas cenas, Wittgenstein abre caminho para discussões de cunho epistemológico relacionadas, em última instância, à possibilidade de representação do mundo pelas sentenças da linguagem que

\footnotetext{
${ }^{2}$ George Edward MOORE (1873-1958) foi professor de Wittgenstein em Cambridge. Junto com Russell, é considerado co-fundador da filosofia analítica. Refutou o idealismo na filosofia e fez a defesa do pensamento realista. O último escrito de Wittgenstein, Da Certeza, é basicamente uma crítica ao empirismo defendido por Moore.
} 
guardam relação com as proposições lógicas. Ameaçadas essas relações, desmorona toda e qualquer pretensão de ancorar um fundamento último que ampare nossas certezas. Ainda uma vez relacionaremos esses pensamentos aos de Agamben, que, na mesma obra já citada, discorre sobre uma tarefa urgente do pensamento contemporâneo. Em suas palavras:

Uma das tarefas mais urgentes do pensamento contemporâneo é certamente a definição do conceito de transcendental em função de suas relações com a linguagem. Se é realmente verdade que Kant pôde articular o seu conceito de transcendental somente na medida em que omitiu o problema da linguagem, "transcendental" deve aqui indicar, alternativamente, uma experiência que se sustém somente na linguagem, um experimentum linguae no sentido próprio do termo, em que aquilo de que se tem experiência é a própria língua.

(...) É suficiente seguir com atenção o movimento do pensamento kantiano para dar-se conta de que o experimento da razão pura não pode ser outro senão um experimentum linguae, que se funda somente na possibilidade de nominar tais objetos transcendentais por meio do que Kant chama de "conceitos vazios sem objeto" (noúmeno, por exemplo), ou seja, como diria a linguística contemporânea, termos que não têm nenhuma referência (e que todavia conservam, escreve Kant, uma Bedeutung transcendental).

Um experimentum linguae deste tipo é a infância, na qual os limites da linguagem não são buscados fora da linguagem, na direção de sua referência, mas em uma experiência da linguagem como tal, na sua autorreferencialidade. (AGAMBEN, 2014:11, 12)

As cenas wittgensteinianas que criticam as certezas de Moore, parecem nos convidar ao experimentum linguae de que trata Agamben, na medida em que querem recuperar uma sabedoria anterior a esta que se molda em conformidade à ciência moderna, uma sabedoria livre da hýbris que impossibilita a experiência, no sentido que a antiguidade a entendia:

o problema central do conhecimento não é, para a antiguidade, o da relação entre um sujeito e um objeto, mas o da relação entre o uno e o múltiplo. Por isso o pensamento clássico não conhece um problema da experiência como tal; aquilo que se coloca, para nós, como problema da experiência, apresenta-se naturalmente, para ele, como problema da relação (da "partição", mas também da "diferença", como dirá Platão) entre o intelecto separado e os indivíduos em sua singularidade, entre o uno e o múltiplo, entre o inteligível e o sensível, entre o humano e o divino. E é esta diferença que o coro da Oréstia de Ésquilo sublinha, caracterizando - contra a hýbris de Agamenon - o saber humano como um páthei máthos, um aprender somente através de e após um sofrimento, que exclui toda possibilidade de prever, ou seja, de conhecer com certeza alguma coisa (AGAMBEN, 2014: 27).

Discussões de cunho epistemológico tiveram lugar sobretudo no último escrito de Wittgenstein, Da Certeza, obra que questiona fundamentalmente 
equívocos relacionados ao que seja uma crença e o que seja uma certeza: muitas das nossas "certezas", alerta Wittgenstein, são apenas condições relativamente permanentes que nos permitem compor um Weltbild (cosmovisão), garantindo a possibilidade de se jogar um mesmo jogo, pois qualquer um pressupõe um pano de fundo razoavelmente estável (GLOCK, 1998:76). Nas palavras de Prado Jr.:

Que é um Weltbild? Nós já o sabemos: é aquele amálgama de pseudoproposições cristalizado na base de um jogo de linguagem que, ao mesmo tempo, precede a alternativa entre o verdadeiro e o falso e abre o espaço para seu advento ou, numa palavra, o plano onde circulam e se entrechocam os conceitos. O senso comum nele se apoia espontaneamente e parece fazê-lo tomando-o como "verdade" (confundindo Weltbild e conhecimento dado) e não está completamente enganado, já que tal ilusão é necessária para o curso da vida cotidiana; a "filosofia do senso comum" não pode contar com esse álibi e se prolonga em empresas infelizes, como a de Moore, que termina por transformar o Weltbild em Weltanschauung ${ }^{3}$ (ou fundar o senso comum numa certeza racional) (PRADO Jr., 2004: 157).

Reconhecendo que crença e certeza são dois pilares da filosofia wittgensteiniana que funcionam, por assim dizer, como trilhas para ir ao encontro de um perspectivismo em sua filosofia, propomos uma análise de passagens do corpus wittgensteiniano que julgamos pertinentes a essas discussões propostas pelo filósofo.

Esse caminho trilhado por Wittgenstein concede um espaço em sua filosofia madura para uma epistemologia socializada, afirmando, em consequência, uma impossibilidade de que o conhecimento seja construído individualmente. Questiona, além disso, os reducionismos que se impõem quando nos deixamos ludibriar pela gramática. Glock comenta (p. 77-78) que "os fundamentos últimos de nosso conhecimento não são crenças, mas sim formas de comportamento", assertiva que nos traz de volta ao encontro da antropologia com a filosofia nos escritos maduros de Wittgenstein, o que, por sua vez, como se disse, redundou nas interpretações de uma filosofia de cunho relativista. Mas o que Wittgenstein propõe é o olhar de cima, a visão do voo, e não a comparação entre Weltbilder, como aponta Prado Jr.:

Um Weltbild, repitamos, é uma rede lançada no caos, que detém seu fluxo infinito, escolhendo e fixando alguns pontos que definem um plano, ou ainda, um estilo de vida. Mas há tantos Weltbilder quantos jogos de linguagem ou formas de vida; portanto, mil maneiras de cortar o caos ou desacelerar os movimentos que o atravessam. Haverá um Weltbild melhor do que outros?, poderíamos perguntar a

\footnotetext{
${ }^{3}$ Weltanschauung: visão de mundo.
} 
Wittgenstein (...). Mas sua resposta seria negativa, levando muitos de seus comentadores a atribuir-lhe equivocadamente alguma forma de relativismo (...) (PRADO Jr., 2004: 157-8).

No aforismo 6.41 do Tractatus encontramos: "O significado do mundo deve estar fora do mundo. No mundo tudo é como é, e acontece como acontece. Não há nele nenhum valor - e, se houvesse, não teria nenhum valor". A pergunta esclarecedora de Perloff (2008: 69) a respeito do aforismo é: "se 'o significado do mundo deve estar fora do mundo', o que estamos fazendo nós, medindo e avaliando o que está dentro?”. Pensar nessa pergunta nos leva não para uma defesa do relativismo na filosofia wittgensteiniana, mas para um entendimento de que há aí um "tom de irresolução", um "reconhecimento de um mistério que não pode ser resolvido" (Perloff, 2008: 69).

Nos ensaios publicados em 2004, Prado Jr. reivindica para Wittgenstein um lugar entre filósofos como Platão, Descartes ou Kant, não sendo ele "jamais o porta-voz do senso comum ou de qualquer forma de positivismo" (Prado Jr., 2004:13). Para assim o entender, alerta o pesquisador brasileiro, será preciso ler seus escritos da maturidade como uma continuidade importante do Tractatus, pois tanto a leitura isolada da primeira obra quanto a dos escritos da maturidade diminuem o alcance de sua filosofia. Somente a leitura da totalidade torna perceptível que essa continuação visa tão somente esclarecer nossos equívocos relacionados à linguagem (ou à gramática), tais equívocos redundando em questões epistemológicas, como esclarece Prado Jr.:

No capítulo (reconhecidamente subalterno) da epistemologia, com efeito, nada mudou com a implosão da ideia de forma lógica e da concepção, no fundo, representacional da linguagem. Já no Tractatus, o universalismo lógico era incapaz de conviver com alguma forma de pluralismo epistemológico: como o mostram as proposições relativas aos fundamentos da mecânica. Já lá a superstição moderna da "lei natural" ou do cientificismo era contraposta à sabedoria da mitologia antiga: ambas visões do mundo, como toda visão do mundo, não são nem verdadeiras nem falsas, são apenas visões do mundo; mas a mais arcaica não confunde princípios lógicos e regularidade natural e sabe, sobretudo, que é preciso parar em algum lugar, que não há fundamento absoluto. Se o primeiro Wittgenstein era, assim, capaz de guardar a sabedoria de seu mestre Hertz (sem incorrer nos excessos historicistas e relativistas que sua ideia de paradigma haveria de promover em tempos mais recentes), preservando a ideia da verdade da mecânica newtoniana, o segundo não dissolverá a verdade da ciência da natureza, pelo simples fato de reconhecer que a verdade da ciência se inscreve num chão pré-proposicional e précientífico, ou tolera mais de um sistema projetivo. (PRADO Jr., 2004:126) 
A crítica à dicotomização conceitual, cara ao universalismo tanto quanto ao relativismo, com a qual estamos habituados, sobretudo em ambientes escolares, vem sendo também empreendida em viés perspectivista na obra de outro importante pensador brasileiro que terá espaço considerável nesta pesquisa: o antropólogo Eduardo Viveiros de Castro (1996, 2002, 2002b, 2008). O pesquisador tem se dedicado ao que ele mesmo descreve como sendo uma "transcriação etnofilosófica do pensamento ameríndio" (Viveiros de Castro, 2008: 195). Como aponta Martins em artigo no qual o viés perspectivista das cenas ameríndias é aproximado ao fazer tradutório, ou seja, à linguagem, o perspectivismo que, com Viveiros de Castro podemos derivar do mundo ameríndio, apresenta alguma confluência e algumas diferenças importantes com relação aos perspectivismos que se manifestam na filosofia ocidental:

Começo observando que, entre os que leem as páginas antropológicas de Viveiros de Castro, não é raro que surja o impulso de "traduzir" de algum modo a vida ameríndia, a língua estranha que ele nos mostra, para as línguas virtuosas de, digamos, Nietzsche, Wittgenstein, Derrida, Deleuze, isso para citar apenas alguns dos nomes evocáveis.

Pelo modo como se desavêm com as nossas dicotomias tradicionais aparência/essência, natureza/cultura, sujeito/objeto, eu/outro, humano/não humano, nativo/estrangeiro, literal/metafórico e assim por diante -, as cenas ameríndias descritas e pensadas por Castro parecem de fato, surpreendentemente traduzíveis no linguajar daquelas filosofias, tão tenazmente empenhadas em afrontar e desconstruir a trama tensa e não raro opressora dos binarismos do Ocidente (MARTINS, 2012: 2).

A crítica radical ao pensamento dicotômico, como se disse, também aparece nos escritos maduros de Wittgenstein onde aprendemos que "desconfiar da gramática é o primeiro requisito para filosofar" (NB, p. 106), havendo aí, para começar, um inegável deslocamento do próprio conceito de gramática. O filósofo entendia que a forma gramatico-normativa das nossas proposições tem por trás delas a forma lógica, isto é, cumprem já uma exigência que é refratária à possibilidade de perspectivas.

Provocamos assim um diálogo entre a ideia de jogos de linguagem, de forma de vida - levando em conta seus panos de fundo, os Weltbilder que, reconhecidamente, estão na base do pensamento maduro de Wittgenstein - com a antropologia de Eduardo Viveiros de Castro, que, ao investigar a forma de vida ameríndia, como se disse, capta o que seria uma singular manifestação de 
perspectivismo - batizada pelo pensador brasileiro "perspectivismo ameríndio" que se opõe ao privilégio da objetivação encontrado na tradição ocidental em seus ideais de conhecimento:

(...) estamos diante de um ideal epistemológico que, longe de buscar reduzir a "intencionalidade ambiente" a zero, a fim de atingir uma representação absolutamente objetiva do mundo, toma a decisão oposta: o conhecimento verdadeiro visa à revelação de um máximo de intencionalidade, por via de um processo de "abdução da agência" sistemático e deliberado. Eu disse acima que o xamanismo era uma arte política. O que estou dizendo, agora, é que ele é uma arte política. Pois a boa interpretação xamânica é aquela que consegue ver cada evento como sendo, em verdade, uma ação, uma expressão de estados ou predicados intencionais de algum agente. $\mathrm{O}$ sucesso interpretativo é diretamente proporcional à ordem de intencionalidade que se consegue atribuir ao objeto ou noema. (VIVEIROS DE CASTRO, 2011: 359).

Visto sob o viés perspectivista para o qual aponta Wittgenstein, o significado tampouco se deixa reduzir e, além disso, só no jogo se deixa conhecer. Dessa constatação, surgem os problemas de pesquisa que este trabalho pretende analisar: o que podemos aprender com a filosofia da linguagem desenvolvida por Wittgenstein a partir desse encontro com a antropologia? Em que medida refletir sobre a alteridade adulto vs. criança pode nos ajudar a entender o quão contaminados estamos pela visão da linguagem como representação? Em que medida o exame das cenas wittgensteinianas de alteridade adulto vs. criança pode ser índice de um perspectivismo em seus escritos maduros?

1.1

\section{Objetivo}

Este trabalho identifica passagens dos escritos maduros de Wittgenstein em que se encenam situações de interação entre adultos e crianças, visando aprofundar a discussão sobre as relações entre linguagem e forma de vida. As ilustrações das cenas de alteridade adulto vs criança apresentadas apontam ainda para índices de uma filosofia perspectiva nos escritos do filósofo. 


\section{2}

\section{Metodologia}

A pesquisa parte, como se disse, da hipótese de uma continuidade entre as fases mais jovens e mais maduras da filosofia de Wittgenstein. O corpus específico provém, no entanto, de obras posteriores ao Tractatus, nas quais o procedimento de encenar situações de alteridade radical se intensifica. Incluem-se, em especial, as seguintes obras:

Observações filosóficas (1929-1930);

Livros castanho e azul (1933-1935);

Observações sobre os fundamentos da matemática (1937-44);

Cultura e valor (1945-51);

Fichas (1945-1948);

Investigações filosóficas (1936,37 e 1948-49);

Observações sobre a filosofia da psicologia (vols. 1 e 2; 1945-47);

Últimos escritos sobre a filosofia da psicologia (1948)

Da certeza (1951);

Observações sobre as cores (1951).

As passagens selecionadas foram ilustradas tendo vista as perguntas de pesquisa, os pontos de partida teóricos e o diálogo com a antropologia, conforme indicados na seção anterior.

O conceito de infância proposto por Agamben em sua obra Infância $e$ Linguagem também nos foi muito útil e por isso o trouxemos para este estudo, visando maiores esclarecimentos sobre um lugar de deslocamento do significado que se pode perceber não apenas a partir da fala da alteridade criança, mas também da alteridade "oriente", "loucura", "índio" e outras.

\section{3}

\section{Justificativa}

Leituras estanques dos escritos de Ludwig Wittgenstein não raramente o identificam ora como um universalista, ora como um relativista, mas parece haver, 
tanto numa posição quanto noutra, um equívoco, como aponta Prado Jr. É possível dizer que a maneira estanque de olhar para a produção do filósofo como um primeiro, um segundo e, até, mais recentemente, como um terceiro Wittgenstein, pode provir justamente do "embaçamento" que há nessa questão relacionada ao encontro da antropologia com a filosofia, disciplinas que por sua vez guardam relação direta com a linguagem e com o modo como tradicionalmente esta tem sido percebida. A crítica pós-moderna às dicotomias que regem a construção do conhecimento no Ocidente, notadamente a crítica encontrada nas páginas de Viveiros de Castro, aponta para um caminho que se julga promissor, mas até recentemente pouco explorado entre os estudiosos da linguagem. Wittgenstein oferece um corpus que o presente estudo julga, portanto, pertinente aproximar ao da antropologia.

Para além das relações entre linguagem, filosofia e antropologia em suas possibilidades de crítica a uma epistemologia que se baseia, antes de tudo, na dicotomia verdade vs. mito - e que, por isso mesmo, atribui à arte um lugar de menor importância que o lugar da ciência, por exemplo - este estudo enfoca também a infância em suas múltiplas possibilidades de interpretação, buscando ampliar a compreensão de questões tradicionalmente relacionadas ao campo da educação. 


\section{Wittgenstein: algumas noções relevantes}

"E representar uma linguagem significa representar-se uma forma de vida"

L. Wittgenstein, IF $\S 19$

As reflexões de Wittgenstein, como se sabe, desencadearam uma vasta produção de escritos secundários a elas, produção, aliás, em franca continuidade, cujos autores não cessam de reconhecer nessa filosofia o caráter inovador e fecundo de olhar a linguagem. Sua filosofia repercute, por esse motivo especialmente, entre muitos estudiosos, inspirando contribuições originais nas áreas das linguagens, da literatura, das artes em geral, como também dos estudos antropológicos e dos estudos relacionados à educação, dentre outras áreas do conhecimento que ainda poderiam ser citadas. Assim sendo, eleger os comentadores da literatura secundária à filosofia wittgensteiniana para compor este capítulo não foi uma tarefa tão evidente. Diante de tão vasta literatura, fez-se necessário distinguir quais pensadores representariam contribuições mais efetivas para a compreensão das repercussões dessa filosofia. Decidimos pela exegese canônica encontrada no Dicionário Wittgenstein de H. J. Glock e pelos vastos comentários de P. M. S. Hacker e G. P. Baker ${ }^{4}$ tão conhecidas entre os estudiosos da filosofia wittgensteiniana. Aparecem ainda nesses comentários, indo ao encontro do viés perspectivo para o qual aponta esta pesquisa, a literatura mais recentemente publicada sobre os escritos de Wittgenstein encontrada em Bento Prado Jr., Stanley Cavell, Marjorie Perloff e Gunter Gebauer, este último sobretudo pensando na ligação entre filosofia e antropologia em Wittgenstein e também por suas ideias que vão ao encontro do que propõe Prado Jr., uma leitura dos textos da maturidade de Wittgenstein como continuidade de uma filosofia única que aponta para o perspectivismo. Visando a uma possibilidade de diálogo entre todos esses autores para aprofundar o assunto em tela, encontramos também

\footnotetext{
${ }^{4}$ Comentadores de Wittgenstein cujo trabalho inicial remonta à década de 1970, anteriormente à publicação dos escritos mais tardios do filósofo. O trabalho desses autores é respeitado pela comunidade acadêmica não só pela profundidade e extensão de seus comentários às Investigações, como também pelo pioneirismo em relação à obra do Wittgenstein maduro. Trata-se de quatro volumes de extensos comentários; porém a obra aqui referenciada foi integralmente revisada apenas por Hacker nos anos de 2001-2002, quando Gordon Baker já havia falecido.
} 
uma leitura que nos serviu como guia na trilha percorrida: nesse caso, o artigo de Martins, Sobre a estabilidade do significado em Wittgenstein, que veio nos auxiliar a não perder de vista nossos objetivos - voltados para os estudos da linguagem - o que seria muito fácil se considerarmos que a filosofia de Wittgenstein abre tantos caminhos de diálogos com outras áreas. Procuramos, nesses comentadores, ainda que indiretamente, análises de passagens pertinentes ao corpus da pesquisa que, como vimos, trata do modo de filosofar de Wittgenstein, um permanente convite a perceber a alteridade por meio dos jogos de linguagem, o que, por si só, anuncia uma discussão cara ao perspectivismo.

O objetivo principal desta seção é o de indicar o modo como se tomam neste trabalho noções relevantes do pensamento de Wittgenstein, a partir dos comentadores já mencionados. Percorremos com eles, inicialmente a ideia de jogos de linguagem caminhando da exegese de Baker \& Hacker e de Glock para, como se disse, chegarmos a uma interpretação mais recente, encontrada em Cavell, Gebauer, Perloff, e Prado Jr. para com eles aprofundarmos no pensamento de Wittgenstein sobre a linguagem como forma de vida.

\section{1}

\section{Os jogos de linguagem}

A expressão jogos de linguagem, que remete, dentre outras coisas, a um conjunto de regras para o uso das palavras, começa a aparecer nos escritos de Wittgenstein no início dos anos 30 (GLOCK, 2008: 225; PERLOFF, 2008: 87; GEBAUER, 2013: 92). A expressão serve como uma analogia que, segundo Glock (1998: 226). surgiu em função da comparação entre sistemas axiomáticos e um jogo de xadrez. De acordo com Glock, tal analogia teve origem com os formalistas que consideravam a aritmética como um jogo realizado por meio de símbolos matemáticos, em que o significado de um símbolo matemático, ou de uma peça de xadrez, é a soma das regras que estabelecem os lances possíveis. Glock (1998: 225) destaca que, a partir de 1932, Wittgenstein estendeu a analogia do jogo à linguagem em sua totalidade, não apenas em sistemas axiomáticos, estabelecendo a linguagem como uma atividade regulamentada por normas de 
constituição (assim como no jogo). Nesse caso, as regras gramaticais ${ }^{5}$ : o significado de uma palavra é determinado pela norma que rege seu funcionamento. Gebauer defende, porém, que Wittgenstein faz também uma analogia com jogos de movimento, mesmo porque esses jogos delineiam mais adequadamente as descrições feitas em seus escritos tardios, quando os jogos de linguagem ganham uma posição central em sua filosofia:

\begin{abstract}
No entanto, ele não está pensando, como muitas vezes se supõe, no jogo de xadrez, mas num jogo de movimento. A indicação de Malcolm de que Wittgenstein chegou ao conceito de jogo de linguagem ao ver um jogo de futebol nunca foi levada em conta pela literatura. E se transferimos essa analogia para a descrição wittgensteiniana da linguagem - o que é facilmente possível - podemos conectar sistematicamente suas reflexões sobre a origem dos jogos de linguagem e sobre o aprendizado, sua concepção dos "eventos mentais" (intencionar, contar, pensar), sua discussão acerca da observância de regras, sua crítica a uma linguagem privada e a suposição de uma certeza dada com os jogos de linguagem. Muitos traços essenciais da filosofia mais tardia de Wittgenstein podem ser deduzidos de seu conceito de jogo (GEBAUER, 2013: 19).
\end{abstract}

É a partir das Investigações que Wittgenstein relaciona o jogo de linguagem aos seus usuários, método dividido por Baker \& Hacker em três diferentes enfoques: (a) o primeiro desses enfoques envolve justamente a criança bem pequena que por meio desse jogo - considerado pelo filósofo como um jogo primitivo (que vem primeiro) em relação ao jogo que se realiza mais tarde, quando adulta - desvenda o mundo. Quando chora ou grita, a criança é atendida pelos pais. Ao longo do tempo, ela compreende que a expressão oral pode substituir o choro ou grito e, visando obter os mesmos resultados que obtinha antes, ela substitui esses jogos ditos primitivos por outros mais elaborados; (b) o segundo enfoque salienta um jogo aparentemente ainda incompleto, onde há certa explicitação das razões sobre o motivo de algo ser expresso de uma determinada maneira. Além de aprofundar as raízes das assimilações, esse jogo permite realizar associações que podem ser esclarecedoras para outras expressões (Baker \& Hacker, 2005: 60). Wittgenstein, no § 244 de suas Investigações, se refere a essas associações ao falar da nomeação das sensações e explicar que ainda que as sensações sejam algo individualmente percebido, também são aprendidas

\footnotetext{
${ }^{5}$ A noção wittgensteiniana de gramática difere consideravelmente da noção corrente de gramática normativa pois, além de essa noção abarcar as regras gramático-normativas e/ou sintáticas, abarcam também explicações relacionadas ao significado de uma palavra e ao modo como usamos uma sentença. Assim, a "gramática" de uma palavra é também o seu significado (GLOCK, 19396).
} 
(treinadas nos jogos de linguagem), embora seja mais corriqueiro o aprendizado de nomes de objetos do que o nome das sensações. Um adulto ensina a uma criança que caiu e se machucou o nome daquilo que ela sente, dizendo-lhe propriamente "dor" ou mesmo derivações desta palavra, e, no futuro, a criança provavelmente irá verbalizar o que aconteceu, ao invés de somente gritar e chorar (Baker \& Hacker, 2009: 10). Os comentadores sublinham que o entendimento desses dois primeiros enfoques é importante para que se chegue a uma melhor compreensão dos jogos mais complexos:

These primitive language-games, which typically resemble fragments of our own language-games, illuminate our practices. For they reveal what complex concepts have a place in the description of our language, but not in the primitive context and they show why this is so. [...] They often isolate a feature analogous to some feature of our language, but which, surrounded by the ordinary circumstances of its use, is not easily brought to view (BAKER \& HACKER, 2005: 60).

Por último, há os jogos inventados por Wittgenstein, bastante semelhantes aos primitivos, mas que servem, na verdade, para demonstrar incoerências no interior da tese filosófica essencialista. Trata-se daquilo que o filósofo menciona como métodos por meio dos quais é possível descobrir essas incoerências (como no caso de cores e formas, conceitos atingidos apenas pela definição ostensiva ${ }^{6}$ ):

Somewhat differently (but as a natural extension of the second kind of case), Wittgenstein sometimes asks us to imagine primitive language-games played in fundamentally different circumstances from those in which we play ours. We are called upon to envisage a colour vocabulary that would be useful in a world in which almost all coloured objects have colours at the cold end of the spectrum, and which reds, oranges, and yellows occur only rarely and typically in combination and perhaps associated with a particular natural phenomenon (BAKER \& HACKER, 2005: 60-1).

É o gesto (ou a técnica) de mostrar que fundamenta, por assim dizer, os jogos de linguagem das designações das cores, legitimando assim um saber prático que, de outro modo, não é possível explicitar. O aprofundamento dessas reflexões dá lugar a uma discussão central no pensamento maduro de Wittgenstein sobre crença e certeza. A minuciosa observação do uso das palavras na linguagem corriqueira permitirá a crítica à metafísica de Moore, por exemplo - tema a ser

\footnotetext{
${ }^{6}$ Uma definição ostensiva é a explicação do significado de uma palavra por meio de enunciados como "Isto é um elefante" ou "Esta cor é o 'vermelho'." Inclui tipicamente três elementos: uma expressão demonstrativa, "Isto é...", "O nome disto é..."...."; um gesto dêitico (apontar); e uma amostra, o objeto para o qual se aponta (GLOCK,1998: 122).
} 
aprofundado mais adiante - que o trabalho com os jogos vai, aos poucos, elucidando ao permitir a reflexão sobre os significados.

Como vimos, portanto, originalmente os jogos de linguagem foram explicados como "modos de usar" signos mais simples do que aqueles utilizados na linguagem cotidiana, assim como "formas primitivas de linguagem" permitindo que as crianças comecem a usar as palavras (GLOCK, 1998: 226). Essa ideia, posteriormente, evolui para o conceito de jogo de linguagem como um sistema de comunicação que, de acordo com o parágrafo 7 das IF, é definido como o meio pelo qual as crianças aprendem sua língua materna.

Glock subdivide os jogos de linguagem wittgensteinianos em quatro classes, sendo elas: práticas de ensino, jogos de linguagem ficcionais, atividade linguísticas e linguagem como jogo. Em relação à primeira subdivisão, o autor mostra que, para Wittgenstein, os simples fatos de apontarmos para um objeto e dizer seu nome (como fazemos, por exemplo, para uma criança em processo de aquisição lexical) e também o de explicarmos o sentido de uma expressão (como é costume no caso do aprendizado de um estrangeiro) podem ser considerados jogos de linguagem simples. Um dos principais pontos que podem ser destacados nesta seção se relaciona ao posicionamento do filósofo quanto à ideia de que a faculdade da linguagem seria uma habilidade inata. Wittgenstein se posiciona contrariamente a tal ideia, ao afirmar que os jogos de linguagem funcionam como meios de explicar "os modos de se utilizar os signos" e mobilizam a linguagem como um "sistema de comunicação" desde sua forma mais primitiva. Outro ponto de destaque são as práticas de ensino que, segundo Glock, o filósofo não utiliza para sugerir hipóteses sobre as origens da prática linguística humana, mas sim como demonstrações dos diferentes fatores relacionados ao uso correto (sempre dependente de contexto) das expressões (GLOCK, 1998: 225-226).

Em relação aos jogos de linguagem ficcionais, eles são hipotéticos ou inventados, ou seja, não ocorrem efetivamente no cotidiano conversacional das línguas naturais, e têm como principal objetivo fazer com que os usos mais corriqueiros sejam levados em conta pelos que pensam a linguagem. De acordo com Glock, um dos modos de se criar um jogo de linguagem ficcional, expresso no Livro Castanho, é bastante semelhante ao da lógica e da filosofia formal: por meio de questionamentos sobre a verdade, as implicações e contradições entre uma ou mais sentenças, seria possível atingir certa profundidade reflexiva que 
possibilitaria, por sua vez, captar regras de funcionamento da linguagem. Conforme se disse anteriormente, Wittgenstein, principalmente a partir das Investigações, não se preocupará com questões sobre o funcionamento da linguagem, mas com o efeito que determinado modo de usá-la pode ocasionar. Outro modo de ocorrência de jogo de linguagem ficcional é uma espécie de reductio ad absurdum que aponta para o contraste entre os nossos efetivos jogos de linguagem e os conceitos filosóficos. Glock menciona o exemplo dado por Wittgenstein sobre os operários, que não elaboram sentenças longas e, muitas vezes, comunicam-se por meio de palavras isoladas ou expressões breves (IF § 2). Para Glock, essa passagem explicita a maneira encontrada por Wittgenstein para criticar algumas concepções de linguagem então em voga, já que, de acordo com essas concepções, aspectos como sentenças com estruturas sintáticas complexas, engajamento conversacional por tempo relativamente longo, bem como a resposta do que é considerado significativo e do que é tomado como nonsense, por meio das formas pelas quais acontecia a interação, seriam fundamentais para haver significação. Os jogos ficcionais, portanto, trazem ao centro do questionamento todos os pressupostos formalistas e lógicos sobre a linguagem, mostrando que, ainda que não seja complexa, uma conversação deve também ser tomada como um jogo regulado e efetivo, pois atinge sua finalidade prática (GLOCK, 1998: 226-227).

Acerca das atividades linguísticas, Glock afirma que se compõem de uma espécie de jogo de linguagem realista, isto é, ao contrário dos jogos ficcionais que anteriormente comentara, estes se evidenciam nas práticas conversacionais cotidianas, conforme pontua o próprio Wittgenstein (IF, §23). Mais comuns nos escritos posteriores às IF, nessa obra já é possível observar o início de uma maior abrangência da noção de jogo de linguagem sobre as atividades linguísticas: no mesmo 23 , o filósofo destaca práticas como dar ordens, descrever a aparência de um objeto, perguntar, prometer e construir ou imaginar um objeto a partir de sua descrição. É bastante interessante a reflexão apresentada por Glock de que Wittgenstein "não fornece um critério de identidade para jogos de linguagem". (GLOCK, 1998: 228).

Ligadas à confusão sobre o conceito de jogos de linguagem, Glock aponta para algumas objeções realizadas por alguns teóricos simpáticos às ideias de 
Wittgenstein, sobre a analogia wittgensteiniana da linguagem como jogo no caso do jogo de linguagem dos construtores:

É o modo como as atividades linguísticas se encontram interligadas com as nossas práticas não linguísticas, estando nelas imersas, que as torna mais importantes do que os jogos. As atividades linguísticas dos construtores são tão cruciais para suas vidas quanto são essenciais para as nossas a medição e o raciocínio indutivo. $\mathrm{O}$ jogo de linguagem da "dor" interliga-se com os modos que temos de verificar atribuições de dor a terceiros, mas também com a comiseração etc. Nossos jogos de linguagem estão imersos em nossa forma de vida, as práticas gerais de uma comunidade linguística. Em virtude dessa vinculação com a prática, jogos com palavras como palavras cruzadas não contariam como jogos de linguagem para Wittgenstein (GLOCK, 1998: 229).

As atividades linguísticas estão, portanto ligadas a fatores externos à linguagem, isto é, dão destaque aos efeitos práticos delas decorrentes. Glock mostra também que, para Wittgenstein, pelo fato de os jogos serem autônomos, cada um deles possui uma regra particular de funcionamento que é validada (ou não) pelos falantes, isto é, ainda que não possua efeitos práticos, o jogo de linguagem se liga à realidade, pois leva em conta as convenções da prática cotidiana. Glock ainda mostra que muito daquilo que se considera como atividades são, em verdade, formalidades ou protocolos vazios de sentidos efetivos. Reside nessa questão, segundo ele, a maior parte das confusões que se realiza com a obra de Wittgenstein (GLOCK, 1998: 228). Glock, ainda que não relacione diretamente o pensamento do filósofo com a antropologia, observa que:

Embora tenha continuado a afirmar que, para compreendermos nossos conceitos, "nada" é mais importante do que a construção de conceitos fictícios (LW I §19), Wittgenstein passa a fazer um uso menos frequente de jogos de linguagem fictícios depois das Investigações. Passa, em vez disso, a enfocar mais de perto as atividades linguísticas reais, descrevendo-as contra o pano de fundo de nossas práticas não linguísticas. (GLOCK, 1998: 228)

A última classe na tipologia de Glock, que se refere à linguagem como um jogo, corrobora com sua argumentação a respeito da seriedade e da relevância dos jogos de linguagem, conforme foi mencionado no parágrafo anterior. Glock ressalta, no entanto, que a analogia da linguagem com o jogo pode estar estremecida e isso ocorre no ponto em que as nossas práticas linguísticas, sendo inter-relacionadas (ordenar e obedecer, por exemplo), fazem parte de um sistema global. Para descrever tal ideia, Wittgenstein - em sintonia com Boltzmann e Mauthner - lança mão de outra analogia: os fragmentos de nossa prática 
linguística são como as ruas de uma cidade, sendo o centro constituído pela linguagem do cotidiano, enquanto que os subúrbios, suas linhas retas e uniformes seriam formados por novas contribuições lexicais e semânticas das ciências, como as da química e as da matemática (IF § 18). Wittgenstein emprega então o termo "jogos de linguagem" para se referir a esse sistema como um todo e assim "ele apresenta sua ideia mais importante: 'Chamarei também jogo de linguagem o conjunto da linguagem e das atividades com as quais está interligada' (PI §7)” (2008: 229). Glock sustenta que o filósofo somente considera os usos das palavras em contexto real, diante das necessidades e dos desejos comunicativos, o que dá à expressão jogos de linguagem de Wittgenstein uma seriedade maior em relação a outros usos que se faz dela em geral. Em relação às considerações sobre linguagem (e também sobre os jogos de linguagem) realizadas incialmente, vê-se que, "enquanto, no princípio, as palavras possuem significado dentro de uma proposição no interior dos jogos em que elas são utilizadas, mais tarde ele nos diz que 'as palavras só possuem significado no fluxo da vida' (LW I §913)” (1998: 229), o que nos leva a pensar num encontro dos escritos maduros de Wittgenstein com a antropologia. Os jogos de linguagem, porém, ainda que autônomos, não configuram uma "forma de vida", embora sejam ideias correlatas.

A exegese de Baker \& Hacker argumenta também que os jogos dispõem de um conjunto de diretrizes, conjugadas segundo o propósito filosófico de cada um deles. De modo resumido, pode-se afirmar que eles explicitam diretrizes por meio da seguinte ordenação (BAKER \& HACKER, 2005: 61-2):

a) palavras que devem seguir modelos combinatórios para formar (ou não) sentenças;

b) instrumentos (por exemplo, gestos, modelos e figuras): servem como marcadores do contexto paralinguístico, geralmente ignorados por linguistas e filósofos;

c) contexto: do mesmo modo que há regras na execução de um jogo real, o uso da linguagem requer algumas regras e também o trabalho com certas contingências que revelam um acordo entre os participantes de um mesmo jogo. Para melhor explicitar, cita-se:

These may be very general features of the natural world, e.g. the rigidity and nonelasticity of material objects and of measuring rods, and equally general features of humanity, e.g. agreement in responses (to injury, colour, pointing, etc.). They 
may, however, involve more specific features, peculiar to a very particular language-game of, say, a small linguistic group, e.g. interests and values (Zettel 380), special activities such as battles (Philosophical Investigations $§ 19$ ), building (Philosophical Investigations § 2), contests (The Blue and Brown Books § 110), as well as availability of particular types of object (e.g. building-stones, colour samples, etc.) (BAKER \& HACKER, 2005: 61-2, grifo nosso);

d) uso, propósito, papel e função dos instrumentos, palavras e sentenças: Wittgenstein atribuía à ausência de preocupação quanto ao uso da parte dos filósofos essencialistas o maior erro de análise (dariam maior atenção à forma do que ao uso feito das expressões);

e) aprendizado: uma das razões para a boa execução dos jogos de linguagem é o treino, ou seja, todos são treinados a jogar com a linguagem e, para Wittgenstein, existem diferentes tipos de aprendizado quanto à linguagem (memorização de palavras, memorização da sequência de números, aprender a realizar a comparação de aspectos, bem como a aplicação de modelos distintivos, como, por exemplo, ao se falar nos nomes das cores, nos números, em nomes de objetos materiais, etc.).

Como o foco principal deste trabalho se dá nas relações de alteridade entre adulto e criança, é preciso destacar alguns comentários de Baker \& Hacker relacionados ao aprendizado que possam ajudar na compreensão desse enfoque. Nos $§ 186$ e $187^{7}$ das Investigações, Wittgenstein trata da intuição, isto é, de "uma nova compreensão" em relação ao desenvolvimento dos saberes, que requer certo

\footnotetext{
7 "Do que você diz, decorre pois que uma nova compreensão - a intuição - é indispensável, em cada nível, para executar a ordem ' +n' corretamente”. - Para executá-la corretamente! Como se decide então qual é o passo correto em um ponto determinado? - "O passo correto é aquele que se conforma à ordem - como foi significada (gemeint)." - Assim, quando você deu a ordem "+2", você quis dizer que o aluno devia escrever 1002 após 1000 - e quis dizer também que ele devia escrever 1868 depois de 1866 e 100036 após 100034, e assim por diante - um número infinito de tais frases? - "Não: o que eu quis dizer é que ele devia escrever, após cada número já escrito, o segundo número seguinte; e a partir daí, todas aquelas frases decorrem da sua posição." - Mas é justamente aí que está a questão: a saber, o que, num ponto qualquer, decorre dessa frase. Ou, também, o que devemos chamar, num ponto qualquer, de "conformidade" com aquela frase (e também com o sentido (Meinung) que você, naquela ocasião deu à frase - não importa em que tenha consistido). Mais correto do que dizer que em cada ponto é necessário uma intuição, seria quase dizer: é necessário em cada ponto uma nova decisão.

"Eu já sabia também, naquela ocasião em que dei a ordem, que ele deveria escrever 1002 após 1000 !" Certamente; e você pode até afirmar que quis dizer isso na ocasião; apenas você não se deve deixar enganar pela gramática das palavras "saber" e "querer dizer". Pois você não quer dizer que pensara, na ocasião, na passagem de 1000 a 1002 - e, se pensara nessa passagem, não pensara em outra. Se "eu já sabia naquela ocasião..." significa algo como: "se alguém me tivesse perguntado naquela ocasião que número deveria escrever após 1000, eu teria respondido '1002'”. Não duvido disso. É uma suposição da mesma espécie desta: "se ele naquela ocasião tivesse caído na água eu teria saltado atrás dele". - Em que consistia então o errôneo de sua ideia? (IF, §§ 186,87).
} 
acúmulo de experiências para ser utilizada; afinal só é possível julgar se algo está caminhando na direção correta se o objetivo desejado for conhecido ou, pelo menos, se aquele que trilha o caminho vislumbrar onde quer chegar. Baker \& Hacker observam que, pelo fato de a criança ainda não possuir os critérios de correção que lhe permitam esse vislumbre, ela procura alcançar o que foi demandado pelo modo como lhe foi explicado ou exemplificado (Baker \& Hacker, 2009: 71). Assim, a fala do professor possui para a criança um caráter instrutivo e, conforme foi visto anteriormente, Wittgenstein afirma que o objetivo do ensino não é um procedimento padrão do aluno, mas sim o treino do comportamento que faça o aluno seguir regras e aplicá-las corretamente. Para melhor exemplificar essa noção, pode-se mencionar a passagem da obra de Baker \& Hacker em que comentam um trecho das Investigações, quando Wittgenstein trata de um lugar comum entre professores e aprendizes:

\begin{abstract}
We are inclined, in our explanations to a learner, to say with exasperation, 'But surely you can see ...' (cf. §185). This exclamation seems to express the thought that knowing how to continue a series is a matter of seeing a pattern in it ( $\$ 228)$, a pattern which gives us everything, and which we merely have to follow. Consequently, somebody who errs will be upbraided for failure to see something in plain view. This accusation will be lodged by a teacher who is 'compelled by a rule', who understands that the rule leaves no room for choices, and who follows the rule with complete assurance because he sees the pattern it presents. (BAKER \& HACKER, 2009: 205)
\end{abstract}

f) ensino: no jogo interativo da linguagem, o contexto e o método pelos quais se realiza o ensino podem elucidar padrões de questionamentos, respostas, bem como os critérios pelos quais algo pode ser caracterizado ou explicado.

De modo semelhante ao que se falou no subitem anterior, sobre os $\S \S 186 \mathrm{e}$ 187, que tratam da compreensão da criança sobre o que o professor ou adulto desejou significar quanto à postura docente em relação ao aluno e às expectativas do que ela gera para o ensino, de que Wittgenstein trata no $\S 191$ das Investigações, Baker \& Hacker explicam que há uma ilusão de automatização, como se uma regra descrita pelo professor fosse capaz de prever todos os passos a serem dados pelos alunos.

[...] The illusion that a machine predetermines its movements in advance, that it 'has it in it' to move just thus, is parallel to the thought that the general formula of a rule contains in advance the steps to be taken, and to the idea that 'I meant him to go on thus' signifies that the steps to be taken have already been taken in some sense in the mind of the teacher (cf. MS 118 ( Vol. XIV), 95v-96r). Hence also, it 
illuminates the confusions involved in the supposition that what we 'grasp in a flash' is something from which the use unfolds. [...] This machine analogy is particularly apt here. For we are prone to view a rule as determining a result in the manner of a super-machine, rather than as determining a form of description (BAKER \& HACKER, 2009: 107).

Mais adiante, os autores irão continuar a reflexão em torno do ensino e também do treinamento dos alunos. De acordo com Baker \& Hacker, na obra Remarks on the Foundations of Mathematics, Wittgenstein afirma que o aluno comprova o entendimento de uma regra somente se reage de uma determinada maneira a sua aplicação. Wittgenstein diz, no entanto, que a reação a uma regra não se dá sempre da mesma forma, já que as circunstâncias do ambiente devem ser levadas em conta na apreciação dos resultados obtidos de sua aplicação. Isto é, da mesma maneira que um locutor não tem consciência das propriedades regulares que segue quando fala, um aluno não necessita estar completamente ciente dos processos de encadeamento advindos de uma regra lógica, ele não necessariamente conhece os pormenores que o levam a reagir de uma determinada maneira (Baker \& Hacker, 2009: 120).

g) prática: quanto mais um jogo de linguagem é executado, mais aprimorado pode se tornar o jogador, afinal, a prática pode lhe mostrar a natureza das regras a serem seguidas, bem como o meio pelo qual o aparente descompasso entre elas e suas aplicações pode ser superado;

h) as atividades do jogo: a concentração sobre as regras de uso nas/entre as expressões permite maior clareza sobre a diversidade dos símbolos linguísticos, enfatiza o contexto normal em que são usados, seus propósitos normais ou extraordinários, bem como as justificativas para uma ou outra ocorrência; e

i) completude: de acordo com o próprio Wittgenstein, os jogos de linguagem inventados que propõe não devem ser considerados como fragmentos, mas sim em sua integridade, pelo menos, como parte de um todo onde esse todo está também representado.

Os aspectos apontados por Baker \& Hacker (2005: 61-2) em torno dos jogos de linguagem inventados (como existem em algumas obras do filósofo, e também em uma aula comum de língua ou ainda em um exercício de lógica) não podem ser tomados como fundamentais ou constitutivos de todo jogo desse tipo, mas sim como indícios do que pode formá-los vez ou outra. É interessante notar ainda que, a despeito de estarem circunscritos a essa modalidade, alguns dos aspectos 
apontados muitas vezes pertencem também aos chamados jogos de linguagem naturais, assunto tratado a seguir.

Em relação a essa modalidade, Wittgenstein prevê uma ampla gama de experiências cotidianas, já que é o uso (e não a finalidade, apesar de esta ser discutível tanto para o inventado quanto para o natural) o que a caracteriza. Assim, ele sugere três categorias a fim de compreender os jogos inscritos como naturais: a primeira delas se refere às palavras, à atribuição de sentidos, na vida cotidiana, que não são reconhecidos como legítimos por lexicógrafos, como no caso das extensões de sentido para "jogo", "proposta", "linguagem", "pensar", "mundo", “dor", "ler"; a segunda categoria está ligada aos atos linguísticos e atividades, por exemplo, mentir, contar, dar ordens ou obedecê-las, descrever um objeto ou dar suas medidas, noticiar um evento, contar um sonho, enfim quase a totalidade das relações comunicativas é realizada por meio de determinadas convenções e tem usos característicos; a terceira e última categoria é aquela referente a usos acadêmicos, científicos ou filosóficos tidos como de maior complexidade, mas que não são atos em si e não possuem um fim comunicativo explícito, como, por exemplo, construir um objeto a partir de uma descrição oral, elaborar e testar hipóteses, apresentar resultados de experimentos em uma tabela ou gráfico, intuir resultados ou ainda realizar testes com objetos concretos com a finalidade de obter impressões, etc. (Baker \& Hacker, 2005: 63).

Conforme apontado, as características tidas como típicas dos jogos inventados podem também ser observadas nos naturais. Isso se torna mais evidente se considerarmos que as habilidades mencionadas (principalmente no caso do contexto, dos instrumentos e do propósito) entram em cena nos diversos usos que se faz da linguagem cotidiana, ainda que, por serem extremamente habituais, não sejam percebidas enquanto habilidades em si. Baker \& Hacker falam a respeito dessa circunstância e apontam que, com exceção da completude, quase todas essas habilidades podem ser vistas nos jogos de linguagem naturais (BAKER \& HACKER, 2005: 63).

No segundo volume de Wittgenstein rules, grammar and necessity, algumas ideias do filósofo em torno da noção postulada no Brown Book e trabalhada em parte das Investigações Filosóficas são discutidas com maior detalhamento. Em relação ao item (c) mostrado anteriormente, ou seja, ao acordo (agreement Übereinstimmung) como característica dos jogos, Baker \& Hacker dizem que ele 
deve ser expandido a três eixos do pensamento wittgensteiniano, para que possa ser compreendido. Em primeiro lugar, deve haver um acordo entre uma regra e sua aplicação, tendo este pressuposto surgido nos primeiros trabalhos de Wittgenstein, ainda de cunho lógico, e se mantido nas últimas obras. Segundo ele, uma regra que permite correta explicação de uma determinada expressão é parâmetro para seu uso (Baker \& Hacker, 1985: 229). Daí o fato de ser possível arbitrar sobre a correção do uso de uma expressão no interior de uma fala, de acordo com este ou aquele objetivo.

O segundo ponto que deve ser esclarecido quanto a esse acordo é o de que as regras e conceitos só se referem ao mundo porque ele é de uma determinada maneira e, caso fosse diferente, isso não significaria que as regras estivessem erradas, mas simplesmente que não teriam serventia. É por conta da estabilidade do mundo "natural" que regras e conceitos podem ser estabelecidos. Apesar de parecer banal, este é um ponto de inflexão na crítica wittgensteiniana em relação às teorias lógico-filosóficas:

These background constancies of the natural world and our interaction with it are not component elements of our concepts, i.e. not parts of the explanations of them. It is part of the framework within our language-games are played, not part of the games themselves. [...] We labour under the illusion that the conditions under which we employ concepts are written into the concepts, that the pictures of our language-games includes the frame. [...] And this is erroneous (BAKER \& HACKER, 1985: 229-30).

Nota-se que as explicações de Baker \& Hacker, nesse trecho, possuem ligações não apenas com o item (c), contexto, mas também com os itens (e) aprendizado e (f) ensino, expostos anteriormente. Isso porque, em relação ao ensino e ao aprendizado, os autores mostram que as explicações e os jogos de linguagens são propostos e compreendidos contra o pano de fundo da estabilidade dos objetos no mundo, porém esse mesmo pano de fundo não está incluído na explicação. Os autores dão o exemplo de vermelho: professores não dizem que algo é vermelho sob certas condições, no entanto a luz e a capacidade de enxergar cores são itens pressupostos e implícitos na explicação (ou, como se aplica melhor para esse caso, na definição ostensiva) do que é esta cor. Ainda outro item recai no interior dessa consideração sobre o acordo, aquele $(\mathrm{g})$, que se refere à prática de aperfeiçoamento no jogo, ligando-se às condições mais ou menos ordinárias de 
uma expressão, que podem tornar duvidosas suas regras de utilização. Os autores explicam:

[...] Mastery of a language-game involves the ability to explain (if only by paradigmatic exemplification) how it is to be played. [...] The rules governing a technique in general, the explanations of word-meanings in particular, do not incorporate specifications of the normal conditions in which they apply. [...] If in deviant (perhaps only imaginable) circumstances what we ordinarily give and accept as correct explanations of the meaning of a word do not suffice to settle whether it is applicable, then its application in those conditions is undetermined. [...] There is nothing to be discovered here about what the expression really means, but rather a fresh stipulation would be necessary (BAKER \& HACKER, 1985: 230).

O terceiro eixo de que tratam Baker \& Hacker é o do acordo entre os participantes envolvidos em um jogo de linguagem, sendo este o primeiro a ser acessado pelos leitores quando Wittgenstein fala a respeito do acordo como uma das características dos jogos de linguagem. Ele diz respeito, sem dúvida, a todos os itens aqui tratados e é direcionado, mais especificamente, aos consensos entre julgamentos, definições, aplicabilidade de regras, aceitação e ratificação de provas e em resultados de cálculos. São, portanto, os materiais básicos pelos quais uma interação pode ser iniciada e que possibilitam obtenção de efeitos na linguagem, sendo chamados por Wittgenstein de "formas de vida". É interessante notar que Wittgenstein afirma (Wittgenstein's Lectures on The Foundation of Mathematics 183f, 1939, apud Baker \& Hacker, 1985: 232), contrariamente às concepções lógico-filosóficas em voga na época, que esses consensos não advêm de verdades constatadas com cálculos e análises, mas sim que surgem "na ação", ou seja, no uso efetivo da linguagem pelos jogadores (BAKER \& HACKER, 1985: 232).

Gebauer, a respeito da evolução do pensamento wittgensteiniano que vai de sua concepção de gramática aos jogos de linguagem, observa que o conceito de regra, sozinho, não dá conta da conexão entre signo e vida:

Numa série de observações, Wittgenstein começa a partir de 1930 a ligar o conceito de regra ao de jogo. Inicialmente as referências ao jogo aparecem mais em modos de uso metafóricos e servem, ao que parece, para apoiar o conceito de gramática. Com o passar do tempo, no entanto, o conceito de jogo é empregado cada vez mais no sentido literal. Numa observação da Gramática filosófica, Wittgenstein passa diretamente da caracterização da linguagem como cálculo, que é aparentada com seu conceito de gramática, para uma concepção da linguagem baseada na ação: "A linguagem é para nós um cálculo; ela é caracterizada por ações linguísticas” (PG, p. 193). (GEBAUER, 2013: 93). 
Com as observações de Gebauer sobre as mudanças a respeito da importância das regras no pensamento de Wittgenstein, chega-se a um ponto crucial para a relação dos jogos com o fluxo da vida: a questão da temporalidade que ganha novo valor na obra madura do filósofo.

Com o conceito de jogo de linguagem surge uma concepção de regra diferente daquela que Wittgenstein tinha em mente com a conexão do uso linguístico a uma gramática. Ela tem, diferentemente da concepção de gramática, uma nítida referência temporal, na medida em que jogos formam unidades temporais com começo e fim. Jogos de linguagem são episódios no processo da vida, ao qual eles dão estrutura, forma e direção. Com a elaboração de seu novo conceito, Wittgenstein incorpora em seu pensamento a dinâmica da linguagem que se desdobra temporalmente. [...] O surgimento de um jogo de linguagem a partir do processo da vida significa uma ruptura com o tempo da práxis: um início, um novo evento e um fim; é um produto com um tempo próprio (GEBAUER, 2013: 94).

As regras, entendidas assim, emergindo na ação, dão nova compreensão à concepção do significado, este que está no centro das disputas filosóficas. As próprias regras não são fixas, como talvez quiséssemos que fossem: "a regra do jogo não é o que está na lista de regras; o que ela de fato é decide-se no jogo. Não há garantia de que uma palavra usada assim agora terá o mesmo significado quando utilizada novamente" (GEBAUER, 2013: 96). Assim podemos dizer com Martins que Wittgenstein realiza um plano bastante mais amplo do que simplesmente fazer filosofia da linguagem. Seu trabalho caminha para desvelar

o equívoco fundamental de uma certa empreitada intelectual humana, a saber, a especulação filosófica sobre o que as coisas são, a busca da determinação de suas essências. Como esta empreitada se assenta sobre o lastro de uma sólida tradição, parte do esforço de Wittgenstein consiste em esclarecer que, a despeito da qualidade do lastro, o barco, por assim dizer, não vai a parte alguma. (MARTINS, 2009: 21).

O caminho de Wittgenstein é, claramente, o de subverter uma visão da linguagem que está subjacente às teorias filosóficas essencialistas (MARTINS, 2013: 26). As cenas de ensino que mais adiante vamos esmiuçar serão fundamentais para dar vida a sua crítica à linguagem como um cálculo mental.

Uma adequada leitura dos jogos de linguagem, no entanto, passa pelo cuidado em não exagerar sua dimensão cognitiva (PRADO Jr., 2004: 31), já que tal exagero poderia instituir, contra a letra e o espírito da obra madura de Wittgenstein, "uma espécie de jogo de linguagem ideal e final, que atrapalha a compreensão da obra de Wittgenstein e do próprio mundo" (p. 38). 
A pressa em teorizar e demarcar o que venha a ser um jogo de linguagem pode levar à desatenção quanto à própria maneira de trabalhar do filósofo que, contrariando a pressa, tendia a uma necessária "ruminação", sempre insistindo sobre a dificuldade essencial da expressão. Prado Jr. alerta sobre a necessidade de uma interpretação capaz de ver uma incompletude essencial ao pensamento de Wittgenstein, incompletude que é dificilmente reconhecida por seus comentadores e que prejudica fortemente a compreensão de seus escritos (p. 40). A má compreensão, de acordo com Prado Jr., leva tanto adversários quanto advogados do relativismo a desencavar teses que os textos de Wittgenstein, se lidos com atenção, desautorizam. Assim, Prado Jr. ressalta que o simples reconhecimento de que, "ao descrever e compreender o funcionamento de um jogo de linguagem, eu, de alguma maneira, estou qualificado a compreender todos os jogos de linguagem, reais ou possíveis" (PRADO Jr. 2004: 43) basta para salvar Wittgenstein do relativismo tão em voga na pós-modernidade. A confusão que a má compreensão do que vêm a ser jogos de linguagem pode causar em relação às questões epistemológicas na filosofia wittgensteiniana parece residir na difícil harmonia entre a compreensão do jogo de linguagem e a irredutibilidade dos Weltbilder ou dos abismos que separam diferentes paradigmas. O abismo, continua Prado Jr., "reside mais nas crenças (infundadas ou infundáveis) cristalizadas na mitologia de base dos jogos de linguagem, do que nos "princípios fundamentais da pesquisa humana" (UG §670). Em sua defesa do não relativismo na obra wittgensteiniana, Prado Jr. pontua:

Trata-se (os princípios fundamentais) de algo puramente formal, que nada prejulga da constituição ontológica do mundo; no limite: (a) a ideia de que toda proposição significativa depende de um fundamento ou de um método de verificação; (b) que toda fundamentação tem um limite, justamente uma base em si mesma infundada; e (c) que esse espaço, aparentemente estreito, uma esfera bien aménagée internamente, flutuando sobre um abismo sem fundo, é suficientemente largo para abrigar o funcionamento do entendimento humano. (Prado Jr., 2004:44).

Esta é, portanto, uma filosofia orientada sobretudo para uma visão sinóptica $^{8}$ não apenas do jogos de linguagem, mas também das formas de vida

\footnotetext{
${ }^{8}$ Wittgenstein faz uso da expressão Übersicht que, segundo Glock (1998: 374) foi traduzida como "visão geral" ou "visão global". Tais traduções, aponta Glock, contribuem para mascarar a penetrabilidade e a importância desse conceito na obra do filósofo. A respeito dessa penetrabilidade, Prado Jr. (2004: 123) comenta que o "método" goetheano herdado por Wittgenstein "implica a ideia de uma visão sinóptica, de sobrevoo, que identifica semelhanças e diferenças". Tal método "etnológico ou sinóptico", continua Prado Jr., "neutraliza o relativismo
} 
neles reveladas, de modo que julgamentos a partir de pretensas fundamentações estão absolutamente desconvidadas.

\subsection{1}

\section{Os jogos de linguagem e o ensino ostensivo}

Uma cena de alteridade adulto vs criança, como sabemos, inaugura as Investigações. Trata-se de uma cena importada das Confissões de Agostinho", referindo-se às memórias sobre o aprendizado da língua materna. Wittgenstein aponta que nas palavras de Agostinho existe uma determinada imagem de linguagem como representação, a saber: as palavras da linguagem denominam objetos e as frases são ligações dessas denominações (IF § 1). Nos segmentos seguintes, Wittgenstein realiza uma crítica à visão agostiniana da linguagem, ao afirmar que, embora haja uma descrição de um sistema de comunicação, esse sistema não dá conta da complexidade de nossas práticas em linguagem (IF § 3).

Diferentemente do que possa parecer, não é uma mera oposição a Agostinho ou à sua filosofia que leva Wittgenstein a eleger tal cena, mas antes, o reconhecimento de que a cena ilustra com precisão as questões do significado de acordo com a tradição filosófica ocidental. Por sua importância, pode, por meio dela, desfazer confusões, já que guarda uma imagem do "ensino ostensivo das palavras" que ajudará a esclarecer as consequências de se tomar o jogo primitivo da ostensão e replicá-lo em pretensões da metafísica. O filósofo percebe, de fato, que concepções filosóficas a respeito do significado são, por assim dizer, gestadas a partir de uma ideia de linguagem como representação do mundo e que a cena agostiniana se presta a mostrar os embaraços em que nos enredamos quando trilhamos esse caminho, estando as análises lógicas propostas por Russel, Frege e

sem pagar o preço do dogmatismo ou do universalismo clássicos" ao retirar da avaliação (ou comparação) feita "todo e qualquer peso epistemológico ou teórico".

${ }^{9}$ SANTO AGOSTINHO, nas Confissões, I/8: Se os adultos nomeassem algum objeto e, ao fazê-lo, se voltassem para ele, eu percebia isso e compreendia que o objeto fora designado pelos sons que eles pronunciavam, pois eles queriam indicá-lo. Mas deduzi isto dos seus gestos, a linguagem natural de todos os povos, e da linguagem que, por meio da mímica e dos jogos com os olhos, por meio dos movimentos dos membros e do som da voz, indica as sensações da alma, quando esta deseja algo, ou se detém, ou recusa ou foge. Assim, aprendi pouco a pouco a compreender quais coisas eram designadas pelas palavras que eu ouvia pronunciar repetidamente nos seus lugares determinados em frases diferentes. E quando habituara minha boca a esses signos, dava expressão a meus desejos. (IF, § 1) 
pelo próprio Wittgenstein no Tractatus contaminadas pela visão platônica que pressupõe uma essência das coisas que os nomes representam, sendo, nessa concepção, a linguagem uma ligação dessa essência à coisa. De acordo com essa visão, a garantia de haver comunicação se dá por meio de algo "misterioso" que atua entre quem fala e quem ouve, de modo que a parte física (a palavra falada ou escrita) desperte no interlocutor a mesma impressão, o mesmo significado. A nova maneira de pensar a linguagem trazida por Wittgenstein exclui o pensamento essencialista, sempre claudicante quando se trata de explicar a ligação entre a palavra e sua essência, para assumir uma compreensão prática:

Onde antes se assumiam atos mentais, há em Wittgenstein ações práticas que ocorrem no jogo de linguagem formado coletivamente. Na visão de Wittgenstein, a ordem que Agostinho supõe dada por Deus é produzida na atividade de uma comunidade linguística (GEBAUER, 2013:13).

Os jogos de linguagem primitivos, como o jogo da ostensão, são a base do aprendizado, pois têm a função de preparar para os jogos subsequentes, assim como o uso de um signo prepara para outros usos desse mesmo signo. Nas diversas cenas de alteridade adulto vs criança que constam nas Investigações, há outro exemplo, como a cena de um adulto que aponta para um objeto de determinada cor e diz para a criança: “isto é vermelho" e, então, a criança corresponde ao jogo de mostrar, apontando, em seguida, para uma série de objetos de cor vermelha. Esse caso difere do exemplo anterior, pois o gesto não guarda relação óbvia com o significado da palavra (IF, § 16). Dessa forma, o modelo de ensino ostensivo das cenas de aquisição da linguagem não dá conta das diferenças de "espécies de palavras" (IF, § 17), portanto, se o ensino é ostensivo, o significado não o é. A significação é resultado do recurso consciente às regras aprendidas no jogo de linguagem; contudo, essas regras emergem no momento da aplicação dos jogos, o que, segundo Prado Jr. (2004: 85), manifesta o caráter reflexionante da linguagem ou do pensamento. Em suas palavras:

Não que a consciência produza misteriosamente (como numa superabundância genial ou romântica, ou por alguma forma de intencionalidade operante) significação ou verdade. Talvez porque seja impossível pensar ou falar significativamente sem se aperceber de que isso é feito (como se a sombra da reflexão acompanhasse necessariamente a prática do pensamento e da linguagem) (PRADO JR., 2004: 97). 
As cenas de aquisição da linguagem do jogo de ostensão, portanto, mostram alguns problemas que surgem em função de se reduzir o ensino de uma língua ao ensino ostensivo de nomes de objetos, seres, cores etc. O uso da analogia com o jogo de xadrez proporciona maior esclarecimento sobre esses equívocos, pois mostrar uma peça do jogo, seja o rei ou a rainha, por exemplo, não garante a imediata compreensão das regras do jogo, tampouco os movimentos que essas peças realizam. Além disso, por mais aprofundado que seja o conhecimento acerca das regras do xadrez, não é possível prever todos os lances que podem ocorrer em uma partida, pois a prática do jogo é o que traz a habilidade tanto com as regras quanto com os movimentos. Trazendo essa analogia para o campo da linguagem, a compreensão de uma palavra é alcançada a partir da instrução, do treino e da prática, isto é, a linguagem, fundamentalmente um sistema normativo, e são suas normas, justamente, que levam à utilização das palavras. A ideia de uma "imagem mental" compartilhada, em realidade um quebra-cabeça que jamais foi possível desembaralhar, torna-se dispensável e mesmo indesejável se podemos perceber a linguagem como uma dinâmica que envolve muito mais do que os nomes, como nos mostra Wittgenstein.

A explicação citada no exemplo da cor vermelha não abarca, tampouco revela a essência da cor vermelha, do que seria vermelho, nem garante, com isso, uma autoridade sobre o uso de proposições da língua. Sobre essa passagem, Perloff (2008: 85) ressalta que, a partir de cenas do cotidiano, o filósofo vai tentar nos livrar de um tipo particular de quebra-cabeça:

Quebra-cabeças filosóficos são irrelevantes para a nossa vida cotidiana. Eles são quebra-cabeças de linguagem. Instintivamente nós usamos a língua de forma correta; mas, para o intelecto, esse uso é um quebra-cabeça. É a formação desse uso "instintivo" da língua, uma série de hábitos que podem ser estudados antropologicamente - como argumentava seu amigo de Cambridge, o economista marxista italiano Piero Sraffa - que se tornou o novo foco de Wittgenstein. (PERLOFF, 2008:85).

Ao investigar a passagem da infância à fase adulta, isto é, do período que compreende a impossibilidade de produzir linguagem até o atingir dessa capacidade, Wittgenstein se detém detalhadamente nessa noção de que o aprendizado das palavras, quando se aponta um objeto, realmente constitui razão para pensar que o significado seja o objeto apontado. Mas as profundas investigações feitas pelo filósofo constatam que a relação entre um nome e um 
objeto não é monolítica (IF § 8; GLOCK, 1997: 226). Por meio do "treinamento" feito no uso, o significado das palavras é aprendido, por isso se compara ao xadrez, que é aprendido não pela associação de peças a objetos, mas por meio da observação da movimentação de cada peça. Discute-se, também, a forma como o ensino está relacionado ao significado dado a uma palavra e, consequentemente, discute-se ainda que, como se disse, o ensino de uma língua é normativo, como destacam Baker \& Hacker:

Wittgenstein emphasized the internal connection of word-meaning and explanation, which is antecedent to any empirical investigations. Meaning is what is explained in giving an explanation of meaning. [...] They are not descriptions of habits of word usage, but state rules or standards for the correct use of a word. They are not theoretical but ground-level specifications of rules for the uses of words, just as the statement of the rules of chess are not theoretical, but describe how the game is to be played (BAKER \& HACKER, 2004: 29).

Para além das contradições em que incorremos ao desejarmos descrever a aquisição de uma língua apenas por meio do ensino ostensivo, há ainda a questão que se apresenta como um dos temas centrais da primeira parte das Investigações: a negação da proposição inicial no Tractatus, a teoria pictórica do significado, segundo a qual os nomes são a base da linguagem significativa, pois designam o objeto. Os nomes, centrais na imagem representacionista, perdem agora a primazia. Sobre isso, Perloff comenta que, para Wittgenstein, assim como para alguns artistas, "um pronome, parece, é um modo de escapar da prisão do rótulo, de um nome fixo" (PERLOFF, 2008: 120). Lembrando o $\$ 410$ das Investigações, ${ }^{10}$ Perloff comenta que para o estrangeiro (e acrescentaríamos, para as crianças) "essas são as palavras que causam a maior confusão" (PERLOFF, 2008: 118).

Voltando à exegese canônica, Baker \& Hacker (2004: 2-3) têm, sobre a cena de abertura das Investigações, um extenso comentário que pode nos ajudar a aprofundar a crítica de Wittgenstein sobre a concepção essencialista da linguagem. Citamos:

a) Toda palavra tem um significado;

b) Este significado é correlacionado à palavra;

c) O significado de uma palavra é o objeto que ela representa.

\footnotetext{
10 "Eu" não denomina nenhuma pessoa, "aqui”, nenhum lugar, "este" não é nenhum nome. Mas estas palavras estão em conexão com nomes. Os nomes são explicados por meio delas. É também verdade que a física se caracteriza por não empregar essas palavras (IF, §410)
} 
d) A forma da explicação 'Isto é... ', ou seja, uma explicação ostensiva, constitui os "fundamentos da linguagem";

e) A criança pode pensar, i. e., falar consigo mesma (na linguagem do pensamento, por assim dizer) antes de aprender a língua materna com seus pais, tal como um aprendiz de uma língua estrangeira.

f) A função essencial de uma sentença é a de descrever como as coisas são.

A última assertiva, sobretudo, mostra a ausência de perspectivas anunciada pela visão da linguagem como representação. De acordo com as reflexões de Wittgenstein, as implicações de tal concepção sobre a linguagem não são poucas e moldaram séculos de reflexão sobre a "verdade" traduzida em linguagem, como vemos na interpretação de Baker \& Hacker:

The Augustinian conception of the essence of human language has moulded centuries of reflection. It is not itself a 'theory of language', let alone a 'theory of meaning'. It is, rather, a framework of thought, a conception commonly taken for granted prior to systematic reflection. It is, as it were, the gravitational field within which much European speculation on the nature of language has operated. Against the background suppositions that the essential function of words is to stand for things, that the things words stand for are what they mean, and that words are correlated with their meanings by ostension, which connects language to reality, many questions arise and are given a variety of different, often incompatible, answers. [...] In altogether characteristics manner, it is primarily this that Wittgenstein attacks $[\ldots]$ the common presuppositions (BAKER \& HACKER, 2004: 3).

Sobre o assunto, Glock (1998) ressalta que após as discussões de Wittgenstein com o Círculo de Viena, o filósofo evidenciou sua oposição ao pensamento dos positivistas lógicos, para os quais "as definições ostensivas eram um meio de injetar conteúdo empírico em um cálculo formal não interpretado" (GLOCK, 1998: 123). Wittgenstein, ao contrário do que pregava o Círculo de Viena, rechaça a ideia de que uma definição ostensiva forneça uma "conexão entre a linguagem e a realidade" (GLOCK, 1998: 123). As definições ostensivas possuem, isso sim, função normativa como outros tipos de explicação gramatical e, além disso, funcionam como regras de substituição; autorizam, por assim dizer, a substituição de determinada expressão demonstrativa pelo termo definido.

Uma definição ostensiva do vermelho, por exemplo, permite-nos passar de "Minha bicicleta é desta cor" para "Minha bicicleta é vermelha". [...] A linguagem permanece autônoma porque as amostras utilizadas nas definições ostensivas são parte da gramática. [...] Essa ideia não configura uma extensão estipulativa do 
conceito de linguagem. Lembra-nos, em vez disso, do fato de que as amostras funcionam como padrões para o uso correto das palavras, tendo, assim, um papel normativo, análogo ao das proposições gramaticais (GLOCK, 1998: 123).

Wittgenstein prossegue seu encadeamento de ideias, onde aponta a cena de uma criança que aprende uma língua não por explicação, mas por "treinamento" (IF §5), isto é, em seus dizeres, a criança é treinada no uso das palavras, devendo estabelecer uma ligação associativa entre a palavra e o objeto, pois foi treinada a utilizar palavras específicas para executar atividades determinadas, assim como se treina também a forma como deve reagir às palavras dos outros (IF §6). Apontar para um objeto é algo importante para treinar a criança e ensinar a ela uma língua; entretanto, o ensino ostensivo das palavras possui esse papel no processo de socialização linguística pelo fato de situar-se em um cenário de relações interpessoais, em que o ato de indicar supõe um mecanismo próprio. $\mathrm{O}$ ensino ostensivo das palavras é, portanto, um jogo de linguagem que necessita de alguma competência linguística anterior a ele para dar significado à definição ostensiva (IF §7). Para o indivíduo nomear ou demonstrar algum objeto, é necessário o domínio de outras atividades, que ocorrem no jogo linguístico, para preparar e dominar o uso daquela palavra (IF §26, 27, 31).

Cavell (1996[2012]: 259), ao discutir o jogo de nomear corrobora com o que aqui já se disse, questionando a pretensão filosófica de responder à questão da apreensão do significado dizendo que "há universais aos quais as palavras correspondem", o que acarreta, por sua vez, na questão de conceder ou negar um estatuto ontológico a esses universais, isto é, explicar ou negar o conhecimento que temos deles. Wittgenstein, quanto a isso, nos faz ver que nenhuma resposta pode fornecer uma explicação satisfatória a essas questões. Cavell reflete com Wittgenstein que o aprendizado é muito maior do que o que nós supomos e não cabe nas explicações essencialistas, nem nas ceticistas, em todos os casos, insatisfatórias. Percebemos isso quando, por exemplo, exemplifica Cavell, damos como certo que nossa criança aprendeu o que significa gatinho, pois ela foi capaz de apontar um e pronunciar a palavra. Para nossa surpresa (e talvez decepção, aponta Cavell), alguns dias após havermos constatado esse aprendizado, nossa criança diz gatinho para uma manta feita com pele de animal... Ela não sabia exatamente o que queria dizer gatinho... Nossa segunda reação, talvez mais positiva, será a de perceber que à palavra gatinho corresponde uma série de outras 
significações: suave, agradável ao toque etc. Constata-se, assim, que a sintaxe de tal desempenho possa corresponder a: "Isto é como um gatinho.", ou: "Olha esse gato esquisito!”, ou: “Que legal! Como é suave!” ou ainda: "Veja, eu me lembro de como você fica feliz quando eu digo 'gatinho'!". Aprender uma língua mostrase, assim, muito mais do que aprender a nomear. Quando uma criança em fase de aquisição da linguagem faz ver que os parafusos que julgávamos apertados não estão, na verdade, tão ajustados como presumíamos, temos uma oportunidade de refletir sobre as explicações sobre uma pretendida estabilidade dos significados.

Cavell lembra que por meio da cena inaugural das Investigações Wittgenstein constata que bem pouco do que se faz com uma linguagem é nomear, ao contrário do que apregoa a visão representacionista da linguagem. Por fim, Cavell resume:

ao "aprender uma linguagem" não aprendemos apenas o que são os nomes das coisas, mas o que é um nome; não apenas o que é a forma de expressão que convém à expressão de um desejo, mas o que é exprimir um desejo; não apenas o que é a palavra para "pai", mas o que é um pai; não apenas a palavra "amor", mas o que é o amor. Aprendendo a linguagem, não aprendemos apenas a pronúncia dos sons e sua ordem gramatical, mas também as "formas de vida" desses sons, as palavras que são capazes de fazer o que elas fazem - por exemplo, nomear, chamar, apontar, exprimir um desejo ou uma afeição, indicar uma preferência ou uma aversão, etc. Segundo Wittgenstein, as relações entre essas formas são igualmente "gramaticais". (CAVELL, 1996[2012]: 271).

Assim, o aprendizado da linguagem apresentado por Agostinho é discutido por Wittgenstein não mais como um modelo capaz de dar conta de toda a complexidade aí envolvida, mas como um jogo primitivo ao qual Wittgenstein adere, mas somente até certo ponto. Onde as explicações falham, Wittgenstein operacionaliza e chama a atenção para as ações na cena de aprendizagem e, diferente de Agostinho, que assume a perspectiva da pessoa que aprende, Wittgenstein se coloca fora da cena, como observador:

Wittgenstein adota um ponto de vista diferente do de Agostinho; como observador, ele permanece na esfera dos eventos externos. Ele também observa e tira conclusões; contudo, ele não constrói um evento interno, mas o resume sob conceitos que pertencem a uma linguagem da observação. Contra a perspectiva e a linguagem mentalistas de Agostinho, ele defende um modo de observação naturalista. Com certeza, seu procedimento foi especialmente inspirado por suas discussões com Sraffa (GEBAUER, 2013: 73). 
Assim como em Agostinho, as reflexões sobre o significado em Wittgenstein se iniciam na criança ainda bem pequena, que ainda não sabe muita coisa a respeito de significados e regras, mas que já adquiriu habilidades por meio de um "aprender a fazer igual": ela não imita apenas os sons das palavras, mas os gestos, como o de apontar, assim como também já percebe, antes de poder imitar a fala e os gestos, as expressões faciais dos adultos com quem convive, o que certamente contribuirá para o sucesso do aprendizado das regras do jogo da ostensão. Podemos então, auxiliados por Wittgenstein, perceber que a criança apreende essas regras na ação: o que se vê como puramente cognitivo, é antes uma concordância das ações de adultos e de crianças.

A disposição de Wittgenstein para o "olhar de fora" e sua abertura para a inclusão das ações aprendidas juntamente com o aparecimento da linguagem, desmonta, por assim dizer, a tese essencialista, já que não mais há a necessidade de um tertius para a compreensão do sensível. Prado Jr. alerta que essa articulação entre o empírico e o transcendental, que abre mão do argumento do Terceiro Homem, já aparece no Tractatus:

\begin{abstract}
Retornemos à questão da possível articulação entre o empírico e o transcendental fora do esquema "ternário" da filosofia kantiana. Aqui, novamente, reencontramos Wittgenstein, que leva ao máximo a aproximação entre o empírico e o transcendental, que também inclui o conceito de "vida" no léxico do transcendental, desde o Tractatus até seus últimos escritos, quaisquer que tenham sido as transformações de seu pensamento ao longo do tempo. Também no Tractatus evita-se a estrutura ternária da Crítica da razão pura e a necessidade de um tertius para a aplicação do entendimento ao sensível é cancelada. Nas proposições de 1 a 1.21, com a circunscrição dos fatos no interior do espaço lógico, a contingência pura acomoda-se imediatamente (e sem atrito) na épura do necessário. Mais ainda, nos estados de coisas, a "partição" entre as coisas não exige nenhum termo mediador, já que se ligam umas às outras "como os elos de uma corrente" (PRADO Jr., 2005: 167).
\end{abstract}

Podemos dizer, então, que Wittgenstein não apenas amplia a questão da significação, mas introduz uma nova e necessária reflexão sobre o que vem a ser hoje "transcendental" ao relacionar vida e conhecimento, vida e linguagem, de modo a transpor a dificuldade imposta pelo recurso ao Tertius ou, numa alusão à contiguidade semântica em que se agarra o recurso, como lembra Agamben, ao pneuma, ao spiritus, ao esprit, ao Geist (AGAMBEN, 2005: 29). Ao lançar-se (e lançar-nos) nessa reflexão, Wittgenstein cumpre, por assim dizer, o que Agamben (2005: 11) chama de "tarefa urgente do pensamento contemporâneo": a 
redefinição do conceito de transcendental em função de suas relações com a linguagem. Os jogos de linguagem, desde os mais primitivos, como o jogo da ostensão, até os mais complexos, encontram-se ancorados numa prática a ser aprendida em acordo com uma forma de vida e não em algo que esteja fora da linguagem a que podemos misteriosamente acessar. Por isso, todos os jogos de linguagem, Wittgenstein adverte reiteradas vezes, estão em igual posição hierárquica, o que equivale dizer que, ao contrário do que tende a julgar a tradição filosófica ocidental, nenhum é mais (nem menos) aparentado com a verdade.

\section{2}

\section{A linguagem como forma de vida}

Desde o Tractatus, como vimos em Prado Jr., Wittgenstein lança fora o recurso ao tertius, sendo a vida, como veremos mais à frente, na comparação com a filosofia de Deleuze, um "campo transcendental" ou um "plano de imanência", embora no Tractatus ainda despojada da dimensão do tempo ou do fluxo. Com a remodelação da teoria da significação operada por Wittgenstein a partir dos anos 30, a temporalidade torna-se peça essencial da reflexão: "a significação só emerge no fluxo da vida e a Razão torna-se 'contingente como a vida"” (Prado Jr., 2004: 167-168). Por isso, é preciso prestar mais atenção à linguagem como parte indissociável da vida:

É considerando indissolúvel o vínculo entre a linguagem e as atividades humanas que entretecem essa 'nossa complicada forma de vida' (IF p. 224) que Wittgenstein sustenta que o significado das expressões linguísticas tampouco pode ser compreendido como uma propriedade dessas expressões que independe de seus usos em certos contextos (MARTINS, 2009: 28).

Quando a temporalidade, a vida em seu fluxo, passa a ser parte essencial das reflexões de Wittgenstein sobre a significação, vemos surgir as expressões que são chaves de seu pensamento maduro: "forma de vida", "jogos de linguagem", "quadro de referência", "certeza", "crença" etc. que, estando entrelaçadas, devem ser pensadas para um melhor entendimento da própria questão da temporalidade. A significação emerge no momento da enunciação e por isso mesmo está em harmonia com um contexto e com o que Glock define como "uma espécie de naturalismo" e explica: 
Nossas atividades linguísticas e não linguísticas são condicionadas por certos "fatos da natureza". Nossos conceitos apoiam-se sobre uma determinada "armação de fatos", na medida em que diferentes fatos da natureza tornariam inteligíveis diferentes "formações conceituais" (PI II 230; RPP I §48; Z §§350, 387-8). (GLOCK, 1998: 307).

A noção wittgensteiniana de quadro de referência, é, portanto, fundamental tanto para a formulação dos jogos de linguagem e das práticas linguísticas quanto para outras importantes reflexões presentes em sua obra, como gramática e forma de vida. Glock inicia a abordagem de quadro de referência em Wittgenstein pela comparação das concepções presentes nas primeiras e nas últimas obras do filósofo. Retomar alguns dos pontos que o estudioso da obra de Wittgenstein destaca será útil a este trabalho, principalmente porque nos permitirá elucidar as relações indissociáveis entre alteridade e "quadro de referência" já que este último abrange os convencionalismos, as normatividades, bem como a atribuição ou não de sentido às expressões.

Glock lembra que, em sua primeira obra, o filósofo trabalha no interior de um escopo reduzido de quadro de referência, sendo irrelevante a ligação da proposição verbal com fatores extralinguísticos para saber se ela possuía ou não sentido. Os primeiros indícios da mudança no tamanho do escopo pelo qual Wittgenstein considera o sentido, para Glock, dão mostras de que dois eixos são fundamentais nessa transição, o contextualismo e o naturalismo a que já nos referimos anteriormente, mas aos quais retornamos para melhor entendimento. $\mathrm{O}$ primeiro se refere a uma radicalização da ideia de que uma palavra somente possui sentido no interior de um jogo de linguagem, que, por sua vez, é parte de uma forma de vida comungada por um determinado grupo de pessoas. Já o segundo, de cunho mais complexo e que possui raízes por toda a filosofia wittgensteiniana, postula que nossos conceitos são estruturados pelas leis da natureza, inferindo-se disso que, se tais leis fossem distintas, nossos conceitos também seriam diferentes dos atuais (GLOCK, 1998: 307). Ainda sobre esse eixo, Wittgenstein mesmo esclarece, no $\$ 415$ das Investigações que "[o] que fornecemos são propriamente anotações sobre a história natural do homem; não são curiosidades, mas sim constatações das quais ninguém duvidou, e que apenas deixam de ser notadas, porque estão continuamente perante nossos olhos" (grifo nosso). A respeito dessa atenção que remete à área da antropologia, vemos em Gebauer que os próprios termos usados por Wittgenstein são já uma prova de que 
sua filosofia madura está amparada, por assim dizer, por um olhar antropológico e, acrescentaríamos, perspectivo:

Podemos reconhecer o viés antropológico de seu pensamento nas expressões por ele introduzidas - jogos de linguagem, semelhanças de família, figuras, ver como. Elas não formam uma terminologia especializada, mas têm suas raízes na linguagem cotidiana e preservam tanto quanto possível seus modos de uso: Wittgenstein descreve o funcionamento dos jogos de linguagem de maneira muito semelhante a um evento cotidiano em jogos de bola. A semelhança entre usos análogos de palavras, tal como a semelhança entre membros de uma família, é reconhecida em sua aparência similar - as palavras têm um "rosto conhecido" (UP II, p. 560). As figuras podem nos aprisionar (PU, §115), tal como nos obstinamos com certas concepções figurativas. Aquelas expressões que indicam um uso mais técnico como "regras" e "seguir regras", não são entendidas por Wittgenstein no sentido de regras explicitamente formuladas, de maneira análoga às regras lógicas, mas no amplo sentido de um evento regulado. Por fim, o conceito de critério nas reflexões dos últimos anos de vida é desenvolvido como suposição de um "padrão no tapete da vida" (cf. Z, § 568). (GEBAUER: 2013: 16)

Assim, a ideia de quadro de referência se mostra em estreito vínculo com o

fluxo da vida, com as formas de vida, com os jogos de linguagem e, por fim, com a questão fundamental para o modo de filosofar de Wittgenstein: a impossibilidade de dar estabilidade absoluta aos significados. No acordo entre as pessoas, no entanto, é possível haver certa estabilidade: aí se mostra uma forma de vida. O fato de que é possível assumir um sentido - que, em realidade, possui respaldo no consenso de uma coletividade, isto é, no fato de possuir certa interpretação estável - pode ser mais bem observada em três elementos resumidos por Glock (1998:307). O primeiro deles está relacionado à gramática, imprescindível na constituição de um jogo de linguagem, e que, como na medição de algo, por exemplo, estabelece parâmetros inteligíveis ao grupo que deles se utiliza. O segundo elemento é a aplicação das regras em proposições empíricas (no jogo de medir, por exemplo). Talvez esse seja o ponto de inflexão entre seu trabalho no Tractatus e sua produção da maturidade, já que estabelece uma ampliação no conceito de quadro de referência, ao propor novo critério para o sentido. Quanto ao último elemento, nota-se que ele funciona como uma reflexão sobre as próprias bases epistemológicas do que pode ser considerado significativo (possuidor de sentido), uma vez que consiste da investigação sobre as leis e estruturas que nos permitem operar um jogo de linguagem, dele depreendendo algo. Referindo-se aos $\S \S 240$ a 242 das Investigações, Glock procura apagar eventuais confusões que possam existir sobre o que é considerado acordo ou 
consenso por Wittgenstein. Primeiramente, afirma que o consenso no uso da linguagem deve ser tomado enquanto acordo sobre forma de vida, ou seja, sobre o funcionamento da linguagem (como na descrição de medidas métricas), e não nas definições e julgamentos que são obtidos em sua utilização. Conforme pondera o próprio filósofo, prova disso é que, ainda que possuam sentidos relativamente estáveis, a utilização de expressões pela linguagem pode gerar diferentes reações e que, caso houvesse consenso total, a existência da lógica seria dispensável. Não é, portanto, o consenso o fator que determina o sentido, mas sim a correta aplicação das regras (GLOCK, 1998: 307-8). Assim, a boa aplicação das regras é de importância fundamental para que se possa estabelecer um jogo de linguagem, mas, como vimos, as regras emergem no jogo, no fluxo da vida.

\subsection{1}

\section{Sobre crenças e certezas}

Die Rose ist ohne Warum.

Sie blühet, weil sie blühet. Sie achtet nicht ihrer selbst, Fragt nicht, ob man sie siehet. ${ }^{11}$ Angelus Silesius

Como este estudo inclui o contato com uma forma de vida diversa à nossa, a ameríndia, tal como a ela fomos apresentados pelo estudos etnográficos de Eduardo Viveiros de Castro, acreditamos ser de grande interesse que nos detenhamos em aspectos cruciais para o modo de filosofar wittgensteiniano que se detém em palavras ou expressões como "saber", "ter certeza", “conhecer". Salientamos, no entanto, que o confronto buscará primordialmente abrir mão de explicações mentalistas no que concerne ao significado para, aderindo à visão wittgensteiniana, entender que

o que determina se compreendemos uma expressão é nossa manifestação dessa compreensão ser aceita como lance legítimo no jogo de linguagem, ser tomada como adequada no contexto particular em que ela é produzida: na situação particular, segundo os costumes da cultura particular, no momento particular da história, etc." (MARTINS, 2009: 33).

\footnotetext{
${ }^{11}$ A rosa é sem porquê / ela floresce porque floresce / sem prestar atenção em si / sem perguntar se alguém a vê (Angelus Silesius)
} 
Para Perloff, o anti-essencialismo de Wittgenstein aparece desde a sua maneira de escrever filosofia de um lugar muito próximo à poesia, apontando que o filósofo vai da teoria ao "jogo de linguagem" (2008:87). Observar o jogo leva à percepção de que uma definição essencialista é uma ilusão: todo sentido está no jogo construído, por isso, à filosofia não cabe teorizar, mas descrever: "a descrição assume um papel novo, pois descrever a estrutura e a função de um jogo de linguagem particular é esclarecer, de uma vez, as ideias erradas" (PERLOFF, 2008: 90). Mais adiante, Perloff tocará em um ponto chave para o entendimento da filosofia de Wittgenstein, ao trazer os comentários do filósofo sobre The Golden Bough [O Ramo de Ouro], de Sir James Frazer:

Aqui Wittgenstein toca num dos pontos doutrinários da modernidade: a metanarrativa do progresso, de uma evolução gradual da barbárie "primitiva" para a ilustração moderna. The Golden Bough tenta "explicar" o ritual mágico e religioso primitivo - e, implicitamente, o ritual cristão - como uma forma de ignorância que deve ser eliminada por "nós", que sabemos muito mais do que os povos "primitivos". A reação de Wittgenstein não é a de justificar essa ou aquela prática ou discutir se o sistema de crença de Agostinho era verdadeiro ou falso, mas submeter os argumentos de Frazer a uma série de jogos de linguagem simples. Ele se coloca no lugar do observador externo, um observador fora da moldura cultural específica que teria de assumir que, se Agostinho não estava "errado", então o religioso budista está errado e assim por diante, resultando no fato de que todas as práticas religiosas aparecem apenas como meras Dummheiten. ${ }^{12}$ (PERLOFF, 2008: 90-91)

Perloff segue argumentando que "o objetivo de Wittgenstein não é refutar os fatos trazidos por Frazer, dando exemplos de outros, mais atualizados, mas prestar mais atenção ao que uma determinada descrição pode e não pode nos dizer de fato" (2008:91). Ou seja, nossa pressa em julgar é altamente desaconselhável, pois nossos jogos de linguagem carecem de uma fundamentação última, tanto quanto qualquer outro jogo. Descartando completamente os dogmas e a possibilidade de uma linguagem ligada à alguma essência que se esconde ao humano, cai por terra a exigência de um fundamento último. Para Perloff, o afastamento de Wittgenstein da filosofia tradicional, por absoluta ausência de teoria, é tal que o modo de fazer filosofia de Wittgenstein “já não é mais absolutamente filosofia” (2008:93), dada a ausência de linearidade, de progressão lógica das suas investigações. O filósofo propõe, segundo Perloff,

\footnotetext{
${ }^{12}$ Dummheiten (al.): tolice.
} 
Não uma teoria abrangente, portanto, mas um método para "ir em frente"-isso é o que torna tão interativos os textos das Investigations, junto com Culture and Value, The Blue and the Brow Books e os das várias palestras e cadernos postumamente publicados. Porque é aqui, na linguagem sempre a ser reformulada, recomposta ou recarregada com uma nova metáfora ou exemplo, que está a desconstrução do nosso próprio emprego da língua no que ele tem de mais insidioso e desconcertante - por mais usual que seja (PERLOFF, 2008: 94).

Perloff chama a nossa atenção para o próprio uso, por parte de Wittgenstein, desse conceito de gramática que tanto nos lembra Nietzsche, como veremos mais adiante. O cerne dessa gramática já não é mais a sua estrutura lógica, capaz de gerar tanta confusão, mas a instabilidade do significado e por isso, cada frase tem potência para revelar "um novo modo de olhar para as coisas" (PERLOFF, 2008:108). Não é de estranhar, pois, que os substantivos e adjetivos deixem de ser o centro de atenções e que as chamadas "palavras gramaticais", preposições, conjunções, artigos e pronomes, especialmente estes, sejam tão interessantes para Wittgenstein, pois são essas palavras que garantem, muito mais que os substantivos, a possibilidade, cara ao perspectivismo, do "ver como". Relacionar sua filosofia a um perspectivismo filosófico como o que encontramos em Nietzsche e Deleuze se revela assim em concomitância a advertências que são também um "dever" do filósofo: desfazer as confusões a que nossas crenças, uma vez incrustadas na linguagem usual, nos levam, isto é, retirar o poder das "frases feitas"; por outro lado, trazer palavras como "conhecimento", "aprendizagem", "verdade" de seu uso "ideal", o da filosofia, para o uso cotidiano, livrando os filósofos da tarefa de "melhorar" a linguagem usual, pois, como insiste Wittgenstein no Livro azul "a linguagem comum é perfeita" (BB, 1992: 62).

Com isso não só alargamos nosso entendimento sobre a linguagem, como também nos colocamos mais expostos ao imprevisível, alerta que o próprio Wittgenstein frisou no $\$ 559$ de Da Certeza: você deve ter em atenção que o jogo de linguagem é, por assim dizer, imprevisível. Quero dizer: não se baseia em fundamentos. Não é razoável (ou irrazoável) (UG, 2009: 157). O que exige de nós, para começar, uma disposição para rever os alicerces sobre os quais calcamos nossas verdades. Lembrando que os últimos escritos de Wittgenstein constituemse uma crítica à filosofia realista de Moore, Prado Jr. sublinha que "a verdade de certas proposições aparentemente empíricas pertence ao nosso quadro de referência, isto é, à própria base do nosso Weltbild"' (PRADO Jr. 2004: 31), daí a importância de bem compreender a noção de jogos de linguagem, retirando das 
proposições o peso ontológico que a gramática lhes confere, atribuindo significado no acordo de uma prática situada no fluxo da vida. Nesse sentido, são esclarecedores seus comentários ao "rio de Heráclito", quando infere que abandonar o platonismo não implica necessariamente agarrar-se ao empirismo:

Wittgenstein parece insistir na diferença entre o movimento das águas e a mudança do perfil das margens do rio, porque a mudança das margens ou do leito é a mudança do próprio rio. Um jogo de linguagem permanece o mesmo, mesmo se proposições, nele consideradas verdadeiras, passam a ser consideradas falsas e vice-versa. Mas se o bloco ou o aglomerado das proposições polares - a mitologia de base - muda, não mais se pode dizer que jogamos o mesmo jogo e que nos banhamos no mesmo rio. Não é o mundo que se revela volúvel, mobile quale la donna, apenas nós mudamos as regras de nosso jogo e, com elas, nossa forma de vida, isto é, nós mudamos (PRADO Jr., 2004: 35).

Mais a frente Prado Jr. pontua, confirmando ainda uma vez (e com outras palavras) o que aqui já se disse: para haver acordo entre os participantes de um jogo, há de haver também entre eles um único Weltbild:

Se não partilharmos o mesmo Weltbild, não jogamos o mesmo jogo de linguagem, não obedecemos às mesmas regras. [...] Numa palavra, a universalidade dos "princípios universais da pesquisa humana" topa com um limite inultrapassável na escolha, sempre arbitrária, dos princípios sem os quais não se cristaliza um Weltbild ou se institui uma Weltanschauung. (Prado Jr., 2004: 49)

Um Weltbild nos é transmitido por ensinamentos que ocorrem em concomitância à aquisição da linguagem: é o acordo entre os homens. Não há, no entanto, garantias de fundamentos que ancorem o Weltbild a nós transmitido, é o que a tarefa de filosofar sem o aparato de uma lógica amparada no mentalismo nos dirá. Haverá, em todo e qualquer Weltbild, o lugar "onde a pá entorta” e onde teremos de nos render, pois chegamos aos limites da fundamentação. Tudo isso mostra a importância de distinguirmos entre persuasão e fundamentação. O minucioso trabalho com a oposição crença $v s$ certeza vai consolidar a crítica de Wittgenstein, por meio da analogia com os jogos, tanto da visão realista quanto da idealista. A concepção de uma Idade da Razão, tão cara a Descartes, é rechaçada diante da precariedade dos Grundprinzipien da pesquisa humana.

Numa palavra: se tenho que persuadir alguém, é porque não tenho (nem posso ter) fundamento ou razões para convencê-lo. Persuadir alguém é leva-lo a admitir, justamente, o que não tem base, uma "mitologia", algo que está muito além, ou aquém, da alternativa entre o verdadeiro e o falso, o racional e o irracional ou, melhor dizendo, entre a sensatez e a loucura, entre o Cosmos e o Caos. Muito mais que a Razão, na persuasão, está envolvida a autoridade, a assimetria entre aquele 
que ensina, mesmo recorrendo à violência, e o aprendiz - a mesma assimetria que existe entre o missionário e o nativo. (PRADO Jr., 2004: 48)

Assim, se duas formas de vida são confrontadas, haverá o lugar de questionamento das certezas que dão base ao Weltbild que funda, por assim dizer, cada uma dessas formas de vida. Filosofar com Wittgenstein é sobretudo tentar não tansformar os Weltbilder em Weltanschauung, o que ocorre quando uma delas entende que os fundamentos de suas proposições fulcrais são um espelho da verdade, podendo, ao fazer uso desse entendimento, se precipitar em julgamentos, sem perceber, no entanto que "conhecer" e "saber" ou "ter certeza" traduzem, não raras vezes, relações com nossas crenças. São nossas práticas que dão os fundamentos onde se encoram nossas certezas. Com isso podemos concluir, como Glock, que "a bem da verdade, os fundamentos últimos de nosso conhecimento não são crenças, mas formas de comportamento", pois, por exemplo, eu agarro, com minhas duas mãos (para fazer referência a um dos truísmos de Moore contestados por Wittgenstein), a bola que é atirada em minha direção.

Nas reflexões de Glock sobre o verbete "certeza" lemos que "nossos jogos de linguagem só podem ser praticados sobre um pano de fundo de certezas relativamente permanentes" (GLOCK, 2008: 76), isto é, Wittgenstein argumenta que a relativa estabilidade do mundo é o ponto de partida de muitas de nossas certezas, mas com elas não atingimos ainda a possibilidade de usar o verbo saber, tal como Moore o faz, de modo a confundir "ter certeza" com "conhecer sem possibilidade de dúvidas", a menos que, negando a autonomia da linguagem, admitíssemos que a linguagem pudesse refletir uma essência da realidade. Não sendo esse o caso, admite-se que a certeza de uma crença existe em função do quadro geral de crenças, ou ainda, existe certeza quando se pode lançar mão dessa crença para justificar outras crenças, sem que ela mesma necessite de justificação (GLOCK, 1998: 78). Em função disso, Glock aponta a obra Da Certeza como fornecedora de uma epistemologia socializada, colocando o conhecimento acumulado de uma cultura como uma conquista coletiva, além de caracterizar o aprendizado como baseado na aceitação da autoridade de uma comunidade (UG 
$\S 161)^{13}$, o que não implica, no entanto, negar o pensamento crítico. Para melhor entendimento, citamos Gebauer:

Com a forma de vida em que vivem, agem, julgam e falam, as pessoas adotam uma rede de certezas às quais estão atadas de maneira mais profunda do que seria possível por meio do saber: pela crença na "mitologia" dada pela forma de vida, como diz Wittgenstein (ÜG, §95). Sua discussão dos conceitos de "certeza" e "crença" revela como o pensamento de Wittgenstein não se dirige tanto ao conhecimento do mundo quanto à relação do sujeito consigo mesmo (GEBAUER, 2013:20).

Muito embora as ponderações encontradas em Da certeza tenham profundas implicações tanto para a filosofia essencialista quanto para a realista, por terem, todas as ponderações, raízes na (im)possibilidade de um significado estável, são por isso também muito úteis quando discutimos especificamente as teorias do significado nos estudos da linguagem, como registra Martins:

Compreender a perspectiva oferecida por Wittgenstein supõe contemplar a possibilidade de que a linguagem possa ser estável sem representar algo de exterior a ela mesma, "sem ser razoável ou irrazoável", sem "possuir fundamentos" (On Certainty §559). Atentar para o fato de que, afinal, é possível sabermos usar uma palavra em renovados contextos sem que sejamos capazes de apontar uma entidade que a governa (MARTINS, 2009: 38).

Aderir à prática wittgensteiniana de olhar como eu ajo, como eu faço percebendo a partir desse olhar a enorme relação entre essas práticas e a atribuição de significados que damos às palavras, leva-nos necessariamente a relacionar vida e linguagem: "Na vida da linguagem originam-se significados, semelhanças de família e jogos de linguagem novos, enquanto outros, por sua vez, envelhecem e são esquecidos" (GEBAUER, 2013: 14). Se defendemos uma continuidade no pensamento de Wittgenstein desde o Tractatus, não nos escapa, contudo, que sua filosofia madura volta-se totalmente para a práxis da ação humana, regulada de maneira a produzir o conceito normativo das regras. Talvez por isso sejam tão frequentes, nas cenas de alteridade que constituem o corpus deste estudo, as cenas de ensino, pois é por meio delas que Wittgenstein vai discutir as relações entre o normal e o natural, que tanto instigam o pensamento de Cavell que, de modo cabal, demonstra que o normal se infiltra no natural de tal forma que já não prestamos atenção à distinção entre um e outro.

\footnotetext{
${ }^{13}$ Aprendi uma enorme quantidade de coisas e aceitei-as na base de autoridade de homens; depois achei que algumas dessas coisas se confirmavam e outras não, de acordo com a minha própria experiência (UG, §161).
} 


\section{2 .2}

\section{Sobre ensino e certezas}

Cavell (1996) debate a questão da normatividade não apenas na linguagem, mas também no ensino, voltando à crítica da visão agostiniana da linguagem, já que aquele conteúdo a ser aprendido é tão imenso que não caberia no ensinamento, assim como a prática não é abarcada pela linguagem - os rudimentos para o uso de uma linguagem foram aprendidos em algum momento, mas isso nem significa que o aprendizado é estanque, nem que ele é o mesmo para todos os indivíduos. O autor utiliza-se, essencialmente, de exemplos pensados por Wittgenstein para refletir, também, sobre as diferentes perspectivas em confronto, de acordo com a situação. É pensada a relação que o ser humano tem com o padrão da linguagem, sua capacidade de identificar uma palavra dentro de determinado contexto e o julgamento acerca da capacidade do indivíduo de reproduzi-la em outros. Dessa forma, é ressaltada a dependência que a linguagem tem da racionalidade, ou seja, em vez de responder à realidade, a linguagem responde ao pré-estabelecido - sendo assim, a linguagem serve de exemplo de como o normativo infiltrou-se na normalidade, de maneira que o próprio indivíduo perca a capacidade dessa diferenciação. Por exemplo, quando Wittgenstein narra a cena de ensino da escala diatônica, em que a cada sete notas, a mesma nota se repete, surge o questionamento do por que se dizer que é ainda a mesma nota:

Quando ouvimos a escala diatônica, sentimo-nos inclinados a dizer que, depois de cada sete notas, volta a surgir a mesma nota e, se nos perguntarem porque é que a consideramos de novo a mesma nota, a resposta poderia ser "Bem, é outra vez um dó". Mas esta não é a explicação que eu pretendo, visto que poderia perguntar "O que é que levou a que ela fosse de novo chamada dó?" E a resposta a esta pergunta seria provavelmente: "Bem, não percebes que se trata da mesma nota, só que uma oitava acima?" Também aqui seria possível imaginar que se tinha ensinado a um homem o nosso uso da palavra "o mesmo", quando aplicada a cores, comprimentos, direções, etc., e que, ao tocarmos agora, para ele, a escala diatônica e ao ser-lhe perguntado se ele diria ter ouvido as mesmas notas, repetidas vezes, em certos intervalos, seria fácil imaginar várias respostas, em particular, por exemplo, a seguinte: que ele ouvia alternadamente a mesma nota cada três ou quatro notas (ele chama à tônica, à dominante e à oitava a mesma nota) (WITTGENSTEIN, BB, [1980] 1992: 83-4).

Dessa forma, são oferecidas, então, duas possibilidades de interpretação: o observador pode dizer que "Eles ouvem coisas diferentes", ou que "B tem um 
modo diferente de ouvir". A diferença que reside entre essas duas colocações está no fato de que, quando se utiliza a primeira frase, embora o ponto de vista do falante demonstre que não é o mesmo de $\mathrm{B}$, foi estabelecida uma naturalização da reação de B. A segunda sentença indica outra interpretação, pois deixa claro ali que B é o sujeito diferente, como uma acusação, e que a reação de B está numa posição senão de inferioridade, de estranhamento, fazendo com que essa reação fique à margem daquela tida como correta. Cavell propõe que, em vez de construir uma explicação para essa disparidade, seria mais proveitoso ou prudente garantir que A e B tenham "espaço no mundo", isto é, garantir que exista a possibilidade de variação dessas reações.

Para alguém de fora, esse tratamento parecerá não apenas severo, mas também injusto, o mais reles motivo pessoal para que alguém seja tratado de modo diferenciado. Não só injusto, como irracional (CAVELL, 1996: 33).

Da mesma forma, Prado Jr. faz suas considerações sobre a possibilidade de ensinar uma crença sem fundamento, dar Grund ao que é Grundlos, afirmando que o que se faz é anular a alteridade, travando com ela uma guerra:

O campo onde se desenrola a persuasão é antes o da guerra que o do entendimento comunicativo mais ou menos transparente. Assim, Wittgenstein pergunta no $\$ 612$ [de Da certeza] há pouco citado: "Disse que 'combateria' [Ich würde 'bekämpfen'] o outro"; e acrescenta que é isso mesmo. Persuadir e converter é quebrar, sem argumento propriamente racional ou razoável, uma segurança, na expectativa de substituí-la por outra. Em todos os parágrafos de 605 a 612, as palavras cruciais e sublinhadas pelo autor (por oposição à palavra razão) são segurança, combate, persuasão. E não poderia ser diferente, já que, se não partilhamos o mesmo Weltbild, não jogamos o mesmo jogo de linguagem, não obedecemos às mesmas regras (PRADO Jr., 2004: 48-9).

Embora os objetivos de Cavell em seus escritos sejam diversos dos de Prado Jr., sendo Cavell muito mais direcionado às nossas práticas relacionadas ao ensino, vemos que a escrita dos dois autores converge para uma apreciação de como consideramos, em geral, a alteridade. Em O normal e o natural (2012, pp.179-185), Cavell discute os aspectos linguísticos e as relações de oposições binárias entre os conceitos de normalidade/loucura e naturalidade/convenção. Enfocando a questão da abordagem filosófica cética para analisar o pensamento wittgensteiniano sobre a linguagem, Cavell discute a característica humana de designar palavras para as coisas do mundo, numa tentativa de abarcar a experiência real através da descrição e nomenclaturas aplicadas. Estabelecendo, 
ainda, um jogo de alteridades, utiliza-se do pensamento wittgensteiniano para debater como, por exemplo, a definição de loucura passa, primeiramente, pela relação de estranhamento entre o Eu e o Outro, entre a incapacidade que o Eu tem de se reconhecer no Outro.

Assim, ao introduzir essa ideia básica das diferentes perspectivas, Cavell adentra na discussão sobre a oposição entre os conceitos de normalidade e anormalidade (ou loucura) e como essas noções advêm desde o processo de aprendizado, quando a criança desenvolve e revela sua própria abstração do mundo. Utilizando-se de alguns exemplos elencados por Wittgenstein no Livro Castanho, o filósofo americano reflete, também, sobre o processo de civilização, de como o sujeito deve seguir a mesma lógica de compreensão possuída por determinado grupo para que assim seja aceito e digno de ser considerado como parte constituinte, igual aos outros. Aqui, há um encontro bastante fértil entre as cenas de alteridade apresentadas por Wittgenstein e as ideias cavellianas.

Imaginar uma situação como essa me causa angústia. Pois eu digo para mim mesmo: eis aí pessoas que têm bastante pressa em separar os loucos dos sãos. [...] E reflito, em seguida: O que seria uma prova cabal da loucura? Não ser capaz de se manter adequadamente na escola durante certo número de anos? [...] é, no entanto, indubitável que tratamos diferentemente as crianças as quais assim sucede, que, por causa disso são marginalizadas (CAVELL, [1979] 2012: 181).

A partir desse raciocínio, Cavell discute as peculiaridades da comunicação, desenvolvendo uma crítica ao ponto de vista de que não é possível estabelecer um processo de comunicação com esses indivíduos considerados "diferenciados", assim como a necessidade que esses sujeitos possuem de, além dos rótulos, estipular uma espécie de justificativa comportamental, retomando sua condenação à tendência de propor explicações lógicas e fechadas para as discrepâncias identificadas nos comportamentos dos indivíduos.

Cavell ilustra seu pensamento elencando exemplos de sujeitos que inovaram técnicas ou atividades quando quebraram os paradigmas de sua época - e, por isso, transformaram o modelo tradicional a partir de perspectivas novas e estranhas, que foram continuadas por todos posteriormente, - como o caso de Bach, que subverteu a técnica de tocar instrumentos como o cravo e o piano ao passar a fazer uso também do dedo polegar, ou, o argumento mais impactante, sobre o antigo costume dos homens de lascarem apenas um lado da lâmina do machado para afiá-la: 
Será que eles eram incapazes de perceber a vantagem de virar a pedra e cortá-la em ambos os lados até chegar ao fio? Durante 10.000 anos? Um dia as pessoas se vêem talhando a pedra dessa nova maneira (CAVELL, 2012: 184).

Evidencia-se assim uma filosofia cujo télos é mostrar, tal como mostra a literatura, e a arte em geral, que a causalidade, por mais reconfortante que possa parecer, não dá conta dos eventos no mundo e que a tentativa de encontrar proposições de valor absoluto, ou explicações totalizantes, esta fadada à frustração. Por isso a rejeição à teoria, qualquer que seja. Interessante observar que há uma coerência entre sua filosofia e essa recusa à teoria, pois "para Wittgenstein, essa recusa de 'linhas retas' é um princípio tanto de composição quanto epistemológico, suas próprias 'conclusões' nunca sendo mais do que tentativas, abertas e sujeitas a revisão" (PERLOFF, 2008: 42).

O usual de Wittgenstein é mais bem compreendido como simplesmente apenas aquilo que é, a linguagem que nós realmente usamos quando nos comunicamos uns com os outros. Nesse sentido, o usual não precisa ser literal, denotativo, enunciativo, neutro, referencial, ou qualquer um dos outros adjetivos com os quais tem sido equiparado no debate usual/literário. Pelo contrário, nossa linguagem real pode muito bem ser conotativa, metafórica, fantástica; a questão é simplesmente se, e em que contexto, as pessoas a usam. (PERLOFF, 2008: 84 - grifo nosso)

Não nos parece mero acaso que o filósofo que abriu mão de uma carreira de professor em Cambridge para lecionar para crianças no interior da Áustria recorra a tantas cenas de ensino, afinal, Wittgenstein é quem nos instiga a olhar como as coisas realmente ocorrem e como podemos aprender com elas e este pode ter sido uma das motivações do filósofo ao decidir-se pela atividade de ensino com crianças. Embora sua carreira como professor primário, ao que parece, não lhe tenha trazido aquilo que inicialmente esperava, certamente o tempo em que trabalhou com crianças lhe deixou uma inquietação bastante forte, a ponto de trazê-la para os escritos posteriores à experiência.

$$
* * *
$$

Os escritos da maturidade de Wittgenstein contrariam vivamente a noção de que a linguagem é um conjunto de significados estáveis por meio do qual representamos o mundo. Por não se tratar de um conjunto uniforme também não pode ser abarcada por uma teoria, por mais abrangente que esta pudesse ser. Para pensar a linguagem, Wittgenstein nos encoraja a olharmos para ela na ação, no uso, negando, portanto, as análises lógico-filosóficas distanciadas da chamada linguagem ordinária: importa pensar a linguagem na vida. Surge, então, seu 
conceito de jogos de linguagem que, por sua abrangência, é capaz de abarcar a problemática da significação, sempre errática e dependente de um contexto que se mostra tão imprevisível quanto as nossas vidas. É dessa preocupação constante com a composição dos significados que surgem as cenas de alteridade radical nos escritos do Wittgenstein maduro, objeto de estudo da presente pesquisa. 


\section{3}

\section{Perspectivismos}

Ao aceitarmos o convite de Wittgenstein para olhar a linguagem a partir de uma "gramática da ação", na qual o significado se constrói no contexto em acordo com o fluxo da vida, sentimos estremecer cada uma das nossas antigas convicções sobre as relações da palavra com o significado e já, nem relativismo, nem universalismo conseguem dar conta desses complexos pensamentos, que, nos dizeres de Martins (2012: 138), revelam se como "um espírito que desconvida reconhecer em qualquer língua (coletivo) - ocidental ou não - a encarnação de uma cultura igual a si mesma”. A instabilidade daquilo que se quer estável mostra que é preciso ir além da oposição relativo $v s$. verdadeiro para situar toda a necessária mudança que esses pensamentos desencadeiam. Encontramos, no entanto, sobretudo nas cenas de alteridade que aparecem nos escritos maduros de Wittgenstein um tipo de perspectivismo que parece se aproximar do que diz a filosofia de Nietzsche e Deleuze, por exemplo, filósofos que também se inquietam com o devir e com o ser no tempo, indo, portanto de encontro à corrente filosófica tradicional, que busca fixar algo que transcende o mundo.

Falar de perspectivismo é, no entanto, algo ainda bastante desafiador pelo próprio fato de não haver consenso, nem mesmo entre os estudiosos de Nietzsche, do que seria uma Erkenntnistheorie em sua obra, como aponta Mota (2010: 216):

O quebra-cabeça do perspectivismo é marcado por uma incompletude característica, que leva o intérprete a colher em algum lugar fora da imanência dos textos nietzschianos as peças que faltam. Portanto, o trabalho de interpretação do perspectivismo nietzschiano jamais se restringe a mero esforço exegético, tendo, por conseguinte, um aspecto inevitavelmente propositivo, incomum na pesquisa filosófica padrão. Com relação ao perspectivismo, portanto, torna-se particularmente pertinente a ideia de que interpretar é criar.

Da muito comentada transição wittgensteiniana ocorrida entre o Tractatus e as Investigações Filosóficas, talvez os dizeres mais conhecidos sejam os do próprio filósofo, quando fala da passagem do terreno gelado e liso da lógica, que percorrera em suas primeiras obras, ao terreno áspero dos usos contextuais de palavras e expressões da linguagem natural, isto é, daquilo que abordou em seus últimos escritos. De modo geral, não é possível dizer que Ludwig Wittgenstein 
tenha tratado, em algum momento exato de sua produção, especificamente do perspectivismo. É mais coerente, por outro lado, afirmar que esse tema se encontra fragmentado e complementarmente distribuído por suas obras mais tardias (como Conferência sobre Ética, Investigações Filosóficas, Cultura e valor e também Da Certeza), não possuindo uma constituição monolítica, mas formada por uma conjunção de conceitos e noções formuladas em torno de diferentes discussões.

Este capítulo tem por objetivo fazer uma breve retomada das instâncias do pensamento do autor austríaco que podem ser relacionadas ao que, no âmbito da filosofia ocidental, é conhecido como perspectivismo. Para isso, alguns estudiosos e comentadores de sua obra serão mobilizados, principalmente aqueles que buscaram encontrar certa unidade por trás da mencionada dispersão do assunto ao longo da obra wittgensteiniana. O tema não pode deixar de ser caro a este trabalho, uma vez que o perspectivismo (e a alteridade, uma sua companheira) mostra-se fundamental ao tratamento das relações entre as normas e os usos no conjunto das relações culturais e civilizatórias da humanidade.

A visão de linguagem exposta por Wittgenstein no Tractatus, a saber, a de que ela funciona como um cálculo com regras fixas e definidas, é partilhada por boa parte da tradição filosófica ocidental, sendo, ainda que literalmente curta, largamente responsável pela maior parte das teses que surgiram na filosofia da linguagem desde Platão, passando por Santo Agostinho até chegar a Frege. Dada sua extensão, ela chegou a ocultar outras formas de pensar a ideia de uso, significação e regras, ideias nunca propagadas. Não se deve negar a importância que a visão lógica ou essencialista desempenhou no interior da história das ideias, já que foi responsável por inúmeras ramificações tidas como originárias de correntes científicas ainda hoje vigentes; no entanto, deve-se ter em conta que essas correntes apresentam conflitos relacionados à figura do falante (isto é, do sujeito empírico que efetivamente utiliza a linguagem), e à do ouvinte. Sintaxe e lógica mantém uma relação absoluta com a verdade, com o logos.

Queremos, neste ponto do estudo, pela completude que dá às reflexões de Nietzsche (e de Wittgenstein), fazer uma digressão de modo a refletir com Agamben ([1978]2014) sobre o "evento fundador da metafísica", que, nos dizeres do filósofo italiano é o "oblívio da diferença entre língua e fala" e que se funda em dois momentos, os dois remontando aos gregos. O primeiro momento está 
situado entre os gramáticos antigos que iniciavam seus estudos identificando a voz humana como phoné engrámmatos, em latim, "vox quae scribi potest ou quae litteris compreendi potest: voz que se pode escrever, que se pode com-preender, aferrar com as letras" (p. 68, 69), gerando assim uma ilusão de ter capturado a voz e de tê-la inscrito nos grámmata, ilusão que, por sua vez, faz com que a escritura alfabética tenha uma incidência fundamental sobre nossa cultura e sobre a nossa concepção da linguagem. Nasce assim a fonologia, embora nunca se tenha podido chegar a uma real unidade fonológica, pois, até aqui, mostra-se impossível "qualquer sucessão e qualquer subdivisão no ato da fala" do ponto de vista articulatório, já que, de acordo com um filme realizado pelo foneticista alemão Paul Menzerath, os sons da voz humana apresentam-se "como um movimento ininterrupto, no qual os sons não se sucedem, mas entremeiam-se mutuamente". Justamente a percepção dessa impossibilidade de reter a voz de um ponto de vista articulatório ou acústico possibilitou o nascimento da fonologia ou "a desencarnação da língua a partir da voz e a ruptura do vínculo entre língua e voz" (p. 69). O saber, que originalmente encontra-se na voz, procura então seu lugar "reportando-se a uma estrutura incônscia [...]. Os fonemas da fonologia, a estrutura de Lévi-Strauss, a gramática gerativa de Chomsky situam-se todos no Inconsciente" (p. 70).

O segundo momento inscreve-se nas Categorias de Aristóteles quando este distingue coisas que se dizem sem conexão (áneu symplokés): boi, homem, corre, vence, de coisas que se dizem segundo uma conexão (katà symplokén): homem corre, homem vence. Citamos:

Nesta constatação aparentemente óbvia dá-se, porém, um evento de importância fundamental, qual seja, o isolamento na linguagem humana de um dizer sem conexão, de um logos que não se diz em nenhum discurso, mas que, como língua, torna possível a dedução das categorias e a construção da lógica. [...] (É evidente que sem simploké, sem conexão, não se diz, na realidade, nada).

Toda a lógica ocidental, de Aristóteles a Husserl e a Wittgenstein, repousa sobre esta distinção entre uma esfera da língua e uma outra da fala (AGAMBEN, [1978] 2014: 71).

Agamben ressalta que Aristóteles era ainda consciente de que as classificações da lógica valiam apenas no âmbito da distinção entre língua e fala, mas isso vai aos poucos sendo esquecido pela lógica e pela filosofia sucessivas a 
Aristóteles e é por meio desse esquecimento 'que o logos pode afirmar o seu domínio incontestável” (p. 71). E acrescenta:

A redescoberta, na linguística contemporânea e sobretudo na obra de Benveniste, da diferença irredutível que separa o plano da língua e do semiótico do plano da fala e do semântico constitui a base a partir da qual torna-se possível, hoje em dia, um questionamento radical da lógica e da metafísica. Na formulação desta diferença, a ciência da linguagem chega ao seu limite incontornável, além do qual não pode prosseguir sem transformar-se em filosofia (AGMBEN, [1978] 2014: 71).

Voltando à nossa análise sobre um encontro entre Nietzsche e Wittgenstein, vemos que o pensamento essencialista ancorado em um logos que é pura gramática está presente na obra inaugural de Wittgenstein que assim deixa de considerar muitos itens que nas obras mais tardias serão levados em conta, como intencionalidade, distinções entre o que é dito e o que é entendido, o quadro contextual onde as proposições são feitas, além do uso ordinário que se faz das palavras. Sobre esse último, é interessante notar o posicionamento do filósofo no Tractatus, ao defender, em primeiro lugar, a autonomia das regras gramaticais e, em segundo, que são elas as responsáveis pela significação, sem as quais não seria inclusive possível atribuir sentido a uma proposição. Em artigo onde trata da presença da subjetividade na obra do filósofo austríaco, Moreno (2001) fala da completa indiferença quanto ao sujeito empírico que pode ser observada no Tractatus, ressaltando o caráter pouco prático e bastante transcendental das reflexões sobre linguagem então defendidas:

[...] a função transcendental da lógica é exercida no interior da linguagem por um sujeito desprovido de propriedades empíricas, bem como desprovido, também, da propriedade anímica da simplicidade [...] Trata-se de um sujeito que é formal e lógico, do mesmo modo que as proposições significativas em sua articulação interna [...] O sujeito de representações, desejos e pensamentos é empírico; mas, ao exercer a atividade linguística expressiva desses conteúdos mentais, o sujeito surge como pensamento logicamente articulado, a saber, como produtor de regras sintáticas, ou lógicas, de projeção do signo proposicional - surge como produtor de pensamento do sentido. (MORENO, 2001: 237)

Pelo que Moreno alude como articulação interna de proposições - e no que poderia fazer alusão, em contraponto, como articulação externa -, pode-se encontrar relações com o que, mais tarde, será visto como perspectivismo na obra wittgensteiniana: no Tractatus não há mais do que um único e mesmo modo de observação quanto à significação daquilo que é expresso pela linguagem, podendo 
esta se dar apenas se se respeitarem as regras lógicas do pensamento e de verificação de verdade; já para a articulação externa, conforme será observado mais à frente neste capítulo, fatores extrínsecos a essas regras deverão ser levados em consideração, principalmente porque a interpretação e as subjetividades (de quem fala e de quem ouve) aparecerão como vetores decisivos quanto à significação.

Não é possível atribuir a eventos exatos da biografia do filósofo a mudança quanto à visão da linguagem que ocorreu do Tractatus e outros escritos menores produzidos por volta dos anos 1920 até sua volta a Cambridge, depois de passar uma temporada no interior da Áustria onde teve inclusive experiências com ensino para crianças (MONK: 1995), conforme já mencionamos. É conhecida, no entanto, a discussão em torno da ideia de signo e referência que se deu com Frege entre o fim dos anos 1920 e o início dos 1930. Tendo em vista a boa recepção que teve o Tractatus por parte de filósofos ligados ao essencialismo, além, é claro, do próprio cunho essencialista (ou de articulação interna) que esta obra apresentava, seria mais coerente esperar que seu autor tomasse posição ao lado do lógico alemão. No entanto, ocorreu que Wittgenstein tomou um posicionamento autônomo, não aderindo ao modelo fregeano, sendo inclusive bastante conhecida sua afirmação de que Frege, em sua argumentação, jogava com as palavras e deixava, assim, de atingir o cerne da questão em torno do problema referencial. Parece bastante provável que a mudança sugerida tenha se iniciado pelas próprias reflexões suscitadas nessa discussão, principalmente porque as novas publicações, surgidas após este embate, já conterão alguns dos conceitos que, no conjunto de sua obra, serão formadores da ideia de perspectivismo.

Será na Conferência sobre Ética, texto de 1929, que o filósofo, ainda que de modo gradual, irá adicionar às suas reflexões alguns dos fatores externos acima sugeridos. O tratamento comparativo, efetuado pelo filósofo nesse trabalho, entre os enunciados éticos e os empíricos, pode ser considerado o mais importante passo para o amadurecimento de sua filosofia em direção ao perspectivismo. Isso porque, além do procedimento descritivo dos enunciados, realizado em grande medida em sua primeira obra, Wittgenstein passa a considerar o aspecto contextual na comparação entre o que pode ser tomado como empírico e o que é considerado como ético. Para o enunciado empírico, tornam-se relevantes os fatos contextuais, isto é, aspectos exteriores às regras da lógica para a atribuição de 
sentido; enquanto isso, para os enunciados éticos, afirma-se que não há necessidade de contextualização, já que se pretendem como verdadeiros para todas as circunstâncias e funcionam por meio da analogia, isto é, referem-se a outros fatos para influenciar os do contexto.

Assim, quando afirmamos que este homem é um bom pianista, queremos dizer que pode tocar peças de um certo grau de dificuldade com um certo grau de habilidade.(...) e se digo que esta é a estrada correta, significa que é a estrada correta em relação a uma certa meta. Usadas desta forma, tais expressões não apresentam problemas difíceis ou profundos. Mas isto não é o uso que delas faz a ética (WITTGENSTEIN, LE, 1929).

Os enunciados empíricos possuem sentido apenas contextualizadamente, isto é, no interior de determinada situação comunicativa, e os enunciados éticos detêm sentido absoluto, sendo que, por se tratar de analogias, apenas podem ser utilizados em situações onde tal sentido possa se encaixar (Moreno, 2001: 240-1). Aqui, é nítido o questionamento sobre a instabilidade do significado, e sobre a impossibilidade de ancorar a linguagem em fundamentos independentes de um jogo, embora até aqui o filósofo não tenha falado ainda nos jogos de linguagem. A novidade em relação aos escritos anteriores que pode ser vista na Conferência sobre Ética se dá, portanto, quanto à utilização, isto é, quanto ao uso das expressões nos enunciados para a verificação da significação, item que deve ser somado à lógica.

Outra instância do pensamento de Wittgenstein que irá contribuir com o perspectivismo pode ser vista na concepção de paradigma, introduzida no âmbito das reflexões gramaticais do filósofo ao longo dos anos 1930. Antes de tratar especificamente dela, é necessário retomar algo que percorreu suas preocupações no Tractatus: o que se vê por trás dessa obra é uma vontade de analisar os dados de linguagem em um contexto imediato, isto é, sem a interferência de ferramentas ou procedimentos que, ao tratá-los, podem anular suas propriedades imanentes. Ao longo de suas posteriores publicações, vê-se que Wittgenstein percebe que sua busca pela clareza lógica, uma vez calcada numa visão em acordo com a tradição filosófica estabelecida desde Platão, não havia chegado a um ponto de satisfação. Pela dificuldade em exprimir o dado imediato, o filósofo passa, portanto, a considerar a existência e o funcionamento dos paradigmas em suas considerações em torno dos enunciados - algo que, de todo, não se mostra desconexo da recémaplicada relevância do uso. Para uma melhor compreensão, os paradigmas podem 
ser aproximados das convenções usualmente utilizadas na linguagem para fazer referência, por exemplo, a medidas métricas, unidades, modelos padrão para cores, formas, etc. Os paradigmas não são exatamente essas medidas, mas sim algo que as contemple referindo-se antes a tudo aquilo que, no âmbito de uma conversação, se liga a instâncias dadas a priori, ou seja, ao que foge aos dados relativamente significativos. Com mais essa adição às reflexões de linguagem, é possível notar outro passo em direção ao perspectivismo, pois a efetividade dos paradigmas depende tanto de que o sujeito empírico se posicione frente às contingências contextuais quanto que sua alteridade esteja acionada para poder julgar se o outro, nessa relação sempre diádica, pode compreender as convenções socialmente estabelecidas. Moreno (2001), observa que as duas aquisições, da ideia de contexto e de paradigma, devem ser observadas sob um hiperônimo que resume essa fase de amadurecimento da filosofia wittgensteiniana:

\begin{abstract}
No início dos anos 30, Wittgenstein já possui duas ideias fundamentais para sua futura reflexão gramatical: primeira, a importância das comparações analógicas e contextuais entre as diversas aplicações das palavras [...] e, segunda, o conceito de paradigma como elo entre linguagem e o domínio de conteúdos extralinguísticos em geral. A concepção que serve como pano de fundo unificador das duas ideias é a de "praxis da linguagem", como processo de produção de sentido. [...] A praxis da linguagem permite mostrar, claramente, por exemplo, que o uso nominal das palavras é apenas um dos possíveis usos para o nome e não depende, contrariamente ao que afirma no Tractatus, de uma referência que o nome lógico viria a substituir, a saber, o objeto lógico, o logicamente simples. (MORENO, 2001: 243)
\end{abstract}

Talvez uma das imagens mais emblemáticas fornecidas por Wittgenstein, ainda em sua Conferência sobre Ética, que, sem dúvida, possui relações com o perspectivismo, é a da hipotética cabeça de leão que nasce do corpo de uma pessoa $^{14}$. Jacorzynski (2011), em um interessante trabalho em que investiga as

\footnotetext{
14 Todos sabemos o que na vida cotidiana poderia denominar-se um milagre. Obviamente é, simplesmente, um acontecimento de tal natureza que nunca tínhamos visto nada parecido com ele. Suponham que este acontecimento ocorreu. Pensem no caso de que em alguém de vocês cresça uma cabeça de leão e comece a rugir. Certamente isto seria uma das coisas mais extraordinárias que sou capaz de imaginar. Tão logo nos tivéssemos recomposto da surpresa, o que eu sugeriria seria buscar um médico e investigar cientificamente o caso e, se não pelo fato de que isto causaria sofrimento, mandaria fazer uma dissecação. Aonde estaria então o milagre? Está claro que, no momento em que olhamos as coisas assim, todo o milagroso haveria desaparecido; a menos que entendamos por este termo simplesmente um fato que ainda não tenha sido explicado pela ciência, coisa que significa por sua vez que não temos conseguido agrupar este fato junto com outros num sistema científico. Isto mostra que é absurdo dizer que "a ciência provou que não há milagres". A verdade é que o modo científico de ver um fato não é vê-lo como um milagre. Vocês podem imaginar o fato que puderem e isto não será em si milagroso no sentido absoluto do termo. Agora
} 
contribuições da filosofia wittgensteiniana à antropologia e às ciências sociais, aborda o exemplo da cabeça de leão ${ }^{15}$ como um meio pelo qual o filósofo procura comparar as linguagens religiosas em contraposição às científicas. De acordo com o antropólogo, há três perspectivas que podem ser colocadas em jogo diante do brotamento da cabeça, sendo que elas se relacionam de maneira excludente. A primeira delas seria a compreensão do fato pelo viés científico, o que eliminaria a aceitação de um milagre: Wittgenstein afirma que, refeito do espanto pelo brotamento da cabeça, iria a um médico para que este investigasse as razões do surgimento. A segunda perspectiva é a de certa hesitação entre a compreensão científica e a religiosa, afirmando-se que um milagre configura-se como tal apenas enquanto não tenha recebido uma explicação científica, sendo, dessa forma, uma visão relativa. Já a terceira delas seria a aceitação do brotamento como milagre, isto é, puramente a visão religiosa (JACORZYNSKI, 2011: 193). Com o exemplo do brotamento da cabeça de um leão, Wittgenstein conclui que não há um sentido absoluto para o termo milagre e que todas as vezes que tentarmos dar um sentido absoluto às proposições da ética e da religião estaremos lutando contra os limites da linguagem e que, por mais que busquemos exemplos para encontrar o sentido absoluto, com a linguagem apenas podemos descrever fatos. $\mathrm{O}$ valor absoluto que tanto buscamos está além dos limites do mundo, portanto, além dos limites da nossa linguagem.

Tendo em vista as noções até aqui apresentadas acerca das reflexões de linguagem de Wittgenstein, é possível passar às ideias que, de maneira determinante, configuraram com maior consistência os termos para um perspectivismo wittgensteiniano. Ao longo dos anos 1930, principalmente nos materiais datilografados e no Brown Book, o filósofo passa a recorrer, cada vez mais frequentemente, à noção de semelhanças de família. Embora tenha sido formulado de maneira mais concisa nas Investigações Filosóficas (PU §§ 65, 66, 193, 210), esse conceito serviu, desde a polêmica com Frege, como uma primeira forma de contraponto aos ideais lógico-essencialistas, ainda que tal não fosse a

nos damos conta de que temos utilizado a palavra "milagre" tanto num sentido absoluto como num relativo. (WITTGENSTEIN, LE, 1929) 
intenção manifesta do filósofo. As semelhanças de família compreendem palavras e expressões ligadas contextualmente: encontra-se nessa noção, se não a principal, uma das mais importantes fontes do perspectivismo wittgensteiniano. Da fórmula clássica, e cara ao essencialismo, "definitio fit per genus proximum et differentia specifica" que visava atribuir definições de caráter lógico às palavras, a então recente ideia de semelhanças de família vem a englobar todas as espécies de proximidades à explicação (e não mais à definição) de uma expressão. É fácil perceber a estreita relação entre essa ideia e a já comentada ideia da visão sinóptica. Tanto uma quanto outra estão relacionadas aos princípios mais característicos da filosofia de Wittgenstein, a recusa pelas respostas generalizantes, seu completo afastamento de definições totalizantes, o que se traduz na ausência de teorias em seus escritos.

Em retomada às abordagens antropológicas sobre os rituais de sacrifício de algumas sociedades, Jacorzynski (2011) fala do caráter perspectivista que a noção de semelhança de família wittgensteiniana trouxe tanto para o conjunto das ciências humanas quanto para a antropologia. Procurando tratar da consideração da subjetividade do antropólogo enquanto fator a ser adicionado às observações dos rituais de uma tribo, Jacorzynski menciona importantes passagens das Observações Filosóficas e de outra obra tardia de Wittgenstein, as Investigações:

El concepto de la representación perspícua se no aparece em diferentes contextos em la obra de Wittgenstein. Em las Observaciones filosóficas, por ejemplo, Wittgenstein habla sobre representaciones del espacio de colores em uma imagen del octaedro, com los colores puros en los vértices, y observa que tal representación es a priori, gramática, es decir, no se establece a partir de ningún experimento. "La representación a la que da lugar el octaedro es uma representación perspícua de las reglas gramaticales", y agrega: "El principal problema con nuestra gramática es que no tenemos una representación perspicua de ella" [...] Em las Investigaciones filosóficas el concepto aparece nuevamente em el mismo contexto: "Una fuente principal de nuestra falta de comprensión es que no vemos sinópticamente el uso de nuestras palabras". [...] A nuestra gramática le falta visión sinóptica" (IF: §122). (JACORZYNSKI, 2011: 195)

É possível perceber, pelas várias metáforas e analogias visuais presentes nos excertos wittgensteinianos mencionados por Jacorzynski, a forte presença do que se pode caracterizar como perspectivismo. Se retornarmos à fórmula clássica de definição, vemos que toda a metáfora visual de Wittgenstein serve para introduzir novos matizes às considerações em torno das expressões, ao invés de procurar o que antes julgava ser possível encontrar, isto é, a cor típica e o tom próprio de 
cada conceito. A visão sinóptica a que se refere o filósofo não passa de uma visão estendida da nova apreensão filosófica que propõe, e não a até então dominante, que era a visão pontual do essencialismo. É o momento em que o perspectivismo passa a frequentar o interior de suas inquietações filosóficas.

\section{1}

\section{O perspectivismo na filosofia: Nietzsche e Wittgenstein}

O presente tópico tem como propósito dar a ver uma aproximação entre os trabalhos de filósofos que reconhecidamente estão ligados à ideia de perspectivismo, como Nietzsche e Deleuze, e a filosofia wittgensteiniana, aproximação que se revela fecunda no que se refere à composição amadurecida da filosofia de Wittgenstein, objeto de interesse para a presente análise. Tais semelhanças que os autores guardam são evidenciadas a partir da pluralidade de perspectivas, no que vão além das correntes mais tradicionais da filosofia ocidental.

É Wittgenstein mesmo quem, em um texto datado de 1938, observa que o conjunto de sua obra pode ser encarado como uma "aproximação de Nietzsche", ao propor:

Se eu não pretendo apresentar um pensamento mais correto, mas uma outra perspectiva de pensamento, então meu propósito é uma "transvaloração dos valores", e eu me aproximo de Nietzsche, e, também, desta maneira, de que, na minha opinião, o filósofo deve ser um poeta ${ }^{16}$.

Entende-se perspectivismo como a designação para uma suposta teoria do conhecimento de Nietzsche, partindo das palavras "não há fatos, apenas interpretações", para resumir o pensamento central da obra desse autor. Mota (2010) atenta para o fato de que colocar o perspectivismo como teoria do conhecimento, principalmente daquela que se pode encontrar em Nietzsche, redunda em dois problemas: o autor questiona se, nos escritos nietzschianos, existiria a possibilidade de afirmar que resida, ali, algo como uma teoria do

\footnotetext{
16 "Wenn ich nicht ein richtigeres Denken, sondern eine [andere| neue] Gedankenbewegung lehren will, so ist mein Zweck eine 'Umwertung von Werten' und ich komme auf Nietzsche,sowie auch dadurch, daß meiner Ansicht nach, der Philosoph ein Dichter sein sollte",WITTGENSTEIN, L. Wittgenstein's Nachlass: The Bergen Electronic Edition,MS142, 145r. In:, CARVALHO (2013: 200).
} 
conhecimento (Erkenntnistheorie). A hipótese afirmativa implicaria no segundo problema, trazendo a questão sobre a forma como essa teoria poderia se inserir no debate epistemológico contemporâneo.

Analisando o termo perspectivismo, principalmente a partir da ampliação de seu uso, percebe-se que o termo conquistou uma vasta diversidade de sentidos, o que se mistura ao próprio significado que o termo se propõe a implicar. A importância do tema do perspectivismo em Nietzsche é inquestionável e altamente fértil, como se pode observar dada a proliferação de trabalhos que dele derivam em todos os ambientes onde sua filosofia é motivo de investigações. O legado de Nietzsche, no entanto, é sobretudo caro àqueles que pensam a linguagem.

Como Mota (2010) observa, dentre suas várias aplicações, o perspectivismo consiste em uma afirmação da pluralidade de sentidos, isto é, alude a uma polissemia irredutível. Retoma-se o aforismo de Nietzsche, Nosso novo "infinito", que justifica a utilização de "perspectivismo" para diversos empregos.

Penso que hoje, pelo menos, estamos distanciados da ridícula imodéstia de decretar, a partir de nosso ângulo, que somente dele pode-se ter perspectivas. O mundo tornou-se novamente 'infinito' para nós: na medida em que não podemos rejeitar a possibilidade de que ele encerre infinitas interpretações ${ }^{17}$.

Entretanto, da mesma forma que Nietzsche preconizou a investigação genealógica para buscar a determinação de filiações entre tipos, e não uma primeira origem dos conceitos, a genealogia do perspectivismo é antecedente à tradição nietzschiana. Kant, em sua filosofia transcendental, concretiza a figura e o conceito da autoafirmação, quando na Crítica da Razão Pura, afirma que os físicos, os que estudam as ciências da natureza

Compreenderam que a razão só entende aquilo que produz segundo os seus próprios planos. A razão tem de tomar a dianteira com princípios que determinam os seus juízos, segundo leis constantes e deve forçar a natureza a responder às suas interrogações, em lugar de se deixar guiar por esta. A não ser assim, as observações feitas ao acaso, realizadas sem plano prévio, não se ordenam segundo a lei necessária, que a razão procura e de que necessita ${ }^{18}$.

Essa apresentação, como um epítome da autoafirmação da modernidade, apresenta a crítica kantiana de que a razão não é mais do que uma operação de dominação do representado pela representação, e na modernidade, o ser aparece

\footnotetext{
${ }^{17}$ FW/GC 374, KSA 3.627 In: MOTA (2010, s.p.).

${ }^{18}$ Crítica da Razão Pura, Prefácio da $2^{\text {a }}$ Ed.(1787) p. 27 Ed. Martin Claret (Trad. Alex Marins).
} 
ao sujeito auto afirmativo. Tal assertiva é comparável às reflexões nietzschianas e heideggerianas, por exemplo, em suas críticas ao formalismo, como a representação de uma dominação contra a vida e o ser, denunciando-se a abstração.

O surgimento do sistema monadológico criado por Leibniz, durante o período moderno, apresenta uma genealogia do termo "perspectivismo", especialmente em relação à representação da racionalidade leibniziana. Isto é, o autor defende que nunca se está em um mundo de acontecimentos com pesos iguais, como se eles existissem indiferentes em relação ao sujeito. Dentre outros princípios discutidos pelo filósofo, o "princípio da noção de predicado" garante que em toda proposição verdadeira e afirmativa, seja ela contingente ou necessária, universal ou particular, o predicado participa da noção de sujeito: tal como uma semente, contém toda a possibilidade da árvore, uma mônada substância simples e indivisível em partes, portanto - contém todo acidente possível em seu percurso. Combate, dessa forma, o cogito cartesiano e mecanicista, e concomitantemente defende a ideia de um mundo constituído por multiplicidades, sendo impossível à razão abarcar o conhecimento.

Ao discutir a genealogia do termo, Mota (2010) cita como exemplo o volume organizado por V. Gerhardt e N. Herold, Perspektiven des Perspektivismus, obra que revela a fecundidade da noção em autores e campos distintos da investigação filosófica, embora seja reconhecida a influência nietzschiana para a disseminação do termo. Mota (2010) defende que o perspectivismo nietzschiano identificado com a filosofia da maturidade de Wittgenstein apoia-se sobre a definição de perspectivismo pragmático, utilizandose de leituras que ele considera como pragmáticas em relação ao perspectivismo, partindo das proposições de Arthur Danto, em Nietzsche as philosopher (1965).

A preocupação de Nietzsche com a linguagem consiste na principal razão para a aproximação entre o filósofo e a filosofia analítica, já que seus escritos criticam e atacam tanto o essencialismo quanto o universalismo em sua pretensão de referenciar os fatos - ou seja, é uma pretensão querer que os fatos se reduzam aos modos de expressão. Isso implica que os homens seriam seduzidos pela gramática da linguagem que falam, e de maneira implícita, esses indivíduos acreditam estar realmente descrevendo o mundo através dessa gramática, quando 
o mundo, da forma como é concebido, consiste somente em um reflexo da estrutura de sua língua.

A abordagem nietzschiana, então, não seria a de tentar resolver os problemas clássicos da filosofia, mas, sim, dissolvê-los, para que eles se tornem destituídos de sentido, até que se revelem como pseudoproblemas, mediante uma espécie de terapia da linguagem. Essa terapia está presente no sentido da frase enunciada por Nietzsche em Crepúsculo dos ídolos, que determina: "receio que não nos livraremos de Deus, pois ainda cremos na gramática" e quanto a isso são bastante esclarecedoras as reflexões de Agamben trazidas neste capítulo. A leitura pragmática do perspectivismo, portanto, envolve uma aproximação com Wittgenstein, pois, para este, a filosofia diz respeito a uma luta contra o enfeitiçamento de nosso entendimento pelos meios da nossa linguagem.

No § 109 das Investigações, Wittgenstein sinaliza que os problemas filosóficos não são empíricos, mas podem ser resolvidos por meio de um exame do trabalho de nossa linguagem, de forma que este possa ser reconhecido e, em certa medida, resolvido, se lutamos contra o impulso de mal compreendê-lo. Dessa maneira, os problemas são resolvidos não pelo acúmulo de novas experiências, mas pela combinação do que é já há muito tempo conhecido. O argumento tem continuidade no parágrafo seguinte, quando o pensamento wittgensteiniano pondera que a ideia de que a linguagem seja algo único apoia-se na produção das ilusões gramaticais, e os problemas, então, nasceriam de uma má interpretação de nossas formas linguísticas.

Nos dizeres de Nietzsche, por sua vez, a sedução da linguagem (o que Wittgenstein entende como ilusões gramaticais) leva os sujeitos a substancializarem os itens linguísticos, acreditando que o objeto ou o ser são mais que meras funções da linguagem, entidades substanciais (MOTA, 2010). Além disso, a semelhança entre as proposições nietzschianas e wittgensteinianas também tem continuidade no pluralismo linguístico defendido por ambos, pensando que perspectivas podem ser aproximadas, de forma pertinente. Os jogos de linguagem e as formas de vida de Wittgenstein podem ser comparados aos tipos de Nietzsche. Ambos os autores criam uma abordagem da linguagem, em termos pragmáticos, colocando-a como uma prática, definindo seu significado, bem como o conceito de verdade, como sujeitos aos termos de uso. 
Em A Gaia Ciência, Nietzsche transforma o constitutivo em regulador, pois está interessado em pluralizar o regulador ao infinito, como uma perspectiva, já que o constitutivo era, ainda, uma estrutura rígida e universal. Exemplo disso está no trecho: "O mundo voltou a tornar-se para nós infinito", quando o autor compreende uma infinidade de interpretações.

Carvalho (2010) propõe um retorno ao principal interlocutor de Nietzsche no projeto lógico de Platão. Discute-se, portanto, uma perspectiva do platonismo, quando se estabelece o conceito de falsidade como o oposto da verdade, o que esvaziaria o conceito de verdade de sentidos ontológicos. Existe um paradoxo em tal construção, pois ao identificar a verdade ao ser, em sentido ontológico, na proposição do contrário, o falso estaria relacionado ao não-ser, e como não se pode dizer o não-ser, o discurso falso torna-se impossível, de forma que todo discurso seria verdadeiro ou sem sentido.

Ao mesmo tempo, o esvaziamento de sentido ontológico do conceito de verdade possibilita a compreensão do discurso falso como alteridade, o que elimina o paradoxo. Carvalho explana ainda sobre o conceito de verdade como a descrição de uma relação lógica entre linguagem e mundo, em que a verdade aparece como uma relação de adequação entre linguagem e mundo e em que o oposto da verdade é a falsidade, na proposição de que falsidade implica em dizer algo diferente daquilo que é - dizer que é aquilo que não é, ou ainda, dizer que não é aquilo que é (CARVALHO, 2010: 202).

Em Sobre verdade e mentira no sentido extramoral, Nietzsche contraria a referida concepção de verdade, confrontando, inclusive a noção cartesiana de verdade e erro, quando esta concepção associa o conceito de verdade a um conteúdo epistemológico. Além disso, Nietzsche contraria também a noção de ilusão desenvolvida por Kant, a qual se contrapõe à verdade em sua dialética transcendental.

A concepção nietzschiana da verdade é entendida como um conceito atuante no domínio da linguagem, de forma a esvaziar tanto o conteúdo ontológico, quanto o epistemológico, contradizendo a acepção de mentira em um recorte extramoral. A constituição da linguagem, então, fornece o lugar para que o debate sobre a verdade se situe entre as relações, ações e interesses humanos. 
Em 1873, a partir da publicação de Sobre verdade e mentira no sentido extra-moral, tal contestação de Nietzsche torna-se mais clara, quando o autor descreve a delimitação conceitual através da "igualação do não igual". Para tornar-se conceito, a palavra necessita tomar distância da vivência primitiva a que esteve associada de início, passando a nomear "um sem número de casos mais ou menos semelhantes" ${ }^{19}$, o que faz deles, desiguais, portanto (CARVALHO, 2010: 203).

O conceito, então, é entendido como o resultado de um processo de construção. Pressupondo que tal processo não resulta de essências ou de quaisquer unidades exteriores a ele mesmo, isso mostra uma arbitrariedade em sua determinação. Para justificar que nada, nas vivências primitivas, determina a constituição de conceitos ou seus limites, Nietzsche apropria-se de dois exemplos fundamentais. O primeiro dedica-se a uma observação da análise de Goethe, sobre a metamorfose das plantas, em específico, referenciando-se à concepção da unidade dos conceitos da botânica, referindo-se a uma planta primordial, bem como às leis da metamorfose, como responsáveis pela constituição das plantas.

Todo conceito surge da postulação da identidade do não-idêntico. Assim como é evidente que uma folha não é nunca completamente idêntica à outra, é também bastante evidente que o conceito de folha foi formado a partir do abandono arbitrário destas características particulares e do esquecimento daquilo que diferencia um objeto de outro (NIETZSCHE: [1873] 2001: 11).

Nietzsche ressalta o quão arbitrário é esse processo que abandona a particularidade, pois, como demonstra o filósofo, uma folha nunca é inteiramente igual à outra, e da mesma forma, o conceito de folha é formado por um abandono arbitrário das diferenças individuais, ao se esquecer do que implica o distintivo. O segundo exemplo pode ser considerado um aprofundamento do primeiro por questionar um conceito relacionado às ações humanas.

Dizemos de um homem que ele é honesto; perguntamos a nós mesmos porque ele agiu hoje tão honestamente. Respondemos geralmente que foi por causa de sua honestidade. Honestidade! Isto significa novamente dizer que a folha é a causa das folhas. Não sabemos mesmo absolutamente nada de uma qualidade essencial

\footnotetext{
19 "Pensemos ainda, em particular, na formação dos conceitos. Toda palavra torna-se logo conceito justamente quando não deve servir, como recordação, para a vivência primitiva, completamente individualizada e única, à qual deve seu surgimento, mas ao mesmo tempo tem de convir a um sem número de casos, mais ou menos semelhantes, isto é, tomados rigorosamente, nunca iguais, portanto, a casos claramente desiguais. Todo conceito nasce por igualação do não igual" (NIETZSCHE, [1873] 2001:11).
} 
chamada honestidade, no entanto conhecemos inumeráveis ações individualizadas e por conseguinte dessemelhantes, mas que postulamos como idênticas ao deixarmos de lado o que as torna diferentes; assim, designamos as ações honestas a partir das quais afinal formulamos uma qualitas occulta com o termo: a honestidade (NIETZSCHE: [1873] 2001: 11).

Partindo desse raciocínio, Nietzsche descreve a forma como o conceito de honestidade foi construído, pois, a princípio, não se sabe de uma qualidade essencial que pudesse ser conhecida como "a honestidade". O que se sabe são as ações individualizadas que, por serem individualizadas, são desiguais. Elas são igualadas justamente pelo abandono do desigual, e posteriormente são designadas como ações honestas, e a partir disso, formula-se uma ilusória qualitas occulta denominada de "a honestidade".

Carvalho (2010: 205) observa a recusa de qualquer essência referida pelos conceitos. Sendo assim, a unidade que se associa aos conceitos foi construída a partir de outro critério, não relacionado ao ajuste da objetividade. Assim, retomase a tradição kantiana e a herança hegeliana, ao comentar o esquecimento do processo da origem da constituição do conceito. A objetividade é apresentada aos homens como uma intrincada rede de conceitos moldados por esses próprios homens que a utilizam para compreender suas ações e experiências.

Essas considerações contextualizam a discussão sobre a concepção da verdade que, concebida no domínio da linguagem, não se apresenta como um ajuste a ela, ilustrada pelos questionamentos de Nietzsche ([1873]2001: 13-17) acerca do que seria a verdade, ou seja, metáforas que se tornaram gastas, ou então, um conjunto de antropomorfismos. O que inicialmente era apenas um conjunto de relações humanas foi enfatizado durante um período tão longo que seu caráter "poético" foi esquecido. O que se diz como verdade são metáforas enfeitadas durante muito tempo e que assim disfarçadas parecem sólidos e obrigatórios conceitos.

O conceito de verdade, construído nesse contexto, apresentando-se em meio ao discurso, pressupõe a linguagem. Isto significa que a construção da linguagem não ocorre como resposta às coisas, ela não é um ajuste aos conceitos, tampouco existe para se autorregular segundo uma ontologia pressuposta e, assim sendo, possa dizer o que é. A construção da linguagem responde a um interesse humano que é móvel e varia de acordo com as circunstâncias, e a verdade é construída, 
então, partindo desses interesses humanos, que foram apresentados como sólidos ou obrigatórios.

Para compreender a semelhança guardada entre os debates realizados por Nietzsche e a construção da obra wittgensteiniana, foi preciso percorrer esse caminho, principalmente no que se refere às pretensões humanas sobre a linguagem, pois esses pensadores percebem um vício de responder às nossas inquietações filosóficas por meio de critérios de adequação da linguagem ao mundo, tornando-se necessário, nesse caso, descobrir um papel para a linguagem.

A transição wittgensteiniana entre o Tractatus e as Investigações é explicada como uma passagem da afirmação para a recusa do conceito platônico da verdade, o que redundou no abandono de qualquer determinação sobre a significação e de qualquer teorização da linguagem. A concepção acerca da linguagem altera-se de tal forma, a ponto de negar não apenas que ela remeta a fatos e objetos, mas que não seja possível pensá-la como uma denominação de percepções e fenômenos, recusando a possibilidade de remeter a linguagem a uma fenomenologia $(\mathrm{Z}, \S \S$ $55-62)$.

Em razão disso, nas Investigações, entre os parágrafos 1 e 88, Wittgenstein tece, como já vimos, sua longa e incisiva contraposição à imagem da linguagem por meio da visão agostiniana, que aparece citada na abertura do texto. Sua abordagem apresenta uma perspectiva mais ampla, pressupondo que as palavras não significam objetos, ainda que exista a possibilidade de construir uma relação entre estes.

Para Wittgenstein, o grande equívoco do entendimento da linguagem como representação está em supô-la como capaz de teorizar o que quer que seja, inclusive os problemas filosóficos, como se fosse possível uma correlação de significações. Assim, o filósofo, embora, como vimos no capítulo da fundamentação teórica, parta da imagem de Agostinho, combate a visão essencialista. A pertinência da discussão foca-se na descrição dos usos que se faz das palavras, no que é possível fazer com elas, como é possível abdicar da explicação platônica quando olhamos para o estranho que está tão próximo a nós.

Durante essa reflexão, Wittgenstein parece concluir que não há nada entre a linguagem e seu uso. Questionar a um indivíduo o significado de uma palavra equivale, então, a perguntar se ele sabe como fazer uso dessa palavra. Portanto, o aprendizado de uma linguagem seria resultado de um treinamento, a contrapartida 
do uso, não de uma explicação, como ocorre no caso em que se concebe a linguagem como um conhecimento anterior à ação: uma linguagem não é uma teoria (CARVALHO, 2007: 64).

E isso é verdade. - Em vez de indicar algo que é comum a tudo aquilo que chamamos de linguagem, digo que não há uma coisa comum a esses fenômenos, em virtude da qual empregamos para todos a mesma palavra, -mas sim que estão aparentados uns com os outros de muitos modos diferentes. E por causa desse parentesco ou desses parentescos, chamamo-los todos de "linguagens". (IF § 65).

O cerne desse questionamento é identificado como extremamente próximo daquele encontrado em Sobre Verdade e Mentira, de Nietzsche (CARVALHO, 2010: 208), quando há a recusa dos limites claros do conceito. Sendo assim, o conceito de linguagem só encontraria um conjunto de coisas agregadas, como uma certa "semelhança de família", que diz respeito a uma série de sobreposições e similaridades que se entrecruzam. Dessa maneira, evidencia-se que o nome não remete a nenhum objeto que ele signifique, ou então, não remete a outros correlatos desse objeto. Explicita-se, também, que não existe objeto referido, assim como não existe uma unidade delimitada precisamente, em razão do uso que se tem de conceito. Carvalho (2010: 209) ressalta que as semelhanças de família são constituídas apenas em meio às circunstâncias e intenções presentes no uso, e na maneira como cada indivíduo lida com seus exemplos, portanto, as semelhanças não podem ser naturalizadas ou delimitadas de maneira rígida.

Assim, Wittgenstein resgata o conceito de "folha", remetendo à análise nietzschiana da referência a Goethe, na metamorfose das plantas. O comentário wittgensteiniano explora a dificuldade de estabelecer uma concepção da significação do conceito, sem fixar uma unidade, seja ao referir-se a uma essência comum a todas as folhas, ou uma forma de delimitação extencional. Logo, a unidade da folha é fixada por meio da forma como o conceito foi usado, por repetidas vezes:

Se me mostrarem diferentes folhas e me disserem: "Isto chama-se 'folha", então adquiro um conceito da forma de folha, uma imagem dela no espírito. - Mas que aspecto tem pois a imagem de uma folha que não mostra uma forma determinada, mas sim 'o que é comum a todas as formas de folha'? Que tom de cor tem o 'modelo no meu espírito' da cor verde - daquilo que é comum a todos os tons de verde?

Mas não poderia haver tal modelo 'geral'? Algo como um esquema de folha, ou um modelo de verde puro?” - Certamente! Mas que esse esquema seja 
compreendido como esquema, e não como forma de folha determinada, e que um quadrinho de verde puro seja compreendido como modelo de tudo aquilo que tem a cor verde e não como modelo para o verde puro - isto depende do modo de emprego desses modelos. (IF § 73).

Essa passagem pontua a dificuldade de estabelecer uma ideia geral de folha, assim como sua relação com os casos particulares. $\mathrm{O}$ argumento demonstra que a suposição de que se tenha um modelo de folha não é um objeto de natureza específica, ou seja, o modelo de uma folha é, ele mesmo, uma folha, portanto, o modelo consiste no uso que se faz do objeto, pois em quaisquer outras circunstâncias onde não houvesse o interesse humano, ele seria apenas um objeto ordinário.

Carvalho (2010: 210) reaproxima as considerações de Wittgenstein e de Nietzsche, em razão de ambos se colocarem frente ao problema de indicar a que o processo de constituição da significação e da linguagem responde, já que recusam a noção da linguagem como uma referência à objetividade que lhe seria anterior. A essa questão, Wittgenstein propõe que, ao imaginar uma linguagem, imagina-se uma forma de vida, que desempenha o papel de determinar o processo de constituição da significação e da linguagem.

Apesar de iniciar tais reflexões a partir das Investigações, Wittgenstein aprofundará, como vimos, suas ideias nos textos de sua filosofia mais madura, como o conjunto de proposições publicadas em Da Certeza, nos quais se dedica a apresentar a linguagem como um sistema, onde não se concebe que existam proposições básicas, que se justifiquem a partir da experiência ou de percepções sensíveis, ou quaisquer outras referências a algo exterior à linguagem. O processo de justificação da linguagem chega a um fim que, para o filósofo,

a fundamentação, a justificação da evidência tem um fim - mas o fim não é o fato de certas proposições se nos apresentarem como sendo verdadeiras, isto é, não se trata de uma espécie de ver da nossa parte; é o nosso atuar que está no fundo do jogo da linguagem. (UG § 204).

Ao fim da cadeia de justificações, a forma particular de agir e julgar é que se apresenta como verdadeira. A estrutura da linguagem remete às ações, às relações humanas, que exercem o papel de grau último na cadeia de argumentos, e que de maneira transitória, será considerado como sólido e certo, pois "tão certo que nem se apresenta para nós como uma certeza: é simplesmente assim que fazemos", onde já é irrelevante falar de justificação (CARVALHO, 2010: 212), pois a 
dificuldade está na compreensão da falta de fundamento das convicções (UG § 166).

Para se falar da verdade, é preciso estar no interior de um sistema de linguagem, uma vez que a verdade se diz dentro do contexto de uma linguagem. Esta, diz respeito a uma forma de vida, e à própria linguagem, ou seja, fora dela não é pertinente falar de verdade ou falsidade. Wittgenstein mesmo apresenta a objeção, formulada em seu texto, ao questionar se não haveria nenhuma verdade objetiva, ou se não é verdadeiro nem falso que alguém tenha estado na Lua (UG § 108; CARVALHO, 2012: 213).

E a resposta nos repete essa dependência que a afirmação de algo como verdadeiro tem com uma linguagem particular, e, portanto, com uma forma de vida particular: "Se estamos a pensar dentro do nosso sistema, então é certo que nunca ninguém esteve na Lua". A "gramática", em meio à qual a verdade se coloca, é autônoma em relação à objetividade da "coisa em si", mas não em relação às formas de vida e aos interesses humanos (ainda que estes precisem de aspas, pois não se deve cometer o equívoco de produzir uma naturalização desse conceito de "interesse") (CARVALHO, 2010: 214).

A proposição, portanto, da constituição da linguagem a entende como uma prática que cuida de si própria, enquanto ação que não responde a outra coisa senão a si mesma. Logo, quando debate a verdade, Wittgenstein afasta-se da tradição filosófica ocidental e aproxima-se das delimitações nietzschianas propostas em Sobre a Verdade e a Mentira.

\section{2}

\section{O perspectivismo ameríndio segundo Eduardo Viveiros de Castro}

O presente tópico pretende elaborar uma reflexão à luz da produção etnofilosófica de Eduardo Viveiros de Castro, valendo-se dos aspectos apresentados acerca da noção de perspectivismo, enquanto articula estes escritos com a filosofia de Wittgenstein.

Para dar início ao desenvolvimento das considerações sobre o pensamento de Eduardo Viveiros de Castro, é necessário, em um primeiro momento, abordar os conceitos de multinaturalismo e perspectivismo ameríndio, desenvolvidos pelo antropólogo (VIVEIROS DE CASTRO, 2011; 2008; 2002; 1998; 1996). 
Para Viveiros de Castro (2008, p. 75), a expressão "perspectivismo ameríndio" consiste em um rótulo forjado a partir de um conceito da filosofia ocidental por seu caráter qualificador para um determinado aspecto característico das plurais cosmologias ameríndias em que se compreende que o mundo é povoado de muitas espécies de sujeitos que não se limitam aos humanos, todos com consciência e cultura. Além disso, essas espécies veem a si mesmas e às outras de modo singular, assunto que será discutido no presente tópico.

Em Perspectivismo e multinaturalismo na América Indígena, Viveiros de Castro (2011) dispõe sobre a necessidade de uma rigorosa crítica etnológica caso se deseje realizar uma distinção entre Natureza e Cultura para a descrição de dimensões pertencentes às cosmologias não ocidentais.

Tal crítica [à distinção clássica entre Natureza e Cultura], no caso presente, exige a dissociação e redistribuição dos predicados subsumidos nas duas séries paradigmáticas que tradicionalmente se opõem sob os rótulos de Natureza e Cultura: universal e particular, objetivo e subjetivo, físico e moral, fato e valor, dado e construído, necessidade e espontaneidade, imanência e transcendência, corpo e espírito, animalidade e humanidade, e outros tantos. Esse embaralhamento das cartas conceituais leva-me a sugerir o termo multinaturalismo para assinalar um dos traços contrastivos do pensamento ameríndio em relação às cosmologias "multiculturalistas" modernas. Enquanto estes se apoiam na implicação mútua entre unicidade da natureza e multiplicidade das culturas - a primeira garantida pela universalidade objetiva dos corpos e da substância, a segunda gerada pela particularidade subjetiva dos espíritos e do significado -, a concepção ameríndia suporia, ao contrário, uma unidade do espírito e uma diversidade dos corpos. A cultura ou o sujeito seriam aqui a forma do universal; a natureza ou o objeto, a forma do particular (VIVEIROS DE CASTRO, 2011: 348-349).

O conceito de multinaturalismo criado pelo antropólogo relaciona-se diretamente às cosmovisões dos povos ameríndios, inseridos em um contexto de entendimento não ocidental. Em seus trabalhos, portanto, Eduardo Viveiros de Castro desenvolve uma nova suposição para explicar as mitologias ameríndias, contrariando a clássica doutrina do multiculturalismo estabelecida dentro da antropologia (SOUZA, 2014: 2).

Ao afirmar que ideias multiculturalistas "se apoiam na implicação mútua entre unicidade da natureza e multiplicidade das culturas", Viveiros de Castro (2011: 349) tece uma contraposição, por meio da criação da noção multinaturalista, que defende a existência de uma mesma unidade cultural em face de uma diversidade de corpos. Enquanto o multiculturalismo defende apenas uma natureza frente a uma variedade de sujeitos, o multinaturalismo reflete a 
existência de uma unidade de fundo que abarca todos os seres diante de uma natureza plural.

A inversão proposta pelo antropólogo é essencial para repensar as categorias de Natureza e Cultura, quando inseridas no pensamento ameríndio, pois essas categorias não se configuram da mesma forma que no pensamento ocidental, uma vez que as cosmovisões ameríndias são designadas em contextos relacionais, pontos de vista e perspectivas.

É a partir dessas orientações que a discussão se volta para o conceito de humano, buscando o entendimento para as formas como os povos ameríndios compreendem a condição de humanidade, além da maneira de ver os próprios animais ou outras subjetividades que estão presentes em seu universo, tais quais os espíritos, deuses, fenômenos ou habitantes de níveis cósmicos distintos.

Tipicamente, os humanos, em condições normais, veem os humanos como humanos e os animais como animais; quanto aos espíritos, ver estes seres usualmente invisíveis é um signo seguro de que as "condições" não são normais. Os animais predadores e os espíritos, entretanto, veem os humanos como animais de presa, ao passo que os animais de presa veem os humanos como espíritos ou como animais predadores: "O ser humano se vê a si mesmo como tal. A Lua, a serpente, o jaguar e a mãe da varíola o veem, contudo, como um tapir ou um pecari, que eles matam", anota Baer (1994: 224) sobre os Machiguenga. Vendo-nos como não-humanos, é a si mesmos que os animais e espíritos veem como humanos. Eles se apreendem como, ou se tornam, antropomorfos quando estão em suas próprias casas ou aldeias, e experimentam seus próprios hábitos e características sob a espécie da cultura: veem seu alimento como alimento humano (os jaguares veem o sangue como cauim, os mortos veem os grilos como peixes, os urubus veem os vermes da carne podre como peixe assado etc.), seus atributos corporais (pelagem, plumas, garras, bicos etc.) como adornos ou instrumentos culturais, seu sistema social como organizado identicamente às instituições humanas (com chefes, xamãs, ritos, regras de casamento etc.). Esse "ver como" refere-se literalmente a perceptos, e não analogicamente a conceitos, ainda que, em alguns casos, a ênfase seja mais no aspecto categorial que sensorial do fenômeno (VIVEIROS DE CASTRO, 2011: 350-51).

Sendo assim, os animais se veem como pessoas, eles são gente. A condição originária de todos os seres era de ser gente, havendo, portanto, uma compreensão de que todos os elementos carregam a possibilidade de ser gente.

O aprofundamento da ideia desenvolvida anteriormente, a concepção dos animais vendo a si mesmos como pessoas, oferece abertura para a reflexão sobre a forma como cada espécie se manifesta. Isto é, torna-se possível dizer que cada espécie apresenta uma "roupa", uma forma externa que envolve e esconde a forma interna humana, que está visível somente para aqueles que são seus iguais, 
membros da mesma espécie, ou para os xamãs, já que estes são seres transespecíficos. Os xamãs, dentro do perspectivismo ameríndio, estabelecem a conexão entre as dimensões cosmológicas da prática indígena, por cruzarem as barreiras corporais e fazerem a ponte entre as subjetividades e os humanos.

Vendo os seres não-humanos como estes se veem (como humanos), os xamãs são capazes de assumir o papel de interlocutores ativos no diálogo transespecífico; sobretudo, eles são capazes de voltar para contar a história, algo que os leigos dificilmente podem fazer. $\mathrm{O}$ encontro ou intercâmbio de perspectivas é um processo perigoso, e uma arte política - uma diplomacia (VIVEIROS DE CASTRO, 2011: 358).

É possível falar, portanto, em uma unicidade de espírito, que seria a humana, que é comum a todos os seres animados. A pluralidade estaria relacionada apenas à aparência corporal, passível de variações, de acordo com as características de cada espécie, como algo que é possível trocar ou descartar. Este mundo, portanto, é altamente transformacional, permitindo que os seres troquem essas "roupas", passando pelas metamorfoses de espíritos que podem assumir as formas animais, ou mesmo o contrário, humanos que podem se transformar em animais.

Essa forma interna é o espírito do animal: uma intencionalidade ou subjetividade formalmente idêntica à consciência humana, materializável, digamos assim, em um esquema corporal humano oculto sob a máscara animal (VIVEIROS DE CASTRO, 2011: 351).

Viveiros de Castro (2011: 377-79) questiona se essa cosmologia dos múltiplos pontos de vista não implicaria que cada perspectiva é igualmente válida e verdadeira, e se não existiria uma representação de mundo correta e verdadeira. Para responder tal questão e não pender para o relativismo, o antropólogo considera as etnografias, observando que o que ocorre é o inverso: "todos os seres veem (“ representam”) o mundo da mesma maneira - o que muda é o mundo que eles veem" (2011: 378).

De fato, o antropólogo ressalta que, de acordo com a cosmovisão ameríndia, os animais impõem sobre o real as mesmas categorias e valores que os humanos usam, seus mundos giram em torno da caça e da pesca, da cozinha e das bebidas fermentadas, dos ritos de iniciação, dos xamãs, chefes e espíritos (2011:378-379). As cobras e as onças veem os humanos como tapires ou pecaris (pequenos mamíferos que servem como presa) sendo que os humanos também comem essas 
presas, consideradas como 'comida de gente'. Em virtude de sua humanidade pretérita, os não-humanos veem as coisas da mesma forma que os humanos - mas é importante destacar que as coisas que eles veem são diferentes: "o que para as almas dos mortos é um cadáver podre, para nós é mandioca pubando”, por exemplo. Assim, explica o antropólogo:

Se a lua, as cobras e as onças veem os humanos como antas ou porcos selvagens, é porque, como nós, elas comem antas e porcos selvagens, comida própria de gente. Só poderia ser assim, pois, sendo gente em seu próprio departamento, os nãohumanos veem as coisas como "a gente" vê. Mas as coisas que eles veem são outras: o que para nós é sangue, para o jaguar é cauim; o que para as almas dos mortos é um cadáver podre, para nós é mandioca pubando; o que vemos como um barreiro lamacento, para as antas é uma grande casa cerimonial... (VIVEIROS DE CASTRO, 2011: 379).

Contra a interpretação relativista do também antropólogo Gerald Weiss, que descreve o mundo dos Campa como "um mundo de aparências relativas, onde diferentes tipos de seres veem as mesmas coisas diferentemente' (1972: 170)", Viveiros de Castro argumenta que:

(...) isso é, em certo sentido, verdadeiro. Mas o que Weiss não consegue "ver" é que o fato de diferentes tipos de seres verem as mesmas coisas diferentemente é meramente uma consequência do fato de que diferentes tipos de seres veem coisas diferentes da mesma maneira. Pois o que conta como "as mesmas coisas"? Mesmas em relação a quem, a que espécie? O espectro da coisa-em-si ronda a formulação de Weiss (VIVEIROS DE CASTRO, 2011: 379).

O perspectivismo ameríndio proposto por Viveiros de Castro é, assim, um multinaturalismo, pois a perspectiva não é uma representação (2011: 379). Essa diferenciação se dá porque as representações são consideradas como propriedades do espírito, mas, para os índios, o ponto de vista está no corpo, depende da "roupa" que envolve determinado ser. A especificidade dos corpos é o que marca a diferença entre os pontos de vista, pois as sensações são sempre as mesmas, afinal, para a cosmovisão ameríndia, o humano está presente em todas as espécies, assim como nas cosmovisões ocidentais a animalidade é o traço que nos iguala às outras espécies:

Assim, se nossa antropologia popular vê a humanidade como erguida sobre alicerces animais,normalmente ocultos pela cultura - tendo outrora sido "completamente" animais, permanecemos "no fundo" animais - o pensamento indígena conclui ao contrário que, tendo outrora sido humanos, os animais e outros seres do cosmos continuam a ser humanos, mesmo que de modo não evidente. 
Em suma, para os ameríndios "o referencial comum a todos os seres da natureza não é o homem enquanto espécie, mas a humanidade enquanto condição" (Descola 1986: 120). Esta distinção entre a espécie e a condição humanas deve ser sublinhada. Ela tem uma conexão evidente com a ideia das roupas animais a esconder uma "essência" humano-espiritual comum, e com o problema do sentido geral do perspectivismo (VIVEIROS DE CASTRO, 2011: 356).

A morfologia dos corpos é essencial para determinar as diferenças de afecção; entretanto, o corpo não deve ser compreendido como algo fisiológico, ele diz respeito à forma ou ao conjunto de modos de ser que constituem um habitus. A perspectiva, portanto, tem origem no corpo - este enquanto feixe de afecções e capacidades (VIVEIROS DE CASTRO, 2011: 381; 387-97).

A diferença dos corpos, entretanto, só é apreensível de um ponto de vista exterior, para outrem, uma vez que, para si mesmo, cada tipo de ser tem a mesma forma (a forma genérica do humano): os corpos são o modo pelo qual a alteridade é apreendida como tal. Não vemos, em condições normais, os animais como gente, e reciprocamente, porque nossos corpos respectivos (e perspectivos) são diferentes. Assim, se a Cultura é a perspectiva reflexiva do agente objetivada no conceito de alma, pode-se dizer que a Natureza é o ponto de vista do agente sobre os outros corpos-afecções; por outras palavras, se a Cultura é a natureza do Sujeito, a Natureza é a forma do Outro enquanto corpo, isto é, enquanto algo para outrem. A cultura tem a forma do pronome-sujeito " $e u$ "; a natureza é a forma por excelência da "não-pessoa" ou do objeto, indicada pelo pronome impessoal "ele" (VIVEIROS DE CASTRO, 2011: 380-81).

Assim, é por meio do transformismo cosmológico proposto pelo perspectivismo ameríndio que se pensa a unidade cultural, em conjunto com a pluralidade de corpos. Souza (2014) ressalta que esta noção apresentada do multinaturalismo atribui um fundo originário de humanidade a todos os seres animados, sem, contudo, prender-se a uma visão animista, uma vez que o multinaturalismo não se resume à atribuição de caráter humano a todos os seres, ao mesmo tempo: "isto é, a onça, por exemplo, é gente, mas somente enquanto ela está no departamento das onças. Desse modo, quando a onça me vê, ela me vê como presa, assim como eu a vejo como predadora" (SOUZA, 2014: 2).

Para a devida compreensão dos pormenores relacionados às cosmovisões e mitologias ameríndias, é necessário estabelecer algumas observações acerca das particularidades dessas visões. Dentro das cosmovisões do perspectivismo ameríndio, as inversões de perspectivas não englobam a totalidade dos animais; sua ênfase se dá na relação binária entre presa e predador, jogando com as atribuições de papéis desempenhados pelos predadores (considerados como rivais dos humanos), e presas principais dos humanos; além disso, é necessário 
considerar a outra concepção acerca dos humanos, em sua condição como presas principais dos predadores.

Viveiros de Castro (2011) apresenta, também, uma noção de extrema importância para o pensamento ameríndio, a respeito da construção dos mitos, em que a constituição dos personagens mitológicos se dá sem a diferenciação entre humanos e animais, ou seja, possuem formas e comportamentos que variam entre os âmbitos humanos e animais, misturando-se sem delimitação concreta de sua constituição.

[O que é um mito?] - Se você perguntasse a um índio americano, é muito provável que ele respondesse: é uma história do tempo em que os homens e os animais ainda não se distinguiam. Esta definição me parece muito profunda (LéviStrauss \& Eribon 1988:193 apud VIVEIROS DE CASTRO, 2011: 354).

Nesse universo, há uma intercomunicabilidade. Na mitologia ameríndia não existe uma cisão entre o humano e o animal, tampouco há processos de diferenciação, uma vez que a condição comum aos humanos e animais apoia-se, como vimos, justamente sobre a humanidade, e não sobre sua animalidade. Os mitos narram a perda de atributos sofrida pelos animais que eram, na origem, humanos, demonstrando que a natureza se afasta da cultura, e não o contrário.

Essa noção da essência espiritual única, cuja roupagem externa varia de acordo com as espécies, está refletida, inclusive, na crença ameríndia praticada nas restrições alimentares, que considera alguns animais impróprios para a ingestão em razão de sua proximidade ao humano, o que traz a necessidade da dessubjetivação xamanística do animal - o xamã neutraliza seu espírito - para evitar uma retaliação. $\mathrm{O}$ espírito da presa, uma vez ingerida sem a neutralização, torna-se predador, por meio de uma inversão de perspectivas que é mortal ao humano, já que o transforma em animal. Essa passagem da mitologia ameríndia revela a conexão com a noção de "roupas animais" que escondem a essência espiritual comum aos seres.

Diante dos inúmeros problemas de tradução das cosmovisões ameríndias para a forma de vida ocidental, Viveiros de Castro (201) elenca um dos principais vícios do pensamento ocidental domesticado que corrobora com esse distanciamento: o objetivismo. Discutindo o ideal de Ciência que se tornou dominante em nossa sociedade, o antropólogo demonstra como tal ideal é guiado 
pelo valor da objetividade. Retorna-se à análise da compreensão do significado de conhecimento, bem como à sua efetivação. Isto é, o ato de conhecer alguma coisa implica em ter a capacidade de dessubjetivá-la plenamente. Conhece-se algo a partir do momento em que é possível vê-lo apenas de fora, considerando-o como um objeto.

Conhecer, para nós, é dessubjetivar tanto quanto possível. (...) Nossa ideologia básica é de que a Ciência será um dia capaz de descrever todo o real em uma linguagem integralmente objetiva, sem resto. Ou seja, para nós a boa interpretação do real é aquela em que se pode reduzir a intencionalidade do objeto a zero. Sabemos que as ciências sociais, na ideologia oficial, são ciências provisórias, precárias, de segunda classe. Toda ciência deve se mirar no espelho da física... O que significa isso? Significa guiar-se pela pressuposição de que quanto menos intencionalidade se atribui ao objeto, mais se o conhece (VIVEIROS DE CASTRO, 2011: 486-87).

A dessubjetivação para o conhecimento implica, igualmente, em desanimizar o sujeito estudado, ato exigido de maneira tão intensa que leva igualmente à desanimização daquele que conhece (ou objetiva um algo). Tal proposição afirmada pelo materialismo científico dominou as sociedades ocidentais, estabelecendo uma distinção radical em relação às cosmovisões ameríndias. Ainda que o materialismo científico em sua forma purista pense a antropologia como animista, quando esta considera os seres humanos como detentores de alma, ela ainda está distante do pensamento ameríndio, distanciando-se, inclusive, da maneira perspectivista como as sociedades ameríndias pensam o conhecimento.

De acordo com as epistemologias indígenas, o ato de conhecer algo está intrinsecamente relacionado à capacidade de atribuir o máximo grau de intencionalidade àquilo que se está conhecendo. Ao contrário da concepção ocidental, a boa interpretação e o conhecimento dos eventos se dão mediante a leitura da intencionalidade. A forma de vida ameríndia entende o aprofundamento do conhecimento por meio da aproximação com a subjetividade, ou seja, determinando o "objeto" de conhecimento como um sujeito.

"Sejamos objetivos." Sejamos objetivos? - Não! Sejamos subjetivos, diria um xamã, ou não vamos entender nada. O pecado epistemológico ali é a falta de subjetividade. Bem, esses respectivos ideais ou modelos implicam ganhos e perdas, cada um de seu lado. Há certos ganhos em subjetivar, como há perdas. Essas são escolhas culturais básicas (VIVEIROS DE CASTRO, 2011: 488). 
Esse entendimento a respeito do ato de conhecer permite a compreensão de como o Ocidente confina e "domestica" outras visões de conhecimento. A busca obsessiva pelo objetivismo considera a subjetividade e a animização como "pensamento selvagem", e tal pensamento seria pertinente apenas em espaços circunscritos e subalternos às ciências naturais. $\mathrm{O}$ ideal de subjetividade proposto pelas cosmovisões ameríndias, por exemplo, é aceito no mundo da arte - que engloba, consigo, as esferas da fantasia, do inconsciente, das emoções, e por isso não é ciência. Fora desse âmbito, a subjetividade não tem lugar: torna-se clandestina. O conhecimento científico, herdado do materialismo científico, impregnado do objetivismo, é tido como epistemologicamente superior a qualquer outro segmento que dê espaço para a subjetividade.

Voltando às nossas considerações a propósito relação da filosofia madura de Wittgenstein e o perspectivismo, nas Investigações, o filósofo considera a nomeação como um jogo primitivo da linguagem, existindo ainda outros jogos diversos. A concepção wittgensteiniana pensa a linguagem em seu pragmatismo, isto é, a linguagem não está restrita a uma forma lógica de proposição, ela não cabe em uma formalização. Os jogos de linguagem, portanto, em conjunto com suas regras, obedecem às semelhanças de família, mas sem que haja uma estrutura para dispor seus elementos. Os jogos de linguagem estão envolvidos com sua pluralidade e podem ser contemplados por meio das formas de vida, por meio de uma trama tecida pelas significações, o que nos leva a pensar que embora a visão wittgensteiniana sobre a linguagem não considere a subjetividade da mesma maneira que a cosmovisão ameríndia, ela se diferencia do objetivismo ao considerar as formas de vida como próprias de certa pessoa ou cultura, ao considerar os modos sui generis de pensamento, ao acolher - e não anular - a alteridade.

O que Viveiros de Castro (2011: 489) denomina "epistemologia xamânica" ilustra como as formas de vida ameríndias atribuem subjetividade às coisas:

Uma escultura talvez seja a metáfora material mais evidente desse processo de subjetivação do objeto. O que o xamã faz é um pouco isso: ele esculpe sujeitos nas pedras, paus e bichos, ele esculpe conceitualmente uma forma humana.

Salienta-se que, na cosmovisão ameríndia, o xamanismo é equivalente à ciência no ambiente ocidental. O xamã, em equiparação às concepções de Ciência, corresponde ao cientista; "o chocalho do xamã é o acelerador de partículas" 
(VIVEIROS DE CASTRO, 2011: 490). Essa passagem é essencial para a compreensão das dificuldades de tradução da tradição ameríndia para a ocidental: para o entendimento das sociedades não ocidentais, as relações funcionais internas devem ser preservadas.

A aproximação entre os pressupostos filosóficos wittgensteinianos e os escritos etnofilosóficos de Viveiros de Castro torna-se possível, principalmente, a partir da crítica incisiva à dicotomização e binarismo conceitual em que as sociedades ocidentais se fundamentam. A filosofia de Wittgenstein se afasta a tal ponto dos esquemas teóricos binaristas e conclusivos, que em suas anotações o filósofo afirma ter resumido sua atitude para com a filosofia quando disse: "a filosofia deveria apenas escrever-se como uma forma de composição poética" (VB, p. 43-4).

Ao analisar as sociedades não ocidentais, Viveiros de Castro narra sua experiência de pesquisa no sistema social encontrado nas comunidades indígenas do Xingu; em especial, evidencia uma dificuldade em descrever essa forma social cujo esqueleto institucional não se apoia sobre quaisquer dispositivos dualistas. Esse novo contato expôs as falhas da imagem básica antropológica que compreendia as sociedades indígenas como sociedades com metades, isto é, pensava-se a interpretação do sistema de pensamento e ação indígenas por meio das interpretações binárias.

Ficou claro para mim que o que acontecia no Xingu não podia ser reduzido à oposição entre o físico e o moral, o natural e o cultural, o orgânico e o sociológico. Ao contrário, havia uma espécie de interação entre essas dimensões muito mais complexa do que os nossos dualismos (VIVEIROS DE CASTRO, 2011: 477).

A partir da referida passagem do antropólogo, é possível realizar uma reflexão sobre sua ligação com as reflexões de Martins (2012), quando esta aproxima as cenas ameríndias à tradução, destacando que a produção antropológica de Viveiros de Castro não pode ser "traduzida" para a noção ocidental, pois a forma de vida ameríndia é ricamente composta por uma língua que, ainda que estranha, propõe um processo de cisão em relação às dicotomias tradicionais já tão arraigadas no imaginário dos sistemas sociais não ameríndios. Os binarismos ocidentais, vistos como opressores, não são capazes de abarcar as 
formas de vida ameríndias, logo, não traduzem as peculiaridades das cosmovisões não-ocidentais.

Martins (2012: 139), ao apresentar inicialmente uma compreensão do perspectivismo ameríndio, evoca uma passagem de Nietzsche em que este discute a origem do nosso conceito de "conhecimento": Essa explicação eu encontrei na rua; ouvi alguém do povo dizer: "Ele me
reconheceu" - então me perguntei: o que entende mesmo o povo por
"conhecimento"? O que quer ele, quando quer "conhecimento"? Não mais do que
isso: algo estranho deve ser remetido a algo conhecido. [...] nossa necessidade de
conhecer não é justamente essa necessidade do conhecido, a vontade em meio a
tudo o que é estranho, inabitual, duvidoso, descobrir algo que não mais nos
inquiete? Não seria o instinto do medo que nos faz conhecer? E o júbilo dos que
conhecem não seria precisamente o júbilo do sentimento de segurança
reconquistado? (NIETZSCHE, 2001: 250-251).

O perspectivismo nietzschiano, como vemos, recusa a noção de que conhecer seja reconhecer, isto é, reduzir o estranho ao que se julga conhecido. Da mesma forma também se deve evitar o impulso de "transpor para o (estranho) contexto ameríndio o (conhecido) pensamento perspectivista ocidental" (MARTINS, 2012: 140).

Por meio da análise dos rituais de reclusão pubertária do Alto Xingu, Viveiros de Castro nos permite observar que não existia uma diferenciação entre o corporal e o social, ambos haviam se fundido. Assim, essa sociedade indígena revelava-se como algo distinto das oposições familiares tradicionais entre cultura e natureza - termos que Viveiros de Castro (2011) entende como jargões tradicionais antropológicos, e por isso, tenta rompê-los -, e suas extensões, pensadas nas oposições binárias de interior e exterior, ego e inimigo, dentre outras. Ao refletir sobre as sociedades ameríndias, alheias às tradições de pensamento ocidentais, constata-se, por exemplo, que os elementos considerados como mentais ou abstratos, quando inseridos no contexto dessas organizações sociais, eram concretamente inscritos no corpo.

O contato com as sociedades indígenas também trouxe para Viveiros de Castro a possibilidade de visualizar uma paisagem panamericana, não mais somente amazônica, de que as sociedades ameríndias tratavam o tema mítico da distinção entre humanos e não-humanos de forma diferenciada da noção evolucionista ocidental, considerando a proposição da mitologia ameríndia de que os animais originariamente eram humanos, e depois deixaram de sê-lo, e em razão 
dessa ordem, a humanidade é vista como o elo em comum entre humanos e animais, como vimos.

Para a compreensão das proposições indicadas pelo perspectivismo ameríndio, é fundamental a discussão de um episódio narrado por Viveiros de Castro, em entrevista publicada originalmente na revista Sexta-feira, número 4, em 1999, posteriormente transcrita no final da obra A inconstância da alma selvagem (2011) que reúne vários ensaios do antropólogo. Viveiros de Castro conta que, por volta de 1996, o filho do líder dos Kayapó Mentuktire, chamado Raoni, morreu, quando estava sob os cuidados da aldeia dos Kamayurá do Alto Xingu. Raoni havia sido enviado pela família para realizar um tratamento xamanístico pelos membros Kamayurá. Durante uma crise epiléptica (epilepsia, por sua vez, diagnosticada por médicos brancos), o rapaz havia matado dois índios, e pouco tempo depois, também faleceu. A morte de Raoni trouxe um clima de tensão intergrupal e sua tribo, os Kayapó Mentuktire, acusavam os Kamayurá de feitiçaria. Megaron, mentuktire e sobrinho uterino de Raoni, então diretor do Parque do Xingu, veio em defesa do rapaz falecido, dizendo que os Kamayurá eram, de fato, feiticeiros:

Pois bem. Megaron argumentava, em sua carta: "Esse rapaz morreu porque foi enfeitiçado pelos Kamayurá. É verdade que ele matou duas pessoas antes de morrer, mas isso foi porque ele achou que estava matando animais, pois os pajés kamayurá deram um cigarro para ele e ele achou que estava matando bicho. Quando voltou a si, viu que eles eram humanos e ficou muito abalado". Essa é a explicação que recorre ao argumento perspectivista, esse negócio de ver gente como animal (VIVEIROS DE CASTRO, 2011: 482-83).

A explicação utilizada por Megaron, como aponta Viveiros de Castro, implica diretamente no uso do argumento perspectivista, pois estabelece que, quando uma pessoa vê outros seres humanos como não humanos, ela mesma deixou de ser humana, ou seja, ela está doente, "tornando-se outra". Megaron aponta que os xamãs kamayurá enfeitiçaram Raoni, tirando-lhe a humanidade e fazendo com que visse os humanos como animais. Ainda além, essa desumanização do rapaz fez com que ele se comportasse tal qual um animal, sugerindo, nesse ponto, a tese perspectivista de que os animais não nos veem como humanos, e sim como animais. Ao mesmo tempo, os animais não se veem como animais. Por baixo das "roupas" externas que protegem e ocultam sua 
entidade espiritual, os animais veem uns aos outros da mesma forma que os humanos se veem, ou seja, os animais se veem como humanos.

O pensamento ocidental, então, ao desenvolver as imagens mitológicas modernas encontra-se "nas antípodas" da mitologia ameríndia. Para esta última cosmovisão, a origem diverge da teoria evolucionista de Darwin de que os humanos são animais que conquistaram algo, como alma, cultura, linguagem, regras (por extensão, espírito), etc. Para os povos ameríndios, os animais consistem em humanos que perderam algo; logo, a humanidade é a forma geral do ser, é um pressuposto radical, ela é o fundo universal do cosmos (VIVEIROS DE CASTRO, 2011: 374).

Quando o observador se depara com uma afirmação etnográfica de que alguma tribo indígena afirma que "onças são gente", é necessário ter em mente que tal afirmação não é uma análise simples, ou trivial. As onças são gente, mas são também onças. Elas são animais, mas possuem um lado oculto que ainda se caracteriza como humano. Propor que "onças são gente" difere-se da proposição de que "piranhas são peixes", pois nessa frase, não há a intenção de transparecer que as piranhas tenham um lado oculto que é peixe. É possível destacar, novamente, o encontro do argumento perspectivista com a fala do antropólogo, em especial, quando este afirma que as onças são gente porque a oncidade é uma potencialidade das gentes, ao mesmo tempo em que é particular da gente humana. É essencial observar que não há lugar para o estranhamento nessa fala de que “animais são gente”, já que em vários contextos sociais da cultura ocidental ocorre a proposição contrária, quando se afirma que "os seres humanos são animais" (2011: 484).

É pertinente observar, também, a maneira como o perspectivismo ameríndio distancia-se do relativismo, e como seria incorreta tal aproximação. Para Viveiros de Castro (2008), há apenas uma hipótese em que o perspectivismo seria um relativismo:

[...] se os índios dissessem que para os porcos todas as outras espécies são no fundo porcos, embora pareçam humanos, onças, jacarés etc. Não é isso que os índios estão dizendo. Eles dizem que os porcos no fundo são humanos; os porcos não acham que os humanos sejamos no fundo porcos (VIVEIROS DE CASTRO, 2011: 485). 
Retomando a proposição de Descola (2011: 361), de que o ponto de vista humano é o referencial, Viveiros de Castro reafirma a posição de que todos os seres - animais, espécies, sujeitos - que estiverem ocupando o local cujo ponto de vista é referencial verão a si próprios como humanos, verão sua humanidade, da mesma maneira que nós humanos nos vemos em nossa humanidade.

Ainda que nós, humanos, nos vejamos como humanos (como fazem todas as espécies em relação aos seus), não existem garantias de que a maneira como vemos a nós mesmos seja o modo verdadeiro de ver, afinal, todos os seres vivos se veem dessa maneira. Mas essa proposição também revela que se outras espécies não nos veem como nós nos vemos, já que somos incapazes de vê-las como elas se veem, elas são igualmente incapazes de assim se verem.

A história narrada por Viveiros de Castro sobre Megaron permite a aproximação do argumento perspectivista ameríndio em outro exemplo: para os indígenas, uma verdadeira onça não ataca os homens - pois verdadeiramente perigoso, no mundo, é apenas o homem. Se uma onça ataca um homem, isso significa, de imediato, que ela não é uma onça comum, mas, sim, um homem disfarçado de onça, quando ela vivencia um "momento" de homem: apenas os homens matam os homens.

É importante salientar o esclarecimento de que os índios não dizem que cada espécie vê as coisas de uma maneira diferente; na verdade, como se disse, eles dizem o contrário: cada espécie vê as coisas exatamente da mesma maneira, o que muda são as coisas. Não existem várias maneiras de ver, há apenas uma, pois o que varia é o próprio mundo, e não a forma de vê-lo. (VIVEIROS DE CASTRO, 2011: 373).

Partindo do pressuposto de Viveiros de Castro de que cada uma das espécies de seres vê a si mesma e às demais espécies de forma singular, ao ver a si mesma como humana, e ver todas as outras como não humanas, Martins (2012) mergulha nos relatos etnográficos para, dessa maneira, aproximar-se da forma de vida do mundo ameríndio, valendo-se da proposição wittgensteiniana, de que imaginar uma língua é imaginar uma forma de vida. O contato com o perspectivismo ameríndio permite a aproximação com essa singular forma de vida, que pensa o "sangue", em sua concepção humana, como a "cerveja do jaguar". Já que cada espécie se vê como a constituição autêntica da humanidade, a onça, quando lambe o sangue de sua presa abatida, se vê como gente bebendo cauim. Ao mesmo 
tempo, por outro lado, já que nos vê como não humanos, a onça nos vê como presa.

As cosmovisões ameríndias ou, aproximando-nos de Wittgenstein, as formas de vida ameríndias assumem que os animais fazem uso das mesmas categorias e valores humanos, principalmente quando se considera que a existência dos animais é fundamentada e enraizada em alguns rituais sociais como a caça, o casamento, a pesca, a guerra, em torno dos quais gravitamos também nossa existência.

Para o perspectivismo ameríndio, não existem pontos de vista sobre as coisas, uma vez que as coisas e os seres é que constituem pontos de vista, como se viu. Nessa perspectiva peculiar, o ponto chave não é entender como os animais veem o mundo, por exemplo, mas de que mundo eles são ponto de vista (VIVEIROS DE CASTRO, 2011). Os pontos de vista, nesse contexto, não dizem respeito às emanações de um self fixo, como salienta Martins (2012: 144):

[...] se esses índios não supõem um único mundo, tampouco vivem uma unidade do self. Pois simplesmente não compareceria a expectativa de um self ou sujeito que fosse a "condição originária e fixa de onde emana o ponto de vista". Desconvida-se aqui, quer pensemos em objetos ou sujeitos, não apenas a percepção substantiva do ser, mas também sua percepção intransitiva - ao que tudo indica, entre os índios, ser é sempre ser-para, ser-com.

Martins (2012) nos descreve, em certa medida, como reféns de uma metafísica do ser como substância intransitiva, ao delimitar a dificuldade da tradução da forma de vida ameríndia para a compreensão em uma língua familiar ocidental. Tomamos a frase "o sangue é a cerveja do jaguar" da mesma forma que a proposição "Julieta é o sol”, enquanto metáforas que indicam que Julieta não é o sol, mas é como se fosse (e que o sangue não é a cerveja, mas é como se fosse); essa expressão "como se" desloca radicalmente a própria experiência de tradução entre nós e os indígenas.

Neste momento, parece insinuar-se uma diferença em termos do que se disse sobre o entendimento nietzschiano: para ele, nós "acreditamos possuir algum saber sobre as coisas propriamente, quando falamos de árvore, cores, neve, flores, mas não temos entretanto aí mais do que metáforas das coisas, as quais não correspondem" (NIETZSCHE, [1873] 2001: 11).

Ao refletir sobre as partições forjadas na linguagem, quando esta é vista como práxis histórica, descontínua e não universal, compreendem-se as 
identidades como criaturas da linguagem, o que contribui para a constituição da identidade da própria linguagem. Essa reflexão de Martins (2012) proporciona um elo entre a filosofia wittgensteiniana e a proposição etnofilosófica de Viveiros de Castro, pois, partindo do princípio que imaginar uma língua é imaginar uma forma de vida, é necessário, da mesma forma, admitir a possibilidade de que formas de vida distintas, ou diferentes cosmovisões, sejam capazes de imaginar de formas distintas o que seja uma língua. Portanto, a mesma noção se estende para o que seja aprender uma língua, ensiná-la, compreendê-la e, principalmente, traduzi-la.

\section{3}

\section{Um perspectivismo wittgensteiniano? Uma aproximação entre Deleuze e Wittgenstein: a leitura de Prado Jr.}

No ensaio "Plano de imanência e vida", Prado Jr. aponta que há uma inegável pluralidade epistemológica abrigada nos escritos da maturidade de Wittgenstein e por este viés, pode-se aproximar o pensamento wittgensteiniano do pensamento de Deleuze, filósofo que preconiza para a filosofia uma tarefa de criar conceitos que "são como as vagas múltiplas que se erguem e que se abaixam, mas o plano de imanência é a vaga única que os enrola e desenrola". Numa primeira visada, tal aproximação aparece como algo incompatível com as afirmações de Wittgenstein, sobretudo a que propõe, em oposição ao que diz Deleuze, um lugar modesto para a filosofia já que ela não muda nada

A filosofia não deve, de modo algum, tocar no uso efetivo da linguagem; em último caso, pode apenas descrevê-lo.

Pois também não pode fundamentá-lo.

A filosofia deixa tudo como está (PU, §124).

Justificando a confessadamente inesperada aproximação entre os filósofos, Prado Jr. transcria a linguagem singular de Deleuze e Guattari nas seguintes palavras:

O plano de imanência é, entre outras coisas, uma espécie de solo intuitivo, cujos "movimentos infinitos" são fixados pelas "coordenadas" construídas pelo movimento finito do conceito. O plano de imanência, despovoado de conceito, é cego (no limite, é puro Caos); o conceito, extraído de seu "elemento" intuitivo (no sentido de atmosfera), é vazio. (Prado Jr, 2004: 143). 
O leitor atento de Wittgenstein, acostumado à irredutibilidade dos jogos de linguagem e à multiplicidade das formas de vida, já encontrou aí alguma afinidade de pensamentos. Se a tarefa filosófica que interessa a Deleuze pretende, por um lado, criar, não entende, por outro lado, que essa atividade possa fixar ou apaziguar a inquietação própria ao pensamento, numa palavra, à vida, que se desenrola nos movimentos das "vagas múltiplas". Deleuze insiste também na ideia da filosofia como um construtivismo (DELEUZE e GUATTARI, 2005: 51), privilegiando, nessa noção, uma cumplicidade com o intuicionismo recebido da tradição francesa encontrada, por exemplo, em Poincaré que enfatiza "mais a criação da teoria do que sua exposição lógica e axiomática" (PRADO Jr., 2004: 141). Ou seja, o construtivismo aí reivindicado explicita a ideia de que "não há conceito em si, ele é o resultado de um trabalho sobre uma matéria" (PRADO Jr., 2004: 141). Vimos, nas discussões anteriores, que Wittgenstein critica a empresa de Moore ao tentar dar fundamento ao que não tem fundamento, ou melhor, ao que tem como único fundamento possível aquilo encontrado na própria vida, nas coisas que são como são, o que também remete ao construtivismo reinvindicado por Deleuze, já que esses conceitos são "acontecimentos" na superfície do puro caos. Assim, o plano de imanência sem os conceitos é "cego", motivo pelo qual não se trata, ao cortar o caos, de conhecer, mas de pensar (PRADO Jr., 2004: 144). Voltamos, assim, à nossa comparação com a obra madura de Wittgenstein, sobretudo Da certeza que, ao modo do filósofo, em sua "discreta poesia" ${ }^{20}$, instiga o pensamento a ir contra um dogmatismo quando tratamos de conhecimento, pensamento, filosofia, cabendo ao filósofo nada além do que uma atividade calcada numa visão perspícua e sinóptica que "atravessa a todos os jogos de linguagem e que não privilegia nenhum” (PRADO Jr., 2004: 55, grifo nosso), dando à filosofia, por conseguinte, um inegável caráter antidogmático, aproximado ao vislumbre do infinito de Nietzsche (tão caro a Deleuze), como requer a visão que tudo põe em perspectiva. Encontro de orientações de pensamentos e desencontro de expressão? Provavelmente.

Mas é Wittgenstein mesmo quem adverte que é difícil a ideia da Grundlösigkeit ${ }^{21}$ do fundamento, onde "a pá entorta” (PU, § 217). Motivo pelo

\footnotetext{
${ }^{20}$ Ver em MARTINS (2011): A escrita poética de Wittgenstein, sua tradução.

${ }^{21}$ Grundlösigkeit (al.): improcedência, falta de base.
} 
qual o filósofo sinaliza o perigo de se falar de um homem racional, que pelo exercício de sua Razão terminaria por atingir "um” jogo de linguagem mais aparentado com "a" verdade. O que se atinge pela razão é um lugar de caos (PRADO Jr., 2004: 29). Prado Jr. argumenta existir em Deleuze a mesma advertência contra a ilusão que, no fundo, remete a um ego da razão, aconselhando, como Wittgenstein, no lugar de um Ich denke (Eu penso) um Es denkt (Isso pensa):

Vislumbrando, embora obscuramente, o plano de imanência, a fenomenologia perdeu-o de vista desde o início, fazendo dele um campo ego-centrado e introduzindo em seu próprio coração o transcendente na forma de comunicação ou da intersubjetividade. No coração mesmo do plano de imanência, o universal da comunicação abre uma brecha por onde a imanência se esvai numa hemorragia incontrolável, vertendo no transcendente, do qual o plano se torna mero predicado - reiterando o processo de confisco ou sequestro operado no passado pelos universais da contemplação (Platão) e da reflexão (Kant) (PRADO Jr., 2004: 145).

Assim, a multiplicidade característica ao perspectivismo presente em Wittgenstein e Deleuze, pode ser vista, antes de qualquer coisa, por meio da ideia de jogos de linguagem, em uma aproximação entre as duas produções.

Retornando ao tão comentado $\$ 559$ de Da Certeza, Wittgenstein propõe que:

Você deve ter em atenção que o jogo de linguagem é, por assim dizer, imprevisível. Quero dizer: não se baseia em fundamentos. Não é razoável (ou irrazoável).

Está aí - tal como a nossa vida. (UG §559).

$\mathrm{Na}$ análise da referida passagem wittgensteiniana, Prado Jr. atenta para a ligação desta com o título e o conteúdo do último escrito de Deleuze (L'immanence: une vie...), ressaltando que os conceitos em geral e a ideia de racionalidade em particular assumem sentido na filosofia wittgensteiniana apenas no interior de um jogo de linguagem. Na continuidade, o autor compreende que o jogo de linguagem não é somente contingente como uma vida, mas, sim, a expressão dessa vida, ou seu desdobramento, que na sua dimensão simbólica e prática, consiste em uma dobra que se redobra e se enrola sobre si mesma. A metáfora deleuziana da "dobra" é utilizada por PRADO Jr. para iluminar a articulação entre práxis e simbolismo nos escritos do Wittgenstein maduro, escritos que nos falam de uma forma de vida capaz de enrolar-se sobre si mesma, inserida nas regras dos jogos de linguagem. 
Chega-se, então, à questão da multiplicidade dos jogos de linguagem, onde se permite a discussão do perspectivismo filosófico. Para Prado Jr. (2004: 161), como já vimos, esse perspectivismo estaria desprovido de relativismo, o que implica, imediatamente, um retorno às proposições de Nietzsche, e também às de Deleuze, ao discutir a questão de qual seria o melhor plano de imanência. A definição deleuzeana do plano de imanência é colocada como um horizonte peculiar:

[...] mas o plano é o horizonte dos acontecimentos [...] não o horizonte relativo que funciona como um limite, muda com um observador e engloba estados de coisas observáveis, mas o horizonte absoluto, independente de todo observador, e que torna o acontecimento como conceito independente de um estado de coisas visível em que ele se efetuaria (DELEUZE; GUATTARI, 1992: 52).

Prado Jr. ressalta em Wittgenstein, desde o Tractatus, a articulação entre o lógico e o empírico:

Retornemos à questão da possível articulação entre o empírico e o transcendental fora do esquema "ternário" da filosofia kantiana. Aqui, novamente, reencontramos Wittgenstein que leva ao máximo a aproximação entre o empírico e o transcendental, que também inclui o conceito de "vida" no léxico do transcendental, desde o Tractatus até seus últimos escritos, quaisquer que tenham sido as transformações de seu pensamento ao longo do tempo (PRADO Jr., 2004: 166).

Assim, o esforço de alcançar as articulações entre filosofia e vida parece ser um caminho de aproximação entre os dois pensadores, pois para o Wittgenstein maduro está claro que a significação só emerge no fluxo da vida, na ação que se desenrola no tempo: tanto as regras quanto os critérios, que possibilitam conferir significado à linguagem, têm um inegável caráter público, sendo, como vimos, até mesmo a "linguagem privada" uma ilusão. Para Deleuze, igualmente,

A filosofia só tem sentido quando provocada pela vida ou pelo mundo. Lembremos a célebre frase de Diferença e repetição: "Há algo, no mundo, que força a pensar". Essa espécie de violência exige, como resposta, uma "clínica de si mesmo". Eis o aspecto ético sublinhado por Foucault, que faz a filosofia aproximar-se mais da poiesis e da ars que da pura teoria. Seguindo a crítica bergsoniana da metafísica clássica, a filosofia, também aqui, é a dissolução de falsos problemas, invenção de problemas que dão o que pensar e proliferação de paradoxos (PRADO Jr., 2004: 169).

Lembremos ainda uma vez que também Wittgenstein reconhece a filosofia como produção, arte poética que se recusa à fixação de qualquer teoria. Para 
Deleuze, os conceitos filosóficos consistem em totalidades fragmentárias que não se ajustam umas às outras, uma vez que suas bordas não coincidem (DELEUZE e GUATTARI, 1992: 51). Ao pensar os conceitos, os autores propõem que estes não compõem um quebra-cabeça.

E, todavia, eles ressoam, e a filosofia que os cria apresenta sempre um Todo poderoso, não fragmentado, mesmo se permanece aberto: Uno-Todo ilimitado, Omnitudo que os compreende a todos num só e mesmo plano. (...) Os conceitos e o plano são estritamente correlativos, mas nem por isso devem ser confundidos. O plano de imanência não é um conceito, nem o conceito de todos os conceitos. Se estes fossem confundíveis, nada impediria os conceitos de se unificarem, ou de tornarem-se universais e de perderem sua singularidade, mas também nada impediria o plano de perder sua abertura. A filosofia é um construtivismo, e o construtivismo tem dois aspectos complementares, que diferem em natureza: criar conceitos e traçar um plano (DELEUZE \& GUATTARI, 1992: 51).

Apesar de a filosofia segundo Deleuze apresentar um Todo Poderoso, que consiste em um plano de imanência dos conceitos, denominado planômeno, é preciso atentar para o fato de que não podem ser confundidos, pois o plano de imanência, como se disse, não é um conceito. Na passagem já citada, temos:

Os conceitos são como as vagas múltiplas que se erguem e que se abaixam, mas o plano de imanência é a vaga única que os enrola e os desenrola. O plano envolve movimentos infinitos que o percorrem e retornam, mas os conceitos são velocidades infinitas de movimentos finitos, que percorrem cada vez somente seus próprios componentes (DELEUZE; GUATTARI, 1992: 51).

Conceito e plano são coetâneos, portanto, já que um não se instaura sem o outro (Prado Jr., 2004: 151). Mas é preciso ainda compreender a conexão entre o plano e o caos na filosofia deleuziana, o que Prado Jr. faz recorrendo à distinção entre filosofia e ciência encontrada em Deleuze e Guattari (1992): ambas mergulham no caos; uma, a ciência, procura dar-lhe referência, mas para isso abre mão dos movimentos e velocidades infinitos, operando, desde o início com uma desaceleração da velocidade para a fixação de estados-de-coisas. Já a outra, a filosofia, faz a proeza de mergulhar no caos sem nada perder do infinito ou do Devir, isto é, "instala-se a oposição entre uso não referencial e uso referencial da linguagem, entre a autoposição do conceito e a função proposicional ligada essencialmente a seus valores de verdade" (PRADO Jr., 2004: 151). Em Wittgenstein, da mesma forma, a experiência de mergulho no caos é justamente a possibilidade de nele se encontrar, não estando, no entanto, amparado por um sistema de regras (a linguagem). É o fora e anterior à linguagem, a in-fância de 
que trata Agamben, aquele estado único em que pode ocorrer toda experiência genuína, pois de outra forma já nos encontramos num contexto de "certeza" que impede a experiência. A condição necessária da experiência é a cegueira para as regras, ou, nos dizeres de Prado Jr., na cumplicidade entre pensamento e loucura.

Precisamente porque o plano de imanência é pré-filosófico, e já não opera com conceitos, ele implica uma espécie de experimentação tateante, e seu traçado recorre a meios pouco confessáveis, pouco racionais e razoáveis. São meios da ordem do sonho, dos processos patológicos, das experiências esotéricas, da embriaguez ou do excesso (DELEUZE \& GUATTARI, 2005: 58).

Assim, o plano de imanência (que quando relacionado ao caos é sempre plural, planos, como os jogos) pode ser relacionado às pseudoproposições de base $^{22}$, que nada mais são do que o "alicerce que ignora a partilha entre o verdadeiro e o falso" (PRADO Jr., 2004: 156). A distinção entre Weltbild e Weltanschauung será necessária para mostrar o alcance do paralelo proposto por Prado Jr.. Enquanto um Weltbild é "um amálgama de pseudoproposições cristalizado na base de um jogo de linguagem”, uma Weltanschauung é a ilusão instaurada quando se toma esse amálgama como visão fundante, isto é, pretendêla fundante de algum conhecimento. Tanto Deleuze quanto Wittgenstein fazem, portanto, uma denúncia de "algo como um pecado mortal e original, inscrito no próprio coração da tradição da filosofia, e o que se anuncia é uma nova via que permita redimi-lo, sem abandonar a filosofia” (PRADO Jr., 2004:158). Em outras palavras:

Fazendo cruzar os dois diagnósticos e recorrendo às linguagens diferentes dos dois filósofos (por detrás das mesmas metáforas, um mesmo diagnóstico?) podemos dizer que o pecado da filosofia (que a degrada em Weltanschauung) é compreender-se como teoria ou representação e entender o Weltbild, ou o plano de imanência, como um conjunto de proposições que se referem a objetos ou estadosde-coisas transcendentes, no regime da Übereinstimmung ou da adequatio, e não como um "fazer", ou como uma prática construtiva que introduz, no caos, um mínimo de consistência e que exprime a forma imanente de "uma vida". [...] é a própria ideia de racionalidade que se encontra subordinada a uma espécie de

\footnotetext{
${ }^{22}$ Para o empirismo clássico, apenas as ideias e os conceitos provenientes das impressões sensíveis possuem significado. É nessa ideia que se dá a partilha entre o verdadeiro e o falso. No Tractatus, Wittgenstein se ocupou sobre como as proposições são capazes de representar estados de coisas. À ciência, por exemplo, apenas interessam as proposições logicamente significativas. Essas se distinguem das proposições da filosofia, isto é, das pseudoproposiçoes (TLP 1.1, 2.18, 4.021 e PU $\S \S 90$ a 119). Tal distinção, para Wittgenstein, demarca os limites entre ciência e filosofia: enquanto uma (ciência) dá lugar ao uso referencial da linguagem, ou seja, à fixação de estados-decoisas, outra (filosofia) dá consistência ao caos sem nada perder do infinito ou do Devir (PRADO Jr., 2004: 153).
} 
"princípio da razão contingente", como já se falou a propósito da filosofia de Deleuze (PRADO Jr., 2004: 158, 59).

Assim, esboça-se um perspectivismo filosófico (que imediatamente nos remete a Nietzsche, como vimos) no entrecruzamento entre a ideia de um construtivismo subjacente à concepção wittgensteiniana da linguagem e do conhecimento e a do caos que transparece na ideia de um "mundo" anterior às regras (PRADO Jr., 2004: 161). O perspectivismo sem relativismo já anteriormente reivindicado para o pensamento wittgensteiniano por Luiz Henrique Lopes dos $\operatorname{Santos}^{23}$, precisa, no entanto, ser conciliado com a proibição a todo e qualquer juízo de valor, mas isso parece ser difícil fazer, sobretudo se levarmos em conta o desprezo que Wittgensteien declara sentir pela forma de vida tecnocientífico-industrial, chamada por ele "decadente". Para desfazer o aparente paradoxo, Prado Jr. vai recorrer aqui a um pensamento de Wittgenstein que aparece na obra Cultura e valor:

O gênio se distingue do homem reto, não porque tem mais luz, mas porque concentra essa luz, graças a uma espécie de pequena lente, num ponto ardente" (VB, p. 59).

A analogia que vale para os indivíduos é a mesma para as formas de vida: uma não é melhor que a outra, distinguem-se não pela "quantidade de força e de autenticidade", mas pelo modo como dispersam ou concentram essa força. Wittgenstein declara sua preferência pela forma de vida que "não proíbe que nos lancemos insensatamente - sabendo-o - contra os limites da linguagem, abrindo o espaço da ética, da arte e da religião" (PRADO Jr., 2004: 162).

A lógica, ensina-nos o leitor atentíssimo de Wittgenstein, uma vez submissa a uma estabilidade do significado, entra em desarmonia com o devir, com o fluxo requerido pela vida (e pela arte). Perceber esse "sintoma" levou Wittgenstein dela (lógica) para a gramática, "declarando guerra a todo tipo de fundacionalismo, num espírito ao mesmo tempo anarcôntico e nomádico" (PRADO Jr., 2004: 169):

(...) evitemos a todo custo transcender o plano de imanência. Deslisemos sobre sua superfície, nada o transcende, nihil absconditum, seja céu, seja inferno. Pensar não é determinar objetos - esta tarefa, que transforma o plano de imanência em sistemas de estados de coisas, cabe à ciência. Pensar é jogar-se contra os limites da

\footnotetext{
${ }^{23}$ Cf. o ensaio de Luiz Henrique Lopes dos Santos, "A essência da proposição e a essência do mundo", na apresentação de sua tradução ao Tractatus Logico-Philosophicus de Wittgenstein, Edusp, 1993.
} 
representação e subvertê-la. Se me permitirem a insistência, pensar é liberar o fluxo da vida e expandir sua esfera. (PRADO Jr., 2004: 170)

Recorrendo ainda ao pensamento de Luiz Henrique Lopes dos Santos, em entrevista concedida a Marcelo Carvalho (CORBELLI \& CARVALHO, 2013: 34) ele afirma que "as Investigações Filosóficas de Wittgenstein constituem um pensamento perspectivista”, pois tudo que se diz é dito a partir de uma perspectiva representativa, motivo pelo qual não tem sentido perguntar pela verdade dessa perspectiva porque "ou essa pergunta é feita da mesma perspectiva, e daí a sua resposta vai ser tautológica, ou ela é feita de outra perspectiva e, portanto, ela vai apenas testemunhar da diferença entre as perspectivas”. Concluir que há aí um relativismo é fazer uma leitura equivocada que tem o veto do próprio Wittgenstein no seu último escrito, Da certeza. Nas palavras de Luiz Henrique Lopes dos Santos:

se tudo que eu digo eu digo de uma perspectiva, uma mesma coisa só pode ser dita de uma perspectiva. Portanto, não faz sentido dizer que uma mesma coisa é verdadeira de uma perspectiva e falsa de outra, porque de outra perspectiva, não é mais a mesma coisa. Isto é, eu tenho um relativismo com respeito ao sentido das proposições: uma proposição ganha o seu sentido relativamente a uma perspectiva. No entanto eu não tenho um relativismo quanto à verdade. Porque, dada a proposição com sentido naquela perspectiva, se ela é verdadeira ou falsa independe agora da perspectiva. Dado o sentido da proposição, é o mundo que deve dizer se ela é verdadeira ou se ela é falsa (CORNELLI \& CARVALHO, 2013: 36).

Percebe-se, assim que essa filosofia se afasta radicalmente das dicotomias reducionistas; bem ao contrário, abre-se exemplarmente para a diversidade e infinidade de significação. Não por acaso, esse pensamento em sua fertilidade ganhou rapidamente outros campos como o da sociologia, o da antropologia, o dos estudos da linguagem, para citar só alguns. Ali onde se pretende exatidão, Wittgenstein convida às aporias.

$$
* * *
$$

Esta seção teve como objetivo discutir as noções sobre o perspectivismo filosófico, em específico, por meio da aproximação entre as produções dos filósofos Wittgenstein e Deleuze. Tivemos como apoio os comentários de Prado Jr. (2004) que em sua análise realizou uma associação entre o perspectivismo deleuzeano e as proposições wittgensteinianas. Para aprofundamento do perspectivismo na filosofia de Wittgenstein recorremos também aos comentários de Luiz Henrique Lopes dos Santos. 
Tanto na filosofia de Deleuze quanto na de Wittgenstein encontramos uma recusa de redução do horizonte do pensamento nas ideias de plano de imanência e jogos de linguagem que, como vimos, guardam alguma reciprocidade. Tais ideias, longe de aquietarem o pensamento, mostram, isso sim, a filosofia como produção ou construção, ligada, ao mesmo tempo, ao fluxo da vida, em diálogo constante com a não filosofia. Um e outro filósofo apontam assim para a necessidade de libertar a filosofia do caráter dogmático que a tradição se incumbiu de trazer para ela, devendo ser entendida, portanto, não como uma teoria em sua imobilidade, mas como atividade de interpretação e produção infinitas, de onde o caráter perspectivo encontrado em ambas, o que se revela também em suas capacidades de criticar as empresas filosóficas que buscam fixar universais, ou, como nas palavras de Luiz Henrique Lopes dos Santos no ensaio já lembrado aqui: “O que a filosofia quer dizer existe e importa apreendê-lo. Apenas não se pode apreendê-lo da maneira canhestra que prescreve a filosofia tradicional" (TLP, 2010: 101). 
Infância, alteridade, ensino e perspectiva em Wittgenstein

\author{
Estaria eu fazendo psicologia da \\ criança? Estou construindo uma conexão \\ entre o conceito de ensino e o conceito de \\ significado. (L. Wittgenstein) \\ É bem literalmente que é preciso compreender a fórmula de Godard: as crianças são \\ prisioneiros políticos. (G. Deleuze)
}

Do Tractatus aos escritos maduros de Wittgenstein, uma grande diferença se refere ao eu, que, de limite do mundo (o olho que tem diante de si o campo visual, mas que não está, ele mesmo, inserido no mundo), passa-se a um eu como expressão em atos, agindo no e com o mundo. Essa diferença aparece no diálogo estabelecido com a antropologia que dá ênfase aos laços entre os jogos de linguagem e as formas de vida. Parece pertinente pensar que os anos vividos no interior da Áustria lecionando para crianças tenham, de alguma maneira, contribuído para a manifestação do privilégio ao perspectivismo em detrimento do paradigma universalista em suas concepções sobre a linguagem, até porque seus escritos da maturidade revelam muitas cenas de ensino no cerne das discussões, dando corpo aos jogos de linguagem. Verifica-se, na obra da maturidade de Wittgenstein, sua recusa por uma teoria ao mesmo tempo em que convivem sem hierarquias os múltiplos jogos de linguagem, tornando possível imaginar diferentes formas de vida.

Para Bouveresse (1977), Observações sobre 'O Ramo de Ouro', de Wittgenstein, pode ser considerado um dos textos mais esclarecedores para a compreensão do espírito da filosofia wittgensteiniana e, igualmente, pode ser considerado "um documento importante para uma reflexão crítica sobre os métodos e os resultados da pesquisa sociológica e antropológica" (BOUVERESSE, 1977: 43), bem como constitui "uma reação violenta contra o etnocentrismo" (p. 45). Bouveresse vincula o pensamento wittgensteiniano a um combate incessante da tendência específica dos filósofos de tentarem se colocar fora de toda espécie de jogo, real ou imaginário, e assim, julgando estar fora, arriscarem-se a dizer o que apenas deve ser mostrado. Ainda pontua que "em certo sentido, ele (Wittgenstein) jamais renunciou à distinção que introduziu à época do Tractatus entre o que pode ser dito e o que apenas pode ser 
mostrado (no uso, na aplicação, na prática, etc.)" (BOUVERESSE, 1977: 52. grifo nosso.) Bouveresse observa aquilo que é bastante caro a este trabalho, a implicação do ensino para conduzir nossas certezas que, em Wittgenstein, revelam-se nada mais que crenças:

Wittgenstein observa, a respeito do famoso problema dos fundamentos da aritmética: "Ensinem-na, e então vocês a terão fundado" (Philosophische Grammatik, p. 297). Isso não significa evidentemente que tudo poderia ser ensinado, mas que tudo o que pode ser ensinado pode, de certa maneira, ser fundado. A ideia de superioridade de nossa cultura não é o resultado de uma simples comparação, mas de um ensinamento; ela é uma herança hoje contestada porque se tornou contestável e não porque seja desprovida de fundamento (como se a ideia de que possa existir um fundamento tivesse algum sentido) (BOUVERESSE, 1977: 53).

$\mathrm{Na}$ interpretação dos últimos escritos de Wittgenstein, é bastante frequente a tendência a apagar a tensão entre dizer/mostrar estabelecida pelo jovem Wittgenstein, garantindo em sua filosofia madura um "não lugar" para o indizível. Para aqueles que como Perloff, Cavell e, mais aguçadamente, Prado Jr. insistem na unicidade da filosofia wittgensteiniana, resta saber "se e como uma tensão entre dizer/mostrar ainda pode ter lugar quando se toma radicalmente a linguagem como práxis, como forma de vida" (MARTINS, 2012: 100). Olhar demoradamente para as cenas de alteridade parece ser uma maneira de perceber essa tensão em toda sua potência de crítica ao dogmatismo.

Como vimos, Wittgenstein oferece uma percepção da linguagem como vida, sendo a linguagem, tanto quanto a vida, imprevisível. Os sentidos são construídos no jogo, o que se mostrou numa filosofia marcada pela observação naturalista (GEBAUER: 2013: 73). Ele rejeita aquilo que é obscuro e sempre precariamente explicado na concepção mentalista e põe em discussão inclusive a possibilidade de uma linguagem privada para as sensações como dor, inferindo daí que todo significado é público. É a observação minuciosa das ações que importa para revelar as sequências adequadas de lances num jogo de linguagem. Importa ver também que o mundo está em constante reconstrução, e essa reconstrução ocorre não só pelo pensamento, mas sobretudo pela aquisição de habilidades, de verdadeiras "técnicas" que os adultos disponibilizam às crianças nos gestos, no olhar, no tom de voz... E elas "aprendem a fazer igual” (GEBAUER: 74-77). Os sentidos não estão lá, disponíveis desde sempre. As regras são aprendidas e assim chegamos ao bom lance no jogo. Olhar para as crianças (e para os loucos, os 
estrangeiros, os orientais etc.) é uma maneira de ver as regras ainda não estabilizadas. É quando se mostra a "coisa" da linguagem, nos termos de Agamben, que agora retomo.

Foi preciso aprofundar nosso entendimento sobre infância e isso fizemos a partir das reflexões de Agamben, que nos fala justamente de uma reflexão sobre a infância que o conduziu à pesquisa sobre a voz humana (ou sobre a sua ausência), levando-o à percepção da infância como uma "experiência que se sustém somente na linguagem" (AGAMBEN, 2014: 11). A infância mostra-se assim um lugar privilegiado para um aprofundamento sobre as questões do significado (e da experiência, e da aprendizagem) e isso não passou despercebido a Wittgenstein.

Se a condição própria de cada pensamento é avaliada segundo o seu modo de articular o problema dos limites da linguagem, o conceito de infância é, então, uma tentativa de pensar estes limites em uma direção que não é aquela, trivial, do inefável. O inefável, o "inconexo" [irrelato] são de fato categorias que pertencem unicamente à linguagem humana: longe de assinalar um limite da linguagem, estes exprimem seu invencível poder pressuponente, de maneira que o indizível é precisamente aquilo que a linguagem deve pressupor para poder significar. Ao contrário, o conceito de infância é acessível somente a um pensamento que tenha efetuado aquela «puríssima eliminação do indizível na linguagem» que Benjamin menciona em sua carta a Buber. A singularidade que a linguagem deve significar não é um inefável, mas é o supremamente dizível, a coisa da linguagem. (AGAMBEN, 2014: 11)

Parece plausível, então, como já se sugeriu, relacionar infância em Wittgenstein à "relação entre experiência e linguagem" de Agamben (p. 11), para quem "[é] suficiente seguir com atenção o movimento do pensamento kantiano para dar-se conta de que o experimento da razão pura não pode ser outro senão um experimentum linguae" que busca na autorreferencialidade, isto é, na própria linguagem, os seus limites. Pensa-se, assim, com Wittgenstein, e também com Agamben, sobre o que significa que exista a linguagem, esta relação entre língua e discurso, pois

para um ser cuja experiência da linguagem não se apresentasse desde sempre cindida em língua e discurso, um ser que já fosse, portanto, sempre falante e estivesse sempre em uma língua indivisa, não existiriam nem conhecimento, nem infância, nem história: ele seria desde sempre imediatamente unido à sua natureza linguística e não encontraria em nenhuma parte uma descontinuidade e uma diferença nas quais algo como um saber e uma história poderiam produzir-se. A dupla articulação em língua e discurso parece, pois, constituir a estrutura específica da linguagem humana, e somente a partir desta adquire seu sentido próprio a oposição de dýnamis e enérgeia, de potência e ato, que o pensamento de 
Aristóteles deixou como herança à filosofia e à ciência ocidental (AGAMBEN, 2014: 14).

Agamben lembra, a partir dessas reflexões, a proposta de Wittgenstein em sua Conferência sobre Ética:

\begin{abstract}
Então, o que temos em mente e o que tentamos expressar quando sentimos a tentação de usar expressões como "bom absoluto", "valor absoluto", etc.? Sempre que tento esclarecer isto para mim é natural que recorra a casos nos quais, sem dúvida, usaria tais expressões (...) Quando trato de concentrar-me no que entendo por valor absoluto ou ético, encontro-me numa situação semelhante. Em meu caso, ocorre-me sempre que a ideia de uma particular experiência se apresenta como se fosse, em certo sentido, e de fato é, minha experiência par excellence e por esta razão, ao dirigir-me agora a vocês, usarei esta experiência como meu primeiro e principal exemplo (como já disse, isto é uma questão totalmente pessoal e outros poderiam dar outros exemplos mais chamativos). Na medida do possível, vou descrever esta experiência de maneira que faça vocês invocarem experiências idênticas ou similares a fim de poder dispor de uma base comum para nossa investigação. Creio que a melhor forma de descrevê-la é dizer que, quando eu a tenho, assombro-me ante a existência do mundo. Sinto-me então inclinado a usar frases tais como "Que extraordinário que as coisas existam" ou "Que extraordinário que o mundo exista" (LE)
\end{abstract}

Isso, todavia, corresponde ao maravilhar-se com a existência da própria linguagem. Ora, a proposta de Wittgenstein, observa Agamben, é um experimentum linguae com o qual podemos prosseguir perguntando (e respondendo):

Se a expressão mais adequada para a maravilha da existência do mundo é a existência da linguagem, qual será então a expressão justa para a existência da linguagem?.

A única resposta possível a esta pergunta é: a vida humana enquanto ethos, enquanto vida ética. Buscar uma pólis e uma oikía que estejam à altura desta comunidade vazia e impresumível, esta é a tarefa infantil da humanidade que vem. (AGAMBEN, 2014: 17)

A tarefa parece que será tanto mais difícil quanto mais insistirmos na anulação da alteridade, pois nos parece impossível falar de ethos, pólis e oikía sem considerar o Outro. Neste espaço a que chamamos Ocidente, a dicotomia sujeito/objeto tornou-se um problema que se repercute nas instituições em geral, mas sobretudo naquelas que pretendem lidar diretamente com as questões epistêmicas. Em Agamben, ainda uma vez, encontramos os efeitos da modernidade sobre essas questões: 
Em sua busca pela certeza, a ciência moderna abole esta separação [entre experiência e ciência, saber humano e saber divino] e faz da experiência o lugar - o "método", isto é, o caminho - do conhecimento. Mas, para fazer isto, deve proceder a uma refundição da experiência e a uma reforma da inteligência, desapropriando-as primeiramente de seus sujeitos e colocando em seu lugar um único e novo sujeito. Pois a grande revolução da ciência moderna não consistiu tanto em uma alegação da experiência contra a autoridade (do argumentum ex re contra o argumentum ex verbo, que são, na realidade, inconciliáveis) quanto em referir conhecimento e experiência a um sujeito único, que nada mais é que a sua coincidência em um ponto arquimediano abstrato: o ego cogito cartesiano, a consciência (AGAMBEN, 2014: 28).

Uma vez que a certeza se instale, finda a experiência. O que significa dizer, finda a infância. Em diálogo com o excerto acima, umas linhas retiradas de Cultura e valor, na reflexão sobre nossa civilização, quanto a sua hýbris:

O homem - e talvez os povos - para admirar, tem de despertar. A ciência é uma maneira de o voltar a fazer adormecer (VB, p. 19).

A terapia filosófica de Wittgenstein não se constrói apenas na crítica às dicotomias e à certeza. Há uma nova e crucial percepção do instante, do tempo. Para um aprofundamento da questão do tempo em Wittgenstein, recorremos ainda ao pensamento de Agamben, no ensaio Tempo e História, onde adverte: "é chegado agora o momento de trazer à luz o conceito de tempo implícito na concepção marxista da história" (AGAMBEN, 2014: 109), concepção que, como se sabe, tem alguma implicação nos escritos da maturidade de Wittgenstein ${ }^{24}$. Contra a concepção circular e contínua de tempo da antiguidade greco-romana, segundo Aristóteles "número do movimento conforme o antes e o depois" (Ibidem, p. 111), há a experiência cristã do tempo, uma linha reta que vai do Gênese ao Apocalipse. Enquanto no mundo clássico o tempo é sem direção, o tempo cristão tem uma direção e um sentido, da criação ao fim, tendo um ponto de referência central que é a encarnação de Cristo, "por isso Agostinho pode opor aos falsi circuli dos filósofos gregos a via recta do Cristo, à eterna repetição do paganismo, na qual nada é novo, a novitas cristã, em que tudo acontece sempre uma vez só” (Ibidem, p. 113). A idade moderna concebe o tempo laicizando o conceito do tempo cristão, "dissociado, porém, de toda ideia de um fim esvaziado de qualquer sentido que não seja o de um processo estruturado conforme o antes e

\footnotetext{
${ }^{24}$ Ver R. MONK, Wittgenstein: o dever do gênio, São Paulo, Companhia das Letras, 1995, parte III, cap. 11 .
} 
o depois" (ibidem, p. 115), de tal modo que "sob o influxo das ciências da natureza, 'desenvolvimento' e 'progresso', que traduzem simplesmente a ideia de um processo orientado cronologicamente, tornam-se as categorias-guia do conhecimento histórico" (AGAMBEN, 2014: 116). Com tal concepção do tempo, o homem se vê expropriado de sua dimensão própria, já que esta lhe impede o acesso a uma historicidade autêntica. Urge chegar a uma concepção mais autêntica da historicidade, mas isso não se fará sem uma crítica do instante. Citamos:

É na Gnose, nesta religião frustrada do Ocidente, que se manifesta uma experiência do tempo radicalmente antitética no que se refere às experiências grega e cristã. Ao círculo da experiência grega e à linha reta do cristianismo, ela contrapõe uma concepção cujo modelo espacial pode ser representado por uma linha partida. Deste modo ela alveja precisamente o que permanece inalterado tanto na antiguidade clássica quanto no cristianismo: a duração, o tempo pontual e o contínuo. (...)

Também no Pórtico ${ }^{25}$ a antiguidade em seu ocaso parece superar a própria concepção do tempo. Esta superação manifesta-se como uma recusa ao tempo astronômico do Timeu, imagem da eternidade, e à noção aristotélica do instante matemático. O tempo homogêneo, infinito e quantificado, que divide o presente em instantes inextensos, é, para os Estoicos, o tempo irreal, cuja experiência exemplar se encontra na expectativa e no diferimento. A subserviência a este tempo inapreensível constitui a enfermidade fundamental que, com o seu adiamento infinito, impede a existência humana de possuir a si mesma como algo único e completo ("maximum vitae vitium est, quod imperfecta semper est, quod aliquid in illa differtur"). Defronte a ela o estoico coloca a experiência liberadora de um tempo que não é algo de objetivo e subtraído ao nosso controle, mas brota da ação e da decisão do homem. O seu modelo é o cairós, a coincidência brusca e improvisa na qual a decisão colhe a ocasião e realiza no átimo a própria vida (AGAMBEN, 2014: 121-22, grifo nosso).

O conceito de tempo implícito na concepção marxista da história reclama para o homem não um lugar passivo, do ser-no-tempo, mas a "dimensão geral do homem enquanto Gattungswesen, enquanto ser capaz de um gênero, isto é de produzir-se originalmente" (Ibidem, 118) como indivíduo universal a partir da práxis, "da atividade concreta como essência e origem (Gattung) do homem" (Ibidem, p. 119). A apreensão do agora como interrupção da cronologia é uma necessidade.

\footnotetext{
${ }^{25}$ Nos escritos originais de Agamben, Stoa, do grego Stoá ou 'pórtico', em referência à doutrina dos estóicos, pois Zenão de Cício (335-264), seu fundador, ensinava sob um pórtico, em Atenas. O termo 'pórtico' designa, por metonímia, o Estoicismo (Informação do tradutor, p. 121).
} 
É importante marcar que algo bastante próximo à reflexão de Agamben já comparece na crítica de Wittgenstein à ideia de progresso, ideia que, em alguma medida, desabilita uma visão perspectiva:

A nossa civilização é caracterizada pela palavra "progresso". Fazer progressos não é uma das suas características, o progresso é, mais propriamente a sua forma. Ela é tipicamente construtora. Ocupa-se em construir uma estrutura cada vez mais complicada. [...]

Não estou interessado na construção de um edifício, mas sim em ter uma visão clara dos alicerces dos edifícios possíveis.

Assim, não viso o mesmo alvo que os cientistas e a minha maneira de pensar é diferente da deles. (VB, p. 21)

A filosofia de Wittgenstein estabelece, por meio de sua percepção da importância da temporalidade na construção dos sentidos, uma crítica à ciência moderna, e à própria filosofia, naquilo que tornou possível uma ilusão de certeza e conhecimento que, buscando unir experiência (a partir do método) e ciência, saber humano e saber divino que se conciliam num ego cogito cartesiano, a saber, a consciência abstrata e impalpável que, no entanto, tem tantas implicações, estas palpáveis, para as nossas práticas mais comuns.

Uma cena bastante conhecida na biografia de Wittgenstein pode nos ajudar a compreender que, para ele, a filosofia só tem sentido se tem reflexos em nossas vida, levando-nos a arejar nossos pensamentos. Trata-se da cena em que ele repreende seu jovem aluno e amigo Norman Malcolm por se deixar levar por uma frase "perigosa" sobre o "caráter nacional britânico". Comentando esse episódio, Perloff abre sua obra A escada de Wittgenstein:

De que serve estudar filosofia se ela não melhora seu modo de pensar sobre as questões importantes do cotidiano? Essa é a pergunta premente que Wittgenstein fez a si mesmo durante toda a sua carreira de filósofo. Já em 1913, em Notes on Logic, ele escrevia: "Em filosofia não há dedução. Ela é puramente descritiva. A filosofia não oferece imagens mentais da realidade" (PERLOFF, 2008: 20).

Da mesma forma podemos dizer: de que adianta ler Wittgenstein se isso não nos ajudar a pensar nas questões prementes da educação, tanto de jovens quanto de adultos, questão tão enfaticamente trazida pelo filósofo? A filosofia de Wittgensein tem inspirado não poucos a pensarem não apenas em teorias, mas em práticas que nos auxiliem em nosso cotidiano de sala de aula. 
Maruyama (2001) observa a recorrência de cenas de alteridade adulto vs criança, apontando em seus estudos que o objetivo de Wittgenstein é "examinar enigmas filosóficos" por meio dessas cenas. Seu estudo conclui que Wittgenstein mostra, sem precisar dizer, que a filosofia pode ser uma atividade libertadora. Em artigo intitulado "Wittgenstein's Children: Some Implications for Teaching and Otherness", de 1998, Maruyama destaca dois "tipos" de cenas em que aparecem crianças na filosofia madura de Wiitgenstein: o primeiro deles chama a atenção para a diferença qualitativa entre a linguagem do adulto e a da criança e o segundo ressalta o problema da invisibilidade da alteridade em nossas relações de ensino/aprendizagem. A diferença qualitativa discute a ideia destacada pelo próprio Wittgenstein de ver a criança como um mini-adulto, alguém já familiarizado com as regras. A segunda discussão é encaminhada para o nosso desejo de transformar o aprendiz em nós mesmos. Ambas as discussões, pensamos, fazem sentido em quaisquer níveis de ensino, quando a autoridade, o professor, simplesmente deixa de se questionar a respeito da alteridade e do lugar ocupado por este interlocutor, talvez pelo hábito já tão arraigado da objetivação. Diversamente da maneira de conhecer da modernidade ocidental, para quem "a forma do Outro é a coisa", Viveiros de Castro nos conta a respeito de um "oposto polar da epistemologia objetivista" numa forma de vida que, por contraste, lança luz sobre as nossas próprias tendências e propensões:

O xamanismo ameríndio parece guiado pelo ideal inverso. Conhecer é personificar, tomar o ponto de vista daquilo que deve ser conhecido - daquilo, ou, antes, daquele; pois o conhecimento xamânico visa um "algo" que é um "alguém", um outro sujeito ou agente. A forma do Outro é a pessoa (VIVEIROS DE CASTRO, 2011: 358).

Muitos dos dilemas em educação parecem ter relação com nossa busca por algo inacessível, ideal, o que acaba por nos impedir de ver até mesmo o que está próximo a nós. Gottschalk (2013), pesquisadora na área de educação, traz um contraponto entre Wittgenstein e três outros modelos filosóficos de ensino baseados na tradição filosófica ligada a Locke, Agostinho e Kant. A pesquisadora lembra que tradicionalmente o paradigma apoiado no mentalismo é aceito ainda que não encontremos respostas para compreender como ele opera (Gottschalk, 2013: 667). Diante do paradoxo do ensino visitado nessa discussão, das inconsistentes tentativas de resposta aos problemas da aprendizagem e da nossa 
incompreensão sobre como ocorre a aprendizagem, tanto sob um viés mentalista quanto sob o viés behaviorista, Gottschalk recorre à filosofia de Wittgenstein, sobretudo às cenas do ensino, para a dissolução desse paradoxo. Apontando que "a dificuldade nos modelos filosóficos de ensino é a de ignorar as diferentes funções desempenhadas pela nossa linguagem" (Gottschalk, 2013: 672), a pesquisadora enfatiza que nenhum saber é meramente proposicional, visando a uma realidade que à linguagem cabe apenas descrever, pois todos os saberes pressupõem um modo de agir. Em suas palavras:

Somos treinados a soletrar as palavras de um determinado modo, a saber, da esquerda para a direita, lemos de cima para baixo, enfim, processos de memorização são acompanhados de ações enraizadas em nossas formas de vida, e que se tornam as condições de construção do conhecimento significativo, permitindo que "sigamos em frente". Podemos, então, responder tanto aos sofistas como aos platônicos: o conhecimento é sim possível, mas seus fundamentos devem ser aprendidos, o que pressupõe o treinamento em diversas técnicas de natureza convencional (GOTTSCHALK: 2013: 673-4).

\section{E quanto a isso Wittgenstein lembra que}

Enquanto continuar a existir um verbo "ser" que parece funcionar como "comer" e "beber", enquanto tivermos os adjetivos "idêntico", "verdadeiro", "falso", "possível", enquanto continuarmos a falar de um fluir do tempo, de uma vastidão do espaço, etc., etc., etc., continuaremos a tropeçar nas mesmas perplexidades e a olhar espantados para algo que nenhuma explicação parece ser capaz de esclarecer.

E, além disso, isto satisfaz um desejo de transcendência, visto que na medida em que as pessoas pensam que lhes é possível ver os "limites da compreensão humana", acreditam, evidentemente, que lhes é possível ver para além desses limites. (VB, p. 31-32)

Há, assim, na filosofia madura de Wittgenstein um chamado para olharmos aquilo que está tão perto de nós e que acabamos por não ver. Sobre isso, Luiz Henrique Lopes dos Santos comenta na entrevista já citada:

Qual é o lema das Investigações? Nada está oculto, não é? Você dirá: Bom, então por que as pessoas não veem? Não veem porque está perto demais e é muito complexo. Você tem um emaranhado de relações entre símbolos, entre práticas simbólicas, entre usos diferentes da linguagem. Eles são visíveis, estão aí, mas são tão complexos e numerosos que eu não tenho uma visão panorâmica e perspícua deles (CORNELLI \& CARVALHO, 2013: 35).

Refletir sobre a alteridade é refletir sobre a linguagem, tão fortemente presente entre nós e sem a qual não nos constituiríamos como espécie "homo sapiens loquendi, homem que sabe e pode falar (e, portanto, também não falar)" 
(AGAMBEN, 2014: 14). O desejo de transcendência que tanto nos inquieta é um desejo inscrito na linguagem e em sua parte não dita, na in-fância do homem, lembrando ainda uma vez Agamben. A tentativa de aprisionar a linguagem numa única interpretação, embora muitas vezes traga uma sensação de que agora podemos compreender e conhecer, revela-se, no entanto, sempre frustrada. Ouçamos ainda uma vez as palavras de Wittgenstein em mais uma provocação em referência à nossa tranquila aceitação sobre explicações que não explicam:

Um matemático tem de ficar horrorizado com meus comentários matemáticos, já que sempre foi treinado para evitar a indulgência com pensamentos e dúvidas do tipo que desenvolvo. Ele aprendeu a considerá-las algo desprezível e, para usar uma analogia da psicanálise (este parágrafo faz lembrar Freud), adquiriu uma aversão a elas como infantis. Isto é, eu exibo todos os problemas que uma criança que está aprendendo aritmética etc. acha difíceis, os problemas que a educação reprime sem solucionar. Digo a essas dúvidas reprimidas: vocês estão inteiramente corretas, continuem a perguntar, exijam esclarecimento! (PG, p. 302).

As perguntas que as "dúvidas reprimidas" fazem (e aqui nos perguntamos se seria possível dizer 'as dúvidas que as crianças reprimidas não fazem'), os jogos de linguagem nos mostram, referem-se, muitas vezes, à ligação entre o real e sua representação pela linguagem. Quando não damos mais conta de explicar, declaramos a dúvida impertinente e dela desistimos. Para solucionar as questões cujas respostas não nos parecem acessíveis, recorremos, muitas vezes à anulação do que nos é estranho, demonstrando que nos tornamos prisioneiros de um jogo a que talvez possamos chamar "jogo da objetivação". Contra ele, e para ir em frente, precisamos aprender outros jogos, o que, como vimos em Nietzsche e Deleuze, é também um chamado político. E voltamos à vida.

\section{1}

\section{Jogos de linguagem e forma de vida}

A criança aprende acreditando no adulto. A dúvida vem depois da crença.

L. Wittgenstein.

Com os jogos primitivos, como o jogo imaginado entre construtores (PU, $\S$ 2), por exemplo, e o jogo do ensino ostensivo (PU, §1), Wittgenstein nos faz pensar sobre a técnica que se aprende juntamente com a linguagem, com o treino visto na repetição que ocorre naturalmente no cotidiano. Tanto na linguagem dos 
construtores quanto na das crianças que estão sendo iniciadas na linguagem, os jogos são parte da vida. Todas essas cenas trazidas para a nossa consideração não chegam, como vimos, a nenhuma conclusão, mostrando que o pensamento não alcança muito mais longe do que aquilo que vemos, como o filósofo deixa entrever nas considerações feitas no $§ 68$ das Investigações sobre o que seria um jogo:

O que é ainda um jogo é o que não o é mais? Você pode indicar os limites? Não. Você pode traçar alguns: pois ainda não foi traçado nenhum. (Mas isso nunca o perturbou, quando você empregou a palavra "jogo".) (PU, § 68)

Vejamos algumas cenas selecionadas do nosso extenso corpus. Esta análise procura mostrar o espaço em branco que fica no texto de Wittgenstein, mostrar a sua maneira de não dizer, mais do que propriamente de dizer o que seja, finalmente, um jogo de linguagem ou uma forma de vida, pois isso nos pareceria trair o espírito dessa escrita. Afinal, como se disse, aprendemos com Prado Jr. que é preciso ter o cuidado de não "ampliar exageradamente a dimensão cognitiva da ideia de jogo de linguagem" (PRADO Jr., 2004: 31)

\section{Cena 1}

Pense também em ensinar uma criança a entender palavras mostrando-lhe objetos e proferindo palavras. - Mas qual é o critério de entendimento nesse caso? Certamente que a criança aplique as palavras corretamente. Ela adivinha regras? - Na verdade, devemos nos perguntar se devemos chamar esses signos e emissões de palavras de "definições". O jogo da linguagem ainda é muito simples e a definição ostensiva não tem nesse jogo de linguagem o mesmo papel que nos jogos mais desenvolvidos. (Por exemplo, a criança ainda não pode perguntar "Como se chama isso?") Mas não há nenhuma fronteira nítida entre as formas primitivas e as mais complicadas. Eu não saberia o que posso e o que ainda não posso chamar de "definição".

Eu também poderia dizer a respeito de uma criancinha: "Ela sabe usar a palavra, ela sabe como é aplicada". Mas só vejo o que significa se pergunto "qual é o critério para esse conhecimento?". Nesse caso, não é a capacidade de enunciar regras (PG, §26- grifos nossos).

Os jogos de linguagem exigem dos jogadores uma execução. Vemos que a criança ainda bem pequena pode reconhecer a ação do adulto sobre os objetos e imitá-la. O que se mostra aqui é que bem antes de poder repetir a fala do adulto, a criança já teve que dominar algumas técnicas realizadas em ações públicas (a ação de apontar, por exemplo) que ocorrem como o aprendizado de regras de outro jogo qualquer. A compreensão dessas regras, antes de ser ato cognitivo, se mostra 
na igualdade de ações, na ação prática que se expressa na sempre renovada concordância das ações do aprendiz e do mestre.

\section{Cena 2}

(...) A criança aprende esta linguagem, sendo treinada pelos adultos a usá-la. Utilizo a palavra "treinar" de uma maneira rigorosamente análoga àquela em que falamos de treinar um animal para fazer certas coisas. Isso é feito recorrendo a exemplos, à recompensa, à punição, e coisas semelhantes. Parte deste treino consiste em apontar para uma pedra de construção, dirigir a atenção da criança para ela e pronunciar uma palavra. Chamarei a esta maneira de proceder, ensino demonstrativo de palavras. Na prática do uso desta linguagem, um homem grita as palavras como ordens, o outro age de acordo com elas. Mas a aprendizagem e o ensino desta linguagem conterão o seguinte procedimento: a criança apenas «nomeia» objetos, isto é, pronuncia as palavras de uma linguagem, quando o professor aponta para os objetos. De fato, encontrar-se-á um exercício ainda mais simples: a criança repete palavras que o professor pronuncia. $(\mathrm{BB}, \S 1-$ grifos nossos)

Esta cena, ainda que trate, como a cena anterior, do ensino ostensivo das palavras, mostra que o fazemos de forma a agir com a alteridade criança do mesmo modo como agimos em relação à alteridade animal, o que não é pouco dizer no caso de uma forma de vida que, diferentemente, por exemplo, da forma de vida ameríndia - em que os animais são "frequentemente concebidos como ligados por afinidade aos humanos" (VIVEIROS DE CASTRO, 2011: 385) -, guarda em sua mitologia de base a dicotomia humano $v s$ animal, reservando ao humano uma posição de supremacia em relação aos animais, pois assume via de regra que só os humanos têm alma. Para seguir com o contraste que contrailumina as nossas próprias tendências, cabe citar que, no estranhamento ocorrido na chegada dos europeus às terras indígenas, Viveiros de Castro observa, a partir de uma anedota narrada por Lévi-Strauss:

Para os europeus, tratava-se de decidir se os outros tinham uma alma; para os índios, de saber que tipo de corpo tinham os outros. O grande diacrítico, o sítio da diferença de perspectiva para os europeus, é a alma (os índios são homens ou animais?); para os índios, é o corpo (os europeus são homens ou espíritos?). Os europeus não duvidavam que os índios tivessem corpos - animais também os têm; os índios, que os europeus tivessem alma - animais também os têm (VIVEIROS DE CASTRO, 2011: 381).

\section{Cena 3}

Uma criança sabe que cor a palavra "azul" significa». Saber isso não é assim tão simples (UG, §545) 
Uma criança tem de aprender a utilizar as palavras referentes às cores antes de poder perguntar o nome de uma cor (UG, §548).

Uma criança que aprendeu a utilizar a palavra (para nomes de cores) não está "segura de que na sua língua esta cor se chama assim". Nem se pode dizer que, quando ela está aprendendo a falar, ela aprenda que a cor se chama assim em português, ou ainda que ela sabe isso quando aprendeu a utilizar a palavra (UG, $\$ 527$ - grifos nossos).

Ainda no jogo de nomear, mas especificamente em relação às cores, Perloff encontra um interessante modo de mostrar a associação do caráter perspectivo da filosofia wittgensteiniana que se torna aparentada com a arte quando não se desfaz de uma subjetividade necessária no jogo. Como a arte, essa filosofia, ao negar a estabilidade do significado, mostra-se em sua irredutibilidade.

Como é que uma criança sabe que "azul" às vezes é um descritor fixo (Como na frase "já se pode ver o céu azul de novo"), às vezes uma classe que inclui vários subconjuntos (por exemplo, tonalidades de azul), às vezes uma referência para a habilidade de produzir cores que coincidam com as da natureza e assim por diante? Porque - e Wittgenstein vai assim nos mostrando pouco a pouco - a língua não tem essência; ela é uma construção cultural complexa, cujas variáveis são articuladas de acordo com a intersecção particular de alguém com ela. (PERLOFF, 2008: 98)

A complexidade da linguagem não cabe, portanto, em nenhuma explicação. $\mathrm{O}$ fato de o jogo de mostrar e de nomear ser primitivo - e por isso exigir menos dos jogadores - não o torna, ainda assim, possível de ser teorizado (ou objetivado). A complexidade da significação mostrada por Wittgenstein em exemplos tão corriqueiros faz lembrar o ideal de subjetividade característico no xamanismo como epistemologia indígena que, segundo Viveiros de Castro

(...) encontra-se em nossa civilização confinado àquilo que Lévi-Strauss chamava de parque natural ou reserva ecológica no interior do pensamento domesticado: a arte. O pensamento selvagem foi confinado oficialmente ao domínio da arte; fora dali, ele seria clandestino ou "alternativo". Valorizada como seja a experiência artística, ela nada tem a ver com o experimento científico: a arte é inferior à ciência como produtora de conhecimento. Ela pode ser emocionalmente superior, mas não é epistemologicamente superior (VIVEIROS DE CASTRO, 2011: 487-88).

Como vimos, Wittgenstein reclama para sua filosofia um lugar junto à poesia, mostrando assim eleger a possibilidade de um pensamento em expansão um pensamento que poderia ser tomado como selvagem, nos termos da passagem acima. Importa sublinhar aqui também a confluência entre o selvagem, a arte e a infância: em Wittgenstein, como em outros pensamentos perspectivistas, esses são 
espaços de práticas experimentais e menos reguladas, que por isso mesmo dão a ver o sem fundo de nossas próprias convicções e hábitos arraigados.

Seja como for, quando nós ocidentais treinamos ou iniciamos as crianças nesses hábitos e convicções, o jogo de nomear, com toda a sua enganosa aparência de conexão objetiva entre palavras e coisas, parece ocupar um lugar de destaque. Quando palavras como "não" e "talvez", que, para início de conversa, não fazem referências a objetos, começam a ser postas em questão, o jogo de nomear apresentado no ensino ostensivo torna as explicações essencialistas ainda mais precárias. Como as crianças aprendem efetivamente a usar as palavras?

Vejamos uma cena.

\section{Cena 4}

O que significa "entender uma palavra"?

Dizemos a uma criança "Não, chega de açúcar" e o tiramos da frente dela. Assim ela aprende o significado da palavra "não". Se, enquanto dizíamos as mesmas palavras houvéssemos lhe dado um pedaço de açúcar, ela teria aprendido a entender a palavra de maneira diferente. (Dessa maneira, ela aprendeu a usar a palavra, mas também a associar um sentimento particular a ela, a experimentá-la de uma maneira particular.)

O que constitui o significado de uma palavra como "talvez"? Como uma criança aprende o uso da palavra "talvez"? Ela pode fazê-lo no mesmo tom de voz que o adulto. (Isso é um tipo de jogo) Em tal caso, às vezes se pergunta: ela já entende a palavra "talvez" ou está apenas repetindo? - O que demonstra que ela realmente entende a palavra? - Bem, o fato de que a usa em circunstâncias particulares, de uma maneira particular - em certos contextos e com uma entonação particular.

O que significa "entender a palavra "talvez"? Eu entendo a palavra "talvez"? - e como julgo que sei? Bem, algo assim: sei como é usada, posso explicar seu uso a alguém, dizer descrevendo-a em casos inventados. Posso descrever as ocasiões de seu uso, sua posição nas sentenças, a entonação que tem no discurso. Naturalmente isso só significa que "Entendo a palavra "talvez"” equivale a: "Sei como é usada, etc."; não que eu tente chamar à mente toda a sua aplicação para responder se entendo a palavra. Mais provavelmente, eu reagiria a essa questão imediatamente com a resposta "sim", talvez depois de ter dito a palavra para mim mesmo outra vez e como se, por assim dizer, tivesse me convencido de que é familiar ou, então, pudesse pensar em uma única aplicação e pronunciasse a palavra com a entonação correta e um gesto de incerteza. $\mathrm{E}$ assim por diante. (PG, §28 - grifos nossos)

Em Glock, encontramos as seguintes observações:

Um dos usos que Wittgenstein dá aos jogos de linguagem reais é enfatizar a natureza heterogênea da linguagem. Outro é sustentar que a confusão FILOSÓFICA se origina de um entrecruzamento de jogos de linguagem, isto é, da utilização de palavras de um jogo de linguagem conforme as regras de outro jogo. Um outro ainda é afirmar que, assim como qualquer jogo, os jogos de linguagem 
são AUTÔNOMOS; não se justificam por objetivos externos, ao contrário de uma atividade como cozinhar. (GLOCK, 1988: 228)

Trazendo outras classes de palavras que não o substantivo para a discussão sobre os jogos de linguagem, Wittgenstein aprofunda a questão da precariedade das explicações essencialistas. Abre, com isso, um espaço para questionamentos ainda maiores; sobre a compreensão, por exemplo. A esse respeito, Glock lembra que:

No mentalismo, a comunicação é, ou um processo causal pelo qual os falantes produzem em seus ouvintes ideias semelhantes às que associam a uma palavra, ou uma questão de tradução, um processo em que os falantes traduzem em sons o seu vocabulário mental interno, para que os seus ouvintes os retraduzam para sua própria linguagem privada. (GLOCK, 1988: 90)

Descartar o mentalismo como explicação implica mostrar como, uma vez inseridos em acordos de nossa forma de vida, separamos aquele que não reage conforme ao que se espera. Ou seja: compreender é manifestar um comportamento que se espera naquele jogo. Reagir diversamente põe em risco a aceitação do divergente por parte daquele grupo que comunga de uma mesma forma de vida; o indivíduo que diverge torna-se marginalizado. Glock aponta que, segundo Wittgenstein, compreender é uma capacidade que se manifesta de três formas: "no modo como usamos a palavra, no modo como reagimos quando outros a utilizam, e no modo como a explicamos quando somos solicitados a fazêlo" (GLOCK, 1988: 92). Se queremos saber sobre o significado de uma palavra, devemos olhar mais atentamente para a maneira como nos comportamos em relação às palavras.

\section{Cena 5}

(...) As crianças da tribo aprendem os números do seguinte modo: são-lhes ensinados os signos de 1 a 20 como em 2) e aprendem a contar filas de contas em número não superior a 20, ao ser-lhes dada a ordem: «Contem-nas». Quando ao contar o aluno chega a 20, sugere-se-lhe com um gesto que continue, dizendo a criança (pelo menos na maior parte dos casos) «21». De modo análogo, faz-se que as crianças contem até 22 e até números maiores, não desempenhando, nestes exercícios, qualquer número particular o papel predominante de um último número. $\mathrm{O}$ último estádio do treino consiste em ordenar à criança que conte um grupo de objetos, em número bastante superior a 20 . Se uma criança não responder ao gesto que lhe sugere a continuação da contagem, é separada das outras e tratada como louco (BB, $\S 30$ - grifos nossos) 
Para a análise do trecho em tela, recorremos a Cavell, que ressalta a maneira como a incapacidade de comunicação afeta a sensação de poder do indivíduo quando seu interlocutor não capta sua mensagem, e como essa falta de entendimento se reflete na expectativa do sujeito de que a reação do outro seja a mesma que a dele e, caso isso não aconteça, ocorra a excomunhão da alteridade. Quando há a necessidade de que o Outro seja o Eu e isso não se completa, o processo de comunicação é diretamente afetado, o que causa o estranhamento da reação, desnaturalizada e esvaziada de compreensão, tendo em vista que o Eu choca-se consigo mesmo logo depois de chocar-se, também, com o Outro - e ambas as situações não eram esperadas. Cavell reflete no peso que essas situações têm para a infância:

As histórias em que Wittgenstein utiliza o imaginário matemático, todas essas histórias - a do comerciante de madeira, ou outras ainda, a propósito de pessoas que "medem" com réguas elásticas, que estabelecem listas na maior das desordens, que não se importam em saber se são enganadas, que "calculam" perguntando a alguém um número qualquer - podem ser lidas, uma vez vistas de uma certa distância, como se seus personagens fossem crianças. Numa obra que fala tão fundamentalmente de ensino, e na qual a criança é uma figura central, convém ressaltar o fato de que nós começamos nossas existências como crianças (CAVELL, [1979] 2012: 197).

Por conseguinte, Cavell entende que este é o propósito da filosofia: um confronto que desloca o indivíduo de sua zona de conforto marcada pela convenção e lhe oferece a oportunidade do senso crítico, para que o sujeito esteja sempre em contato consigo, estabelecendo esse jogo de alteridades entre o Eu que também contém o Outro:

[...] Convoco, em minha imaginação, um conjunto de critérios de minha cultura, a fim de confrontá-los com minhas palavras e com minha vida, tanto no modo como os pratico, quanto no modo como posso imaginá-los; tratando-se, ao mesmo tempo, de confrontar minhas palavras e minha vida - tal como os pratico - com a vida que as palavras de minha cultura podem imaginar para mim; confrontar a cultura a ela mesma, a partir do modo como ela vive em mim.

Esta me parece uma das tarefas que podem ser nomeadas filosofia. É também a descrição de algo que podemos chamar de educação. [...] E, a esta luz, a filosofia torna-se a educação dos adultos (CAVELL, [1979] 2012: 199).

Uma aproximação entre uma filosofia perspectivista e os estudos antropológicos, pode bem colaborar com isso que Cavell chama de "educação dos adultos". Para ilustrar, ouçamos uma explicação sobre a diferença entre a antropologia e a sociologia nas palavras de Viveiros de Castro: 
A antropologia é o estudo das relações sociais de um ponto de vista que não é deliberadamente dominado pela experiência e a doutrina ocidentais das relações sociais. Ela tenta pensar a vida social sem se apoiar exclusivamente nessa herança cultural. Se vocês quiserem, a antropologia se distingue na medida em que ela presta atenção ao que as outras sociedades têm a dizer sobre as relações sociais, e não, simplesmente, parte do que a nossa tem a dizer e tenta ver como é que isso funciona lá. Trata-se de tentar dialogar para valer, tratar as outras culturas não como objetos da nossa teoria das relações sociais, mas como possíveis interlocutores de uma teoria mais geral das relações sociais. Para mim, se há alguma diferença entre antropologia e sociologia, seria esta: o objeto do discurso antropológico tende a estar no mesmo plano epistemológico que o sujeito desse discurso (VIVEIROS DE CASTRO, 2011: 486 - grifo nosso).

O empenho de Wittgenstein em experimentos de pensamento que figuram cenas de alteridade encontra paralelo nesse empenho da antropologia em prestar atenção a outras formas de vida, de tal modo que a hierarquia entre sujeito e objeto se desestabilize: em vez de se perguntar como explicar esse comportamento estranho, reduzi-lo à minha teoria?, pergunta-se: o que o comportamento que me é tão estranho pode me ensinar? Frequentemente, no caso de Wittgenstein, a resposta é: pode me mostrar, sem propriamente dizer, os Weltbilder a que aderimos na práxis e pela práxis, sem que tenham passado por qualquer crivo intelectual ou cognitivo.

Nas cenas abaixo, Wittgenstein tematiza a necessidade de "aderir" ao jogo para que este possa ser ensinado.

\section{Cena 6}

Um aluno e um professor. O aluno não deixa que lhe expliquem nada porque interrompe continuamente com dúvidas, por exemplo, acerca da existência das coisas, significado das palavras, etc. O professor diz: "Deixa de me interromper e faz como eu te digo. Até agora as tuas dúvidas não fazem sentido algum" (UG, $\$ 310$ - grifos nossos).

Isto é, o professor pensará que esta pergunta não é de modo algum legítima.

Seria precisamente o mesmo se o aluno levantasse dúvidas quanto à uniformidade da natureza, portanto, sobre a justificação de argumentos indutivos. O professor pensaria que isso apenas os demorava, que dessa maneira o aluno ficaria parado e não faria progressos. - E teria razão. Seria como se alguém estivesse a procurar um objeto num quarto; abre uma gaveta e não o vê ali; depois fecha-a, espera e abre-a mais uma vez para ver se por acaso não está lá agora, e continua assim. Não aprendeu a procurar coisas. E, do mesmo modo, o aluno não aprendeu como fazer perguntas. Não aprendeu $o$ jogo que queremos ensinar-lhe (UG, §315).

Jogar um mesmo jogo implica uma aceitação tácita dos acordos feitos sobre uma forma de vida. Quando, no entanto, a base de um Weltbild é questionada, torna-se impossível jogar o mesmo jogo. Trazendo para as palavras de Prado Jr.: 
"a verdade de certas proposições aparentemente empíricas pertence ao nosso quadro de referência, isto é, à própria base de nosso Weltbild" (PRADO Jr., 2004: 31). O adulto, em suas relações com a criança, transmite-lhe muitas coisas e dentre essas, o quadro de referência. Jogar bem o seu jogo significa não indagar por suas bases, pois fazê-lo seria interromper o jogo (PRADO Jr., 2004: 30) ou mesmo impossibilitar que seja jogado, como mostra a cena acima. A reciprocidade encontrada entre a ideia de jogo de linguagem e forma de vida revela o que Cavell (2012: 190) denomina “concepção antropológica" na filosofia de Wittgenstein. Para formas de vida distintas, encontraremos também distintos Weltbilder que possibilitem as diferentes necessidades. No contraponto que elegemos privilegiar neste trabalho, vale citar ainda Viveiros de Castro:

É importante atentar para o fato de que os dois pontos de vista cosmológicos aqui contrastados - o que chamei de "ocidental" e o que chamei de "ameríndio" - são, do nosso ponto de vista, incompossíveis. Um compasso deve ter uma de suas pernas firme, para que a outra possa girar-lhe à volta. Escolhemos a perna correspondente à natureza como nosso suporte, deixando a outra descrever o círculo da diversidade cultural. Os índios parecem ter escolhido a perna do compasso cósmico correspondente ao que chamamos "cultura", submetendo assim a nossa "natureza" a uma inflexão e variação contínuas. A ideia de um compasso capaz de mover as duas pernas ao mesmo tempo - um relativismo finalizado seria assim geometricamente contraditória, ou filosoficamente instável (VIVEIROS DE CASTRO, 2011: 398).

Se, como lembra a fala de Deleuze em epígrafe, as crianças são nossos prisioneiros políticos, isso se dá, em larga medida, porque transformamos nosso Weltbild em Weltanschauung (PRADO Jr., 2004: 51).

\section{Cena 7}

Ensinamos a uma criança «isto é a tua mão», e não «isto talvez seja (ou provavelmente é) a tua mão». É assim que uma criança aprende os inúmeros jogos de linguagem relacionados com a sua mão. E investigar ou inquirir "se isto é realmente uma mão" nunca lhe ocorreu. Nem, por outro lado, ela aprende que sabe que isto é uma mão. (UG, $\S 374$ - grifo nosso)

Quando uma criança aprende a linguagem, aprende ao mesmo tempo o que deve e o que não deve ser investigado. Quando aprende que há um armário no quarto, não lhe ensinam a pôr em dúvida que aquilo que vê mais tarde ainda seja o armário e não apenas um adereço de cenário (UG, §472- grifo nosso).

As crianças não aprendem que existem livros, que existem poltronas; aprendem a ir buscar livros, a sentarem-se em poltronas, etc.

Mais tarde, evidentemente, surgem perguntas acerca da existência das coisas. "Existe o que se chama um unicórnio?", e assim por diante. Mas uma tal pergunta 
só é possível porque, em regra, não se apresenta a questão correspondente. Porque como é que alguém sabe como deve proceder para verificar a existência de unicórnios? Como se aprende o método para determinar se alguma coisa existe ou não? (UG, §476 - grifos nossos)

Com essas cenas, Wittgenstein mostra mais uma vez a precariedade das explicações essencialistas. Mais que isso, mostra que tanto a filosofia realista quanto a idealista, ao empreenderem esforços para cancelarem ou confirmarem seus pressupostos, demonstram compartilhar uma mitologia de base que confunde

fato e lógica, Weltbild e conhecimento racional ou positivo. Mitologia é, em ambos os casos, a palavra que significa uma ilusão de tipo especial - talvez até uma ilusão bene fondata praticamente. Aquela ilusão que é inevitável e inócua (e, mais do que isso, indispensável ao bom funcionamento da prática discursiva e da vida em comum). Ela arrisca, todavia, tornar-se Weltanschauung nas mãos do filósofo, realista ou idealista, que quer dar fundamento teórico ou dogmático ao humano e necessário desejo de segurança (PRADO Jr., 2004: 51).

As formas de vida, mostra a filosofia wittgensteiniana, possuem padrões pragmáticos que estabelecem seus próprios modelos de racionalidade, motivo pelo qual questionar um jogo de linguagem de um ponto de vista externo a ele buscando legitimá-lo ou desqualificá-lo não se constitui um caso de argumentação racional, mas de persuasão (GLOCK, 1998: 176). É preciso, no entanto, distinguir ilusão filosófica do erro para finalmente chegarmos ao entendimento do que seja loucura na filosofia madura de Wittgenstein, já que esse entendimento é essencial a um trabalho que se propôs discutir a ideia de forma de vida a partir de um panorama cosmológico distinto daquele que julgamos conhecer, o ocidental. O $\S$ 611 de Da Certeza traz a seguinte afirmação:

Quando se encontram dois princípios que não podem conciliar-se um com o outro, os que defendem um declaram os outros loucos e heréticos.

Um traço essencial para que se considere algo um erro é a possibilidade de ser corrigido (UG, $\S 156$ ), o que significa dizer que erro pressupõe regras (PRADO Jr., 2004: 54) enquanto a loucura (UG, §§ 217, 223, 281) se define em Wittgenstein como "cegueira para as regras", ou, nas palavras de Prado Jr., uma "espécie de erro incorrigível" que acompanha, no entanto, nosso entendimento são:

Se na vida estamos cercados pela morte, assim também na saúde do entendimento estamos cercados pela loucura (VB, p. 70). 
Em diálogo com essas considerações da filosofia madura de Wittgenstein, encontramos em Viveiros de Castro a seguinte apreciação do contraste entre as formas de vida ameríndias e as nossas:

\begin{abstract}
se os índios têm razão, então a diferença entre os dois pontos de vista não é uma questão cultural, e muito menos de mentalidade. Se os contrastes entre relativismo e perspectivismo ou entre multiculturalismo e multinaturalismo forem lidos à luz, não de nosso relativismo multicultural, mas da doutrina indígena, é forçoso concluir que a reciprocidade de perspectiva se aplica a ela mesma, e que a diferença é de mundo, não de pensamento.(VIVEIROS DE CASTRO, 2011: 398- grifo nosso).
\end{abstract}

Se as situações de alteridade radical - como estas entre "nós" e os índios - dão a ver que "na saúde do entendimento estamos cercados pela loucura", é porque não são diferentes formas de pensar que entram em jogo em tais situações, mas a própria consistência da vida, o próprio mundo vivido.

Aqui, como vemos, já estamos entrando no campo das certezas, pois delas derivamos nossa (in)capacidade de julgar o Outro louco ou são.

\title{
4.2
}

\section{Ensino e certeza}

A ambição é a morte do pensamento.

L. Wittgenstein

Para Wittgenstein, a "gramática" do verbo aprender é aparentada com a do verbo acreditar. Diz isso, pois, como vimos, uma criança, normalmente, não contesta os fatos que ensinamos a ela. Aprendemos acreditando na autoridade de quem nos ensina. A dúvida, quando existe, é posterior a acreditar (ou aprender). Olhar assim tão de perto para o aprendizado nos ajuda a perceber nossa dificuldade em compreender a falta de um fundamento último para nossas crenças. Argumentando sobre certezas, o filósofo toma o cuidado de distinguir o valor de algumas proposições empíricas frente a outras:

É claro que nem todas as nossas proposições empíricas têm o mesmo estatuto, já que se pode formular uma proposição e convertê-la de proposição empírica em norma de descrição.

Pense na investigação química. Lavoisier faz experiências com substâncias em seu laboratório e concluiu que acontece determinado fenômeno quando há combustão. Não diz que poderia acontecer de outro modo, noutra ocasião. Adquiriu uma imagem do mundo definida - não, evidentemente, uma que ele tivesse inventado: 
aprendeu-a em criança. Digo imagem do mundo [Weltbild] e não hipótese, porque é a fundação natural da sua pesquisa e assim não é sequer mencionada (UG, § 167).

Diante desses questionamentos sobre certeza, Prado Jr. (2004: 46-7) questiona como uma proposição pode ser considerada verdadeira ou falsa, se, de acordo com a filosofia de Wittgenstein, lógica e gramática mostram que, por essência, ela não pode ser nem verdadeira nem falsa. Prado Jr. (2004, 46-7) explica que, de acordo com o que aprendemos com essa filosofia em sua minuciosa análise da significação de verbos como "saber" e expressões como "ter certeza", a confusão entre certeza e crença advém do fato que a crença insinua-se sub-repticiamente "nas dobras da razão reflexionante" e cobra direitos iguais aos do Wissen (o saber). Prado Jr. então argumenta que para cada um dos truísmos de Moore ("Sei com certeza que tenho mãos, sei que tenho um corpo" etc.) Wittgenstein questionará "a ênfase que sublinha a expressão "sei”, pois ela

parece fundar, de alguma maneira, a lista das verdades triviais ou absolutas, transmitindo-lhes sua certeza imediata ou subjetiva. Todo o livro Sobre a certeza visa mostrar como tais proposições não podem, por razões lógico-gramaticais estritas, desempenhar o tranquilo papel filosófico fundacional que lhes atribui Moore. Trata-se da impossibilidade de fundar, nas "evidências" do senso-comum, uma filosofia realista e de mostrar, simultaneamente, que nenhuma evidência, nenhum contato privilegiado consigo mesmo podem, tampouco, ser chamados a amparar uma filosofia não realista, idealista, cética ou solipsista. No fundo, aponta Wittgenstein, são as mesmas razões que cancelam o sentido possível de realismo e de idealismo, que mostram que a aparente oposição entre essas metafísicas é meramente efeito de superfície, que ambas partilham do mesmo equívoco filosófico de base (PRADO Jr., 2004: 41).

Vejamos as cenas em que o filósofo tematiza a questão do saber e da certeza.

\section{Cena 8}

Contam-me, por exemplo, que alguém subiu a esta montanha há muitos anos. Informo-me sempre sobre a confiança que merece o narrador e se a montanha existia de fato há anos? Uma criança aprende que há informadores fidedignos e não fidedignos muito mais tarde do que aprende fatos que lhe são contados. Não aprende de modo algum que esta montanha existe há muito tempo: isto é, não se põe em questão isso ser assim. A bem dizer, engole essa conclusão juntamente com aquilo que aprende (UG, $\S 143$ - grifos nossos).

A criança aprende a acreditar num grande número de coisas. Isto é, aprende a atuar de acordo com essas convicções. Pouco a pouco se forma um sistema daquilo em que acredito e, nesse sistema, algumas coisas permanecem inabalavelmente firmes, enquanto algumas outras são mais ou menos susceptíveis de alteração. Aquilo que permanece firme não o é assim por ser intrinsecamente 
óbvio ou convincente; antes aquilo que o rodeia é que lhe dá consistência (UG, $\S 144$ - grifos nossos).

Em criança aprendemos fatos; por exemplo, que todos os seres humanos possuem um cérebro, e acreditamos neles. Acredito que existe uma ilha, a Austrália, com determinada forma, etc., etc.; acredito que tive bisavós, que as pessoas que se declararam meus pais eram realmente os meus pais, etc. Esta crença pode não ter sido nunca expressa; mesmo o pensamento de que era assim pode nunca ter sido pensado (UG, $§ 159$ - grifos nossos).

O aluno acredita nos professores e nos livros escolares (UG, §263).

Temos motivos para termos as nossas certezas. Elas se baseiam na relativa estabilidade do mundo que se constitui no "pano de fundo" onde calcamos nossa argumentação racional (Glock, 1988: 77). Se uma criança duvida imediatamente do que lhe é apresentado isto a impede de participar da prática epistêmica a ela apresentada, como já vimos em uma cena anterior.

Com essas cenas, Wittgenstein nos mostra mais de perto como facilmente confundimos Weltbild e Weltanschauung, o que nos leva a acreditarmos que encontramos um fundamento último para as proposições que estão na base do nosso Weltbild. Mais uma vez, é o hábito de pensar por dicotomias que nos leva a um equívoco de base com consequências, hoje sabemos, nefastas para a vida no planeta. Julgando ser a maior autoridade na área das epistemes, a forma de vida ocidental tem levado às últimas consequências suas "certezas". O animismo das formas de vida chamadas primitivas, tendo sido antes tratada com desdém, hoje começam a se mostrar não tão tolas:

Antes, ironizava-se a recusa, por parte dos índios, de conceder os predicados da humanidade a outros homens; agora se sublinha que eles estendem tais predicados muito além das fronteiras da espécie, em uma demonstraçãode sabedoria "ecosófica" [...] que devemos emular, tanto quanto permitam os limites de nosso objetivismo. Outrora, era preciso contestar a assimilação do pensamento selvagem ao animismo narcísico, estágio infantil do naturalismo, mostrando que o totemismo afirmava a distinção cognitiva entre o homem e a natureza (VIVEIROS DE CASTRO, 2011: 370 - grifo nosso).

É interessante observar que a filosofia wittgensteiniana, em sua capacidade de deslocamento de seu próprio tempo, antecipa-se a essas constatações que só agora a forma de vida ocidental se permite. Fazendo a distinção, digamos, gramatical, entre "saber" e "ter certeza", Wittgenstein aponta para um reconhecimento dos limites do pensamento, sobretudo no que tange à fundamentação de nossas "certezas". 


\section{Cena 9}

Que aconteceria se o aluno se recusasse a acreditar que esta montanha tem estado ali desde tempos imemoriáveis?

Diríamos que não tem razões fundamentadas para a sua suspeita.

Assim, a suspeita racional deve ter fundamentos?

Também poderíamos dizer «as pessoas sensatas acreditam nisto». (UG, §§322, 323 - grifos nossos)

O que importa a Wittgenstein ao trazer a questão da fundamentação em seus escritos tardios é justamente mostrar uma tensão instaurada entre universalismo objetivista e relativismo, mas não com a intenção de "superá-la em direção a uma síntese superior, mas para desqualificar simultaneamente os termos opostos" (PRADO Jr., 2004: 43) e com isso dar lugar à filosofia - uma filosofia perspectivista. As cenas 10 e 11, abaixo, nos permitem avançar na exploração de um perspectivismo wittgensteiniano.

\section{Cena 10:}

Uma criança que aprende a usar a palavra «árvore». Uma pessoa está com ela em frente da árvore e diz "Linda árvore!" Claramente, nenhuma dúvida quanto à existência da árvore se insinua no jogo de linguagem, mas pode dizer-se que a criança sabe "que existe uma árvore"? Tem de admitir-se que é verdade que "saber qualquer coisa" não implica pensar nisso - mas alguém que saiba qualquer coisa não tem de ser capaz de duvidar dela? E duvidar significa pensar (UG, §480 grifos nossos).

Nós dizemos: se uma criança adquiriu o domínio da linguagem - e daí das suas aplicações -, ela tem de saber o significado das palavras. Tem, por exemplo, de ser capaz de ligar o nome da respectiva cor a um objeto branco, preto, vermelho ou azul, sem ter qualquer dúvida (UG, $§ 522$ - grifos nossos)

\section{Cena 11:}

Mas será errado dizer "a criança que domina um jogo de linguagem tem de saber certas coisas"?

Se, em vez disso, se dissesse "tem de ser capaz de fazer certas coisas", isso seria um pleonasmo, contudo é exatamente isso que quero usar para refutar a primeira proposição. - Mas: "Uma criança adquire conhecimentos de história natural". Isso pressupõe que pode perguntar como se chama determinada planta.

A criança sabe como se chama uma certa coisa se puder responder corretamente à pergunta "Como se chama isso?"

Naturalmente, a criança que está exatamente aprendendo a falar ainda não se apropriou do conceito de chamar-se.

Poderá uma pessoa dizer de alguém que não possui esse conceito que ela sabe como se chama determinada coisas? 
A criança, em minha opinião, aprende a reagir de determinada maneira; e, ao reagir assim, ainda não sabe nada. $\mathrm{O}$ conhecimento só começa posteriormente (UG, $\S 534,535,536,537$ e 538 - grifos nossos).

Com essas cenas, Wittgenstein está colocando em questão os alicerces de nosso Weltbild e nos fazendo pensar sobre o que há em sua base, mitologia ou saber positivo (PRADO Jr., 2004:31). As regras que determinam os jogos de linguagem circunscrevem o quadro de referência que a criança adquire agindo como o adulto, e são essas referências que constroem seu discernimento entre verdadeiro ou falso, além de definirem suas certezas, emparelhando-as com a definição de verdade. Para Wittgenstein, o adulto demonstra a convicção como um estado de ausência de dúvida, chamando esse estado de "certeza subjetiva" (UG §194). O Weltbild de um indivíduo está diretamente ligado ao contexto de suas certezas (UG §162), pois algo foi ensinado como base, como o caso de um conjunto de informações consideradas certas, e dessa base consolidada, o indivíduo não possui dúvidas:

Em geral, considero verdade o que se encontra nos livros de estudo, de geografia, por exemplo. Por quê? Eu digo: todos esses fatos foram confirmados uma centena de vezes. Mas como sei isto? Que provas tenho? Tenho uma imagem do mundo. É verdadeira ou falsa? Sobretudo, é o substrato de todas as minhas perguntas e afirmações. As proposições que as descrevem não são todas igualmente sujeitas a verificação. (UG, §162)

Diante da ausência de fundamentação última, o que torna desaconselháveis uma hierarquia entre Weltbilder, Cavell defende, então, que se acolha uma variedade de compreensões. Dessa forma, Cavell nos possibilita introduzir, seguindo Wittgenstein, uma reflexão a respeito da noção de crença, principalmente quando questiona a ideia de convenção já pré-estabelecida para os sujeitos. Ao oferecer diferentes visões acerca da ideia de convenção que o indivíduo carrega, o autor baseia-se nas reações naturais da infância para confrontar o que o adulto, cujo aprendizado - aparentemente, ao menos - se estabilizou, tem como noções já edificadas. Cavell demonstra de que forma, para assimilar esse conteúdo como naturalizado, é preciso que o indivíduo concretize esse conceito dentro de si e não reflita mais sobre ele. Isso aparece quando o indivíduo, por exemplo, é confrontado por uma criança que lhe pergunte coisas como "Por que algumas pessoas são pobres e outras ricas?" ou "O que é Deus?" (CAVELL, 2012: 198). O indivíduo reflete sobre a consistência de sua 
argumentação, já que nota a própria dificuldade e fragilidade de suas colocações ao tentar formular uma justificativa que dê conta das explicações assumidas. Ele percebe, então, que essas conclusões acerca dos questionamentos do mundo não foram obtidas por ele, não cabe a ele esse "mérito".

Em função disso, Wittgenstein mostra que o indivíduo pode se dizer certo ou convicto de um conjunto de proposições a que ele foi exposto em toda sua vida, sem necessariamente possuir fundamentos ou argumentos que as justifiquem, como no $\$ 234$ de Da Certeza:

Acredito que tenha antepassados e que todos os seres humanos os têm. Acredito que há várias cidades e, em termos gerais, nos principais fatos da geografia e da história. Acredito que a Terra é um corpo na superfície do qual nos deslocamos e que não desaparece subitamente tal como qualquer outro corpo sólido: esta mesa, esta casa, esta árvore, etc.. Se pretendesse duvidar da existência da Terra muito antes do meu nascimento, teria de duvidar de todas as espécies de coisas que são ponto assente para mim.

Diante dessas evidências, sempre cabe nos perguntarmos em quantas coisas acreditamos por que simplesmente nunca nos questionamos sobre elas. E retornamos às reflexões de Wittgenstein sobre a filosofia, sobre não adiantar estudar filosofia se ela não nos ajuda a pensar nas questões do cotidiano. Podemos dizer que Wittgenstein usa frequentemente uma mesma estratégia para convidar a pensar: mostrar. De preferência mostrar o que está tão próximo que não conseguimos ver.

\section{3}

\section{Alteridade e perspectivismo}

Com pessoas que tivessem todas os mesmos traços fisionômicos, já não saberíamos como lidar com elas.

L. Wittgenstein

Em Perloff, a nosso ver, encontramos uma insistência em evidenciar o caráter perspectivo na filosofia wittgensteiniana. Este caráter é prestigiado de maneira inequívoca quando a autora compara o "método para ir em frente" de Wittgenstein à produção de arte. Além disso, sua leitura se torna ainda mais pertinente ao que aqui investigamos se aceitamos, com Deleuze, que, em certo sentido, "à sua maneira, a arte diz o que as crianças dizem" (1997: 78), ou ainda 
em outra formulação mais aproximada a Agamben, concordarmos que a arte, como as crianças, guarda a capacidade de fazer experimentos (com a linguagem, com a vida) o que se assemelha à atividade de filosofar em Wittgenstein, substituindo toda teoria por uma "investigação gramatical".

\begin{abstract}
"Desconfiar da gramática", Wittgenstein já havia postulado em Notes on Logic, "é o primeiro requisito para se filosofar" (NBK 106). E, por extensão, também para se fazer poesia. Pois, embora Wittgenstein fosse argumentar, depois, que a gramática é precisamente a chave para se compreender uma determinada proposição, que não existe nenhuma essência acima e além de uma estrutura gramatical específica, deve-se, apesar disso, "desconfiar" da gramática, no sentido de interrogá-la tão rigorosamente quanto possível. É nesse sentido que se pode dizer que a gramática substitui a teoria. (PERLOFF, 2008: 38-39)
\end{abstract}

\title{
Cena 12
}

Todas as questões aqui consideradas ligam-se ao seguinte problema: suponham que tinham ensinado alguém a escrever séries de números segundo regras do gênero: escreve sempre um número $n$ maior que o anterior. (Esta regra é abreviada para "Acrescenta $n$ ".) Os números serão, neste jogo, grupos de traços I, II, III, etc. Aquilo a que chamo ensinar este jogo consiste, evidentemente, em fornecer explicações gerais e dar exemplos. Estes exemplos são extraídos da série de, por exemplo, 1 a 85. Damos agora ao aluno a ordem "Acrescentar 1". Passado algum tempo, constatamos que, depois de ultrapassado o 100, ele fez o que chamaríamos acrescentar 2; depois de ultrapassado 300, ele faz o que chamaríamos acrescentar 3. Chamamo-lo por causa disto e dizemo-lhe: "Não te disse para acrescentares sempre 1 ? Observa o que fizeste antes de chegares a 100!" Suponham que o aluno dizia apontando para os números 102, 104, etc., "Pois bem, não foi isso que eu fiz aqui? Pensava que era isto que você queria que fizesse.". - Conforme constatam, em nada adiantaria aqui dizer "Mas não vês que... ?", chamando-lhe a atenção de novo para as regras e os exemplos que lhe tínhamos dado. Poderíamos, num caso deste tipo, dizer que esta pessoa compreende naturalmente (interpreta) a regra (e os exemplos) que lhe demos, da mesma maneira que nós compreendemos a regra (e os exemplos) que nos diriam: "Acrescenta 1 até 100, depois2 até 200, etc." (BB, Parte II, §5 - grifos nossos).

A possibilidade de abrigar uma nova percepção na aplicação de uma regra supõe não exatamente uma tolerância para o erro, mas a capacidade de olhar para a nova percepção de modo a manter (e não anular) a alteridade. Cavell também levanta questionamentos sobre o propósito das convenções, a quem elas servem e quais seus objetivos. Pensar sobre isso seria uma possibilidade de reação do indivíduo quando confrontado acerca daquilo que tomou para si como verdade instituída - reação considerada por Cavell como a mais apropriada para esta situação. Numa reflexão crítica, nota-se que não é, no mais das vezes, inconveniente questionar uma convenção - o que, contraditoriamente, encerra o caráter natural dessa assimilação. Contudo, no momento em que o indivíduo 
constata a convenção naturalizada, esse processo se inverte, tornando-se descabido dar continuidade a uma convenção sem questioná-la - isso no caso de o indivíduo se propor a análise em vez de manter a acomodação com o próprio desengano, o que, para Cavell, é hipocrisia, afinal, esse sujeito despertou para o que seja uma convenção em seus saberes, mas apenas prefere, por acomodação, ignorá-la (CAVELL, 2012: 182- 187).

Questionar uma convenção significa, muitas vezes, desistir do caminho que se apresenta, como o próprio Wittgenstein fez ao romper com o paradigma da linguagem como representação. Rompimento que não significou, aliás, ausência de produção, ao contrário, o que se pode ver é um alargamento da ideia de razão que aparece na busca por um logos estético ou um logos prático no lebensform do Wittgenstein maduro (Prado Jr., 2004: 200-201), recorrendo a diversos textos que, em suma, põem em discussão a conhecida (e antiga) provocação de Protágoras " $\mathrm{O}$ homem é a medida de todas as coisas - das que são enquanto são; das que não são enquanto não são". Prado Jr., como Perloff, destaca, na guerra entre relativismo e universalismo, a ideia de filosofia como construção ou, em suas palavras, a ideia do "privilégio da ideia de produção (poíesis) sobre a de descoberta (alétheia) da verdade" (p. 119 e p. 205). A filosofia como construção, antes de mais nada, precisa reconhecer que "sempre é verdade que a tarefa da filosofia é a da crítica como delimitação do dizível" e que "sempre é verdade que o essencial está para além do dizível" (PRADO Jr., 2004: 127), ou seja, a possibilidade de fazer filosofia nasce de uma impossibilidade que é inerente a esse fazer. Tal paradoxo exige do filósofo, no mínimo, uma atitude de modéstia e humildade, atitude que não implica, contudo, submissão, mas antes independência de pensamento. $\mathrm{O}$ filósofo deverá, em todo caso, construir seu pensamento de forma maximamente sensível à irredutível pluralidade dos Weltbilder, à contingência não apenas do seu pensamento mas da consistência do seu próprio mundo, da sua própria vida. $\mathrm{O}$ que Prado Jr. parece sublinhar com suas reflexões aqui citadas é que o sentido da terapia filosófica proposta por Wittgenstein é o de compreender a alteridade, e não o de anulá-la pela via da persuasão.

Cabe aqui retomar Viveiros de Castro quando conta sua motivação inicial nos estudos etnológicos. Discorre sobre como começou a entender as cosmologias ameríndias a partir de uma recusa dos dois paradigmas que orientavam a etnologia brasileira quando iniciou os estudos com os chamados "povos primitivos": 
Meu problema teórico era entender aquelas sociedades em seus próprios termos, isto é (e só pode ser),em relação ás suas próprias relações: (...) Acho que existem dois grandes paradigmas que orientam a etnologia brasileira. De um lado, a imagem antropológica de "sociedade primitiva"; de outro, a tradição derivada de uma "Teoria do Brasil" (...): o foco é o Brasil, os índios são interessantes $\mathrm{em}$ relação ao Brasil, na medida em que são parte do Brasil. Nada a objetar, esta sociologia do Brasil indígena é uma empresa altamente respeitável e resultou em trabalhos extremamente importantes. Mas esta não era a minha. A minha era a mal-chamada "sociedade primitiva", meu foco eram as sociedades indígenas, não o Brasil: o que me interessava eram as sociologias indígenas (VIVEIROS DE CASTRO, 2011: 475-76).

De certo modo, é possível dizer que, à maneira dos xamãs, em sua recusa à objetividade que de antemão se oferecia nos paradigmas clássicos, o antropólogo buscou subjetivar os povos indígenas para conhecê-los em sua potência como alteridade. Ilustra assim, mais uma vez, a atitude perspectivista que reconhecemos preconizada também nos escritos wittgensteinianos.

\section{Cena 13:}

Como se ensina uma criança (em cálculo, por exemplo): "agora junte esses pontos!" ou "agora eles formam um conjunto"? Evidentemente, "juntar" e "formar um conjunto", originalmente devem ter tido para ela uma significação [diferente?] do que a de ver algo deste ou daquele modo. - E isto é uma observação sobre conceitos, não sobre métodos de ensino. (PU, p. 189)

Como Wittgenstein adverte, é preciso lê-lo demoradamente, ruminando cada palavra:

Por vezes, uma frase só se pode compreender se for lida no tempo certo. As minhas frases são todas para ler devagar (VB, p. 88).

É preciso ler a pequena observação ao final do parágrafo que ilustra a cena 13: "E isto é uma observação sobre conceitos, não sobre métodos de ensino". É em geral fácil concordar que as crianças demonstram capacidade aguçada para as artes, para o improviso, para o "ver como" que exige delas aguçada percepção de aspectos variados de uma mesma coisa. Mas aqui, trata-se, parece-nos, de mostrar diferentes aspectos de um mesmo conceito e diferentes maneiras de respeitar a alteridade ao procurar ouvir o modo como ela percebe o conceito explicado. E lendo Wittgenstein segundo seu próprio conselho, recuamos até o $§ 97$ das Investigações para ouvir a seguinte explicação: 
Estamos na ilusão de que o especial, o profundo, o essencial (para nós) de nossa investigação residiria no próprio fato de que ela tenta compreender a essência incomparável da linguagem. Isto é, a ordem que existe entre os conceitos de frase, palavra, conclusão, verdade, experiência etc. Esta ordem é uma super ordem entre - por assim dizer - superconceitos. Enquanto as palavras "linguagem", "experiência", "mundo", se têm um emprego, devem ter um tão humilde quanto às palavras "mesa", "lâmpada", "porta".

Em cenas de ensino, sejam elas escolares ou não, parece comum que o professor dê às suas palavras uma gravidade e prestígio descabidos, envolvendoas em um mistério que mais obstrui a comunicação que o contrário, quando, na verdade, necessita-se de clareza. O pressuposto, quando se pensa que há uma essência que as palavras representam, é que essa essência exista e que, nesse caso, o aprendiz a atinja. A pergunta de Wittgenstein para nós é: essa essência existe? E sua resposta, já conhecemos, é “Não!”. Assim, se por um lado Wittgesntein não pretende nos ensinar nenhuma técnica de ensino, se não pretende divulgar nenhum método de ensino, por outro lado, faz um convite para que nos demoremos na consideração à diversidade de interpretações possíveis e, ao mesmo tempo, faz um chamado para a percepção de nossas palavras em toda sua "humildade", trazendoas para o trabalho que efetivamente realizam, o que se traduz, sobretudo, por uma consideração e manutenção da alteridade.

\section{Cena 14}

Poder-se-ia também imaginar tal ensino em uma espécie de aritmética. As crianças podem então, cada uma a seu modo, calcular, desde que ouçam apenas a voz interior e sigam. Este cálculo seria como uma composição.

Mas não poderíamos também calcular, como calculamos (todos de acordo etc.), e, contudo, a cada passo, ter a impressão de ser dirigido pela regra como que por um passe de mágica, e admirar-nos talvez do fato que concordemos? (Agradecendo talvez à divindade por esta concordância.)

Crianças jogam esse jogo. Elas dizem, por exemplo, que uma caixa é agora uma casa; e ela é, desde então, inteiramente considerada como uma casa. Uma invenção tecida nela.

E a criança vê a caixa como casa?

"Ela esquece inteiramente que é uma caixa; para ela é de fato uma casa." (Há determinados indícios disso.) Não seria então correto dizer também que ela a vê como casa?

E quem pudesse jogar assim, e exclamasse numa situação determinada, com uma expressão peculiar: "Agora é uma casa!" - daria expressão à revelação do aspecto. Se eu ouvisse alguém falar sobre a cabeça L-P [lebre-pato], e agora, de certo modo, sobre a expressão peculiar do rosto da lebre, diria que ele vê a figura agora como lebre.

A expressão da voz e do gesto é, porém, a mesma, como se o objeto tivesse mudado e finalmente se tornado isto ou aquilo. (PU, pp. 178-188) 
A importância dada por Wittgenstein à percepção do aspecto não se reduz às conhecidas figuras da lebre-pato ou pato-lebre. Há também uma aproximação dessa figura àquilo que as palavras podem fazer conosco a partir de sua "fisionomia familiar": associam-se com outras palavras, situações, experiências etc e assim estabelecem conexões (GLOCK, 1998: 54), dando à significação uma sucessão de infinitas possibilidades. Wittgenstein discorre sobre a "cegueira para o aspecto" e compara-a à ausência de "ouvido musical. A cegueira para o aspecto é, vista assim, uma quase mutilação, pois retira de nós a potência criadora.

A cena acima, somada à ideia de percepção do aspecto, pode, assim, ser associada ao perspectivismo ameríndio:

Todo ser a que se atribui um ponto de vista será então sujeito, espírito. Ou melhor, ali onde estiver o ponto de vista, também estará a posição de sujeito. Enquanto nossa cosmologia construcionista pode ser resumida na fórmula saussureana: $o$ ponto de vista cria o objeto - o sujeito sendo a condição originária fixa de onde emana o ponto de vista -, o perspectivismo ameríndio procede segundo o princípio de que o ponto de vista cria o sujeito; será sujeito quem se encontrar ativado ou agenciado pelo ponto de vista. (VIVEIROS DE CASTRO, 2011: 373).

O filósofo nos deixa agora a possibilidade de pensar a educação que tanto pode despertar para múltiplas percepções (musicais, por exemplo) como pode adormecê-las de modo que, assim como na conhecida figura da lebre-pato, alguém só possa ver a lebre. Ou só o pato. Também as palavras, com seu "rosto peculiar" são capazes de provocar ressonâncias específicas naquele que as pronuncia. Isso mostra a força poética das palavras: essa ressonância se produz no corpo de quem fala. Deixar de estar preso a uma figura libera para a tarefa de filosofar: "Uma figura nos mantinha presos" (PU, §115). Nos dizeres de Gebauer:

Se a falta de precisão num uso linguístico incontrolado é uma fonte de sofrimento com a linguagem, a outra é a fixação num aspecto unitário provocada pela busca da precisão. [...] Nas investigações filosóficas, Wittgenstein trabalha na anulação da coerção originária de uma concepção da linguagem totalmente controlada. Com suas reflexões a partir de 1947, ele desenvolve uma nova mobilidade no trato com a linguagem, que não é restringida por uma ordem de silêncio (GEBAUER: 2013: 185-86).

Podemos dizer, em espírito cavelliano, que, se a filosofia é a “educação dos adultos", é porque talvez seja filosoficamente mais instrutiva do que a separação entre o adulto e a criança da sua unidade fundamental. 


\section{Conclusões} “Ordem”, permitam-me explicar, significa monotonia, regularidade, repetição e
previsibilidade. (Z. Bauman)

Na filosofia madura de Wittgenstein há pouquíssimas soluções e isso parece ter ocorrido de maneira deliberada, não para abrigar o relativismo, mas para deixar ao leitor o espaço ao livre exercício do pensamento, revelando uma pluralidade epistêmica que dá lugar às aporias. É ao leitor, no fim das contas, que cabe a tarefa de pensar o que significa um "jogo de linguagem", e uma "forma de vida", por exemplo. O encontro com a antropologia, ao que parece, tornou visível os acordos que fazemos em nossas formas de vida e dispensou os conceitos dogmáticos que são necessários quando entendemos a linguagem como representação do mundo. No parágrafo 67 de Da certeza Wittgenstein afirma que:

a fundamentação, a justificação da evidência tem um fim - mas o fim não é o fato de certas proposições se nos apresentarem como sendo verdadeiras, isto é, não se trata de uma espécie de ver da nossa parte; é o nosso atuar que está no fundo do jogo da linguagem (UG, § 67).

A concepção wittgensteiniana pensa a linguagem em seu pragmatismo, isto é, a linguagem não está restrita a uma forma lógica de proposição, ela não cabe em uma formalização. Os jogos de linguagem, portanto, em conjunto com suas regras, obedecem às semelhanças de família, mas sem haver uma estrutura para dispor seus elementos. Os jogos de linguagem estão envolvidos com sua pluralidade e podem ser contemplados por meio das formas de vida, por meio de uma trama tecida pelas significações, sem uma objetividade única, o que nos leva a pensar que embora a visão wittgensteiniana sobre a linguagem não considere a subjetividade da mesma maneira que a cosmovisão ameríndia, ela se diferencia do objetivismo ao considerar as formas de vida como próprias de certa pessoa ou cultura, ao considerar os modos sui generis de pensamento. $\mathrm{O}$ exame das cenas de alteridade revelam aquilo que há de mais intenso na filosofia de Wittgenstein e que a revela perspectivista: a impossibilidade de reduzir a linguagem ao que quer que seja, a impossibilidade de torná-la um objeto a ser posto sob lentes microscópicas através das quais poderemos finalmente conhecê-la e apaziguá-la em sua potência inovadora. Nesse sentido, Prado Jr. sublinha o valor da atividade 
crítica do filósofo que é "essencialmente algo como a exploração da alteridade, numa direção diferente daquela seguida pelo missionário em sua tarefa persuasiva" e em seguida pergunta: "Compreender um outro sistema de regras não seria compreender a loucura?" (PRADO Jr., 2004: 55).

A capacidade de abrigar as aporias seria, como se disse, uma das principais características da filosofia wittgensteiniana. Ali onde se procura uma resposta única, um caminho, uma solução, Wittgenstein desconfia e investiga, sem, no entanto, preocupar-se em encontrar "a" resposta. Essa investigação, em seus escritos da maturidade, parte sempre daquilo que pode, efetivamente, ser visto: a ação em determinado contexto. Divorciando-se completamente das explicações que se apoiam na possibilidade de um significado "mental" que, para comunicar, pressupõe sempre uma essência da coisa que é para nós inapreensível, sua percepção é a de que os significados são construções públicas tecidas em um acordo feito entre os indivíduos que compartilham uma forma de vida. Sua crítica à linguagem da metafísica ocidental em seu equívoco de base, crítica aliás que Prado Jr. descreve como "uma guerra filosófica antiga contra toda forma de fundacionismo" (PRADO Jr., 2004: 25), é, dessa forma, uma concomitante “oposição ao espírito dominante na civilização tecno-científica contemporânea" (PRADO Jr., 2004: 27). O combate se justifica pelo fato de que esse espírito, em última análise, cristalizou-se, por assim dizer, sob o pano de fundo das partições dicotômicas possibilitadas, antes de mais nada, por nossas ilusões de certeza advindas de uma gramática, ou, nos dizeres de Agamben, no "oblívio da diferença entre língua (semiótico) e fala (semântico)" (AGAMBEN, 2005: 71), esquecimento que permite fundar a metafísica ocidental.

A cegueira para o aspecto parece ser um dos efeitos colaterais herdado das nossas partições ontológicas, cegueira a ser igualmente combatida por Wittgenstein, pois dela derivamos, em última instância, o desejo de anulação da alteridade. Todo dilema, seja na visão universalista, seja na visão relativista, encontrará um ponto de vista verdadeiro. A grande diferença entre as duas correntes mais largamente difundidas seria a recomendada tolerância do relativismo com os pontos de vista divergentes daquele que é o mais recomendado (para a forma de vida ocidental, o científico, em última análise). A divergência entre o relativismo e as filosofias perspectivistas como a encontrada em Nietzsche, em Deleuze e em Wittgenstein, como vimos, reside justamente na 
possibilidade de diálogo entre as variadas cosmologias, já que o horizonte de certezas ou um fundamento último seriam simplesmente impensáveis. Pensar é navegar no caos, em total ausência de horizontes. Não se trata, portanto de tolerar a verdade do outro (caso do relativismo), mas de admitir infinitas interpretações, infinitos mundos possíveis.

Esses infinitos mundos possíveis podem apenas ser pensados do lugar descrito por Wittgenstein como o "caos arcaico":

Através da filosofia devemos mergulhar no caos arcaico e lá sentirmo-nos bem (VB, p. 98).

Segundo Prado Jr.(2004: 154), voz a qual recorremos ainda uma vez, a expressão “caos" na linguagem de Wittgenstein é "uma espécie de 'experiência' não amparada por um sistema de regras". Em outras palavras é "a loucura em sua oposição tanto ao erro como à ilusão" (Idem, p. 155). Tal ausência de regras é a condição essencial para a experiência que apenas pode ter lugar na infância, e justamente porque aí se separam experiência e conhecimento ${ }^{26}$. A ideia de uma experiência separada do conhecimento é para nós estranha, uma vez que a nossa forma de vida elegeu, antes, a certeza, o que significa dizer: o fim da infância.

Em Wittgenstein são recorrentes os avisos para que não nos deixemos iludir pela gramática, essa ilusão de certeza que iniciou, por assim dizer, a moderna ideia de progresso, ideia, como vimos, tão amplamente combatida pelo filósofo vienense. Poderíamos dizer que esses avisos são um convite para mantermos o nosso pensamento em toda sua força e sanidade infantil, guardando, assim, sua fertilidade, e abrindo exemplarmente o espaço para a alteridade, o único espaço onde a arte, em toda a sua potência criadora, pode sobreviver.

Se as cenas de alteridade adulto $v s$ criança que aparecem nos escritos mais tardios de Wittgenstein podem ser verdadeiros alertas sobre nossas práticas esterilizantes em educação, podem, igualmente, lançar luz sobre aspectos importantes dessa filosofia que, ao romper com o paradigma tradicional, aproxima-se da antropologia e discute a linguagem como parte de nossas práticas. Desligando-se completamente da possibilidade de teorizar a linguagem, o filósofo

${ }^{26}$ Ver, a esse respeito, "Infância e história: destruição da experiência e origem da história" em Agamben, [1978] 2014. 
procura na ação, e na vida, a relação entre as palavras e seus significados, fazendo uso então das ideias de jogos de linguagem e forma de vida, mostrando as relações entre o ensino, a aprendizagem e as certezas que dão sustentação às nossas práticas.

O antropólogo Viveiros de Castro, cuja atitude frente à forma tradicional de encarar o pensamento selvagem é igualmente revolucionária, traz o pensamento indígena em seus próprios termos, não mais subordinado ao pensamento ocidental, mas alçado à condição de interlocutor. Nesse novo enfoque, os povos indígenas já não devem ser vistos como o exótico não-ocidental, um elemento a ser dissecado, sendo útil naquilo que tem a ser estudado objetivamente, mero objeto enquadrado em nossa moldura do conhecimento.

Como vimos, a cosmologia ameríndia abriga, da mesma forma que as filosofias perspectivistas, uma multiplicidade de interpretações na própria recusa da ideia de visão de mundo. Há, diz-nos o antropólogo, mundos de visão e não visões de mundo, pois é o mundo que muda de acordo com a subjetividade que vê esse mundo. Se para os povos indígenas conhecer é subjetivar, a negociação e diplomacia entre mundos se torna uma necessidade. Nesse mundo em que as dicotomias estão desconvidadas, não há objeto do conhecimento. Há seres e há mundos.

Este parece ser um ponto de convergência entre o pensamento ameríndio que conhecemos via Viveiros de Castro e o pensamento de Wittgenstein: a "descolonização" do pensamento, para ficarmos com as palavras de Viveiros de Castro. $\mathrm{Ou}$, como aprendemos com Wittgenstein e Agamben, na experiência possível que é a infância. Se Wittgenstein implode a metafísica da gramática ocidental e deixa descobertos os falhos argumentos que buscam uma fundamentação que ampare a razão do ego cogito, Viveiros de Castro propõe igualmente, para os estudos antropológicos, a implosão da partição sujeito/objeto do conhecimento, onde o objeto é sempre o outro a ser sistematicamente reduzido pelas lentes da objetivação. Essa mudança radical tiraria a antropologia da posição de tradutora (equivocada) de uma forma de vida vista sob o pano de fundo da forma de vida do outro. Alçando diferentes formas de vida à posição de diálogo, está convidada, como em Wittgenstein, a necessária visão sinóptica sem a qual não se pode assegurar a aceitação de um entreconhecimento comparativo. Tanto em Wittgenstein quanto em Viveiros de Castro, solicita-se a difícil capacidade de 
ver-se a si mesmo e ao outro estando de fora, o que significa dizer, antes de mais nada, estar em pé de igualdade: somos tão loucos, ou tão sãos, quanto esses índios são loucos, ou sãos. 
Mapeamento do Corpus

SELEÇÃO CENAS WITT A PARTIR DO CORPUS DE PESQUISA

1. JOGOS DE LINGUAGEM E FORMA DE VIDA:

Philosophical Remarks: $33 ; \S 102 ;$ XIV.

Philosophical Grammar: §24; §25; §26; §32; §69; §75; §103

The Brown Book: §I; §5; §30; §56; §64, §66.

Philosophical Investigations: §6; §9; §27; §137; §282; §304; XI.

Remarks On The Philosophy Of Psychology - Vol I: §142; §145; §163; §239;

§245; §375; §412; §479; §478; §706; §853; §940; §945.

Remarks On The Philosophy Of Psychology - Vol II: §15; §40; §41; §42; §55; §128; §139; §171; §198; §241; §315; §330; §535.

Last Writings On The Philosophy Of Psychology - Vol I: §760; §800; §866; §868; §871; §872; §873; §899; §939; §941; §942.

Last Writings On The Philosophy Of Psychology - Vol II: §75; §319; §339. §343; §344 I, 868, 939; III: MS 171

On Certainty: §165; §182; §233; §283; §374; §450; §476; §477; §480; §522; §527; §529; §534; §536; §543; §545; §547; §548; ; §581; §566.

Remarks On The Foundations Of Mathematics: §18; §22; §37; Part. VI §9; § 54; §144; Part. V §5. § 31. Part. VII. § 24

Zettel: §34; §42; §324; §383; §587; §412; §594; §646; §703.

\section{CRENÇA E CERTEZA:}

Philosophical Remarks: $§ 133$

Philosophical Grammar: §67; Part II, § 25.

The Brown Book: $\$ 4 ; \S 126$.

Remarks On The Foundations Of Mathematics: §14; §50; §53; §61; §78; §82. 
Zettel: $\S 409 ; \S 411 ; \S 413 ; \S 414 ; \S 422$.

Philosophical Investigations: $§ 194, \S 241, \mathrm{XI}$

Remarks On The Philosophy Of Psychology - Vol I: §93; §360; §411; §977.

Remarks On The Philosophy Of Psychology - Vol II: $§ 536$.

Last Writings On The Philosophy Of Psychology - Vol I: §237; §472; §477;

$\S 572$.

On Certainty: §106. § 107. § 143. §144. §159. §160. §167. § 290. § 478. § 527. § 529. § 545 .

\section{PERSPECTIVISMO:}

Philosophical Remarks: $§ 5$

Philosophical Grammar: $§ 26 ; \S 28 ; \S 66 ; \S 75$.

The Blue Book: Page 26

The Brown Book: $\S 32 . \S 52$.

Remarks On The Foundations Of Mathematics: $§ 9 . \S 11 . \S 37 . \S 61$.

Zettel: $§ 469$.

Philosophical Investigations: §5; §9; §32; XI §195; §257; §282.

Remarks On The Philosophy Of Psychology - Vol I: §65. § 245. §346. §413. §425. §426. §520. §541. §979. §1105.

Remarks On The Philosophy Of Psychology - Vol II: §75; §198; §338. I, 939940, 946.

Last Writings On The Philosophy Of Psychology -Vol I: §73. §473; §572; $\S 700 ; \S 737 ; \S 741 ; \S 795$.

On Certainty:. §107; §144; §159; §167; §472; §547.

Remarks On Colour: §122; §240. 


\section{Referências}

\section{OBRAS DE WITTGENSTEIN:}

Philosophical Remarks [1920-30]. R. Rhees (ed.), tr. R. Hargreaves, R. White, Oxford: Blackwell, 1975. [Em português: Observações filosóficas. Tr. (do inglês) A. Sobral e M. S. Gonçalves, São Paulo: Edições Loyola, 2005.]

The Blue and Brown Books: Preliminary Studies for the "Philosophical Investigations". New York: Harper \& Row, 1965. [Em português: O livro azul. Tr. Jorge Mendes, Lisboa: Edições 70, 1992. / O livro castanho. Tr. Jorge Marques Lisboa: Edições 70, 1992.]

Remarks on the Foundations of Mathematics [1937-44]. H. von Wright, G. E. M. Anscombe (eds.), tr. G. E. M. Anscombe, Oxford: Blackwell, 1978.

Vermischte Bemerkungen / Culture and value. [German-English parallel text]. G. Von Wright in collaboration with Nyman, tr. Peter Winch. Oxford: Basil Blackwell, 1989. [Em português: Cultura e valor. Tr. Jorge Marques Lisboa: Edições 70, 1996.]

Philosophical Grammar. R. Rhees (ed.), tr. Anthony Kenny, Oxford: Blackwell, 1974. [Em português: Gramática filosófica.Tr. (do inglês) Luiz Carlos Borges, São Paulo: Edições Loyola, 2003.]

Bemerkungen über Frazers Golden Bough / Remarks on Frazer's golden Bough. In [PO], pp. 115-155. [Em português: Observações sobre o Ramo de Ouro de Frazer. Tr. e notas João José R. L. Almeida. Adverbum, vol 2/2, 2007, pp. 186-231. Disponível em: http://www.psicanaliseefilosofia.com.br/adverbum/Vol2_2/observacoes_ramo_de _ouro.pdf, acesso em 05/08/2014]

Remarks on the Foundations of Mathematics [1937-44]. H. von Wright, G. E. M. Anscombe (eds.), tr. G. E. M. Anscombe, Oxford: Blackwell, 1978.

Zettel. [1945-8, German-English parallel text] G. H. von Wright e G. E. M. Anscombe (eds.)., tr. G. E. M. Anscombe. Berkeley e Los Angeles: University of California Press, 1970. [Em português: Fichas/ Zettel. Tr. Ana B. da Costa, Lisboa: Edições 70, 1989. 
Philosophische Untersuchungen / Philosophical Investigations: The German Text, with a Revised English Translation 50th Anniversary Commemorative Edition, tr. G. E. M. Anscombe. Oxford: Blackwell, 2001. [Em português: Investigações Filosóficas. Tr. José Carlos Bruni, São Paulo: Editora Nova Cultural, 1999.]

Bemerkungen über die Philosophie der Psychologie / Remarks on the Philosophy of Psychology, vol. I. [1945-7, German-English parallel text]. G. H. von Wright, G. E. M. Anscombe (eds.), tr. G. E. M. Anscombe, Oxford: Blackwell, 1980. [Em português: Observações sobre a filosofia da psicologia. Tr. Ricardo Hermann P. Machado, São Paulo: Idéias e Letras, 2008.]

Bemerkungen über die Philosophie der Psychologie / Remarks on the Philosophy of Psychology, vol. II. [1948, German-English parallel text]. G. H. von Wright, H. Nyman (eds.), tr. C. G. Luckhardt, M. A. E. Aue, Oxford: Blackwell, 1980. [Em português: idem vol. I, acima]

Last Writings on the Philosophy of Psychology. Edited by G. H. von Wright and Heikki Nyman. Translated by C. G. Luckhardt and Maximilian A. E. Aue. Vol. I. Oxford: Basil Blackwell, 1982. [Em português: Últimos Escritos sobre a Filosofia da Psicologia, Tradução de João Tiago Proença, António Marques e Nuno Venturinha Lisboa: Gulbenkian, 2007, 372 pp]

Last Writings on the Philosophy of Psychology. Edited by G. H. von Wright and Heikki Nyman. Translated by C. G. Luckhardt and Maximilian A. E. Aue. Vol. II. Oxford: Basil Blackwell, 1992.

Über Gewissheit / On Certainty. [1951, German-English parallel text] G. H. von Wright, G. E. M. Anscombe (eds.)., tr. Denis Paul, G. E. M. Anscombe, New York: Harper \& Row, 1972. [Em português: Da certeza. Tr. de Maria E. Costa, Lisboa: Edições 70, 2000.]

Bemerkungen über die Farben / Remarks on Colour [1951, German-English parallel text]. G. E. M. Anscombe (ed.), tr. L. L. McAlister, M. Schättle, Oxford: Blackwell, 1980. [Em português: Anotações sobre as cores. Tradução F. Nogueira e M. J. Freitas. Lisboa: Edições 70, 1987.]

\section{OUTRAS OBRAS:}

AGAMBEN, G. Infância e História. (Trad. Henrique Burigo). Belo Horizonte: Editora UFMG, 2014.

BAKER, Gordon P.; HACKER, P.M.S. Wittgenstein: understanding and meaning. Vol. 1. 2nd, extensively rev. ed. Chicago: University of Chicago Press, 2005.

Wittgenstein: rules, grammar and necessity. Volume 2 of an Analytical Commentary on the Philosophical Investigations. Oxford: Blackwell Publishers, 1985 
Wittgenstein: meaning and mind. An analytical commentary on the Philosophical Investigations; v. 3. Cambridge: Basil Blackwell, 1990.

BOUVERESSE, Jacques. L'animal cérémoniel: Wittgenstein et l'anthropologie. In: Actes de la recherche em Sciences sociales. Vol.16, septembre, 1977. Questions de politique. pp. 43-54. Disponível em: < http://www.persee.fr/web/revues/home/prescript/article/arss_03355322_1977_num_16_1_2567>. Acesso em 13 fev 2015.

CARVALHO, Marcelo. Mentira, erro, ilusão, falsidade. Sobre Nietzsche e Wittgenstein. Cadernos Nietzsche, n³3. São Paulo, 2013. Disponível em: $<$ http://www.scielo.br/scielo.php?pid=S2316-

82422013000200009\&script=sci_arttext $>$. Acesso em: 05 mai. 2014.

Imagem e dissolução entre as Investigações e Da certeza. 2007. Tese (Doutorado em Filosofia) - Universidade Federal de São Paulo, São Paulo, 2007. Disponível em <http://www.teses.usp.br/teses/disponiveis/8/8133/tde-27112009115332/pt-br.php> Acesso em: 07 jul. 2014.

CORNELLI, Gabriele e CARVALHO, Marcelo (Orgs). Filosofia: conhecimento e linguagem. Central de Texto, Cuiabá, 2013. Online - disponível em: < https://www.academia.edu/10773123/Filosofia_conhecimento_e_linguagem__vol._4._Cuiab\%C3\%A1_Universidade_Aberta_do_Brasil_Central_de_Texto_20 13_v.1._p.176> Acesso em $15 \mathrm{dez} 2015$.

CASTRO, Eduardo Viveiros de. Os pronomes cosmológicos e o perspectivismo ameríndio. Mana, Rio de Janeiro, V. 2, n. 2, p. 115-144, out. 1996.

Estrutura ou Sentimento: A Relação com o Animal na Amazônia. Mana, vol. 4, n. 1, pp. 23-45, 1998.

A inconstância da alma selvagem e outros ensaios de antropologia. Cosac \& Naify, São Paulo, 2011.

$2002 b$.

O nativo relativo. Mana, Rio de Janeiro, V. 8, n. 1, p. 113-148, abr

; SZTUTMAN, Renato (org.). Eduardo Viveiros de Castro. Coleção Encontros. Rio de Janeiro: Azougue Editorial, 2008.

CAVELL, Stanley. The Claim of Reason: Wittgenstein, skepticism, morality and tragedy. New York: Oxford University Press, 1979.

Esta América nova, ainda inabordável. Trad. Heloisa Toller Gomes.

São Paulo: Ed. 34, 1997.

"The normal and the natural". In Mulhall, Stephen (org.) A Cavell Reader. Oxford: Balckwell, pp. 31-45, 1996. [Texto originalmente publicado em The Calim of Reason: Wittgenstein, Skepticism, Morality, and Tragedy. Oxford: Calrendon Press, 1979]. 
DELEUZE, Gilles. A dobra: Leibniz e o barroco. Tradução Luiz B.L. Orlandi, Campinas, SP: Papirus, 2007.

1997.

Crítica e clínica. Tradução de Peter Pál Pelbart. São Paulo: Editora 34,

Conversações. Trad. de Peter Pál Pelbart. São Paulo: Editora 34, 2013.

Nietzsche. Trad. de Alberto Campos. Lisboa: Edições70, 2014.

DELEUZE, G. \& GUATTARI, F.. O que é a filosofia? Trad. Bento Prado Jr. e Alberto Alonso Muñoz. São Paulo: Editora 34, 2005.

FERREIRA, Maristela da Silva; MARTINS, Helena Franco. Pontifícia Universidade Católica do Rio de Janeiro - Departamento de Letras. A palavra em construção : um estudo wittgensteiniano sobre a identidade das unidades linguísticas. 2010. Tese (Doutorado) - Pontifícia Universidade Católica do Rio de Janeiro, Departamento de Letras, 2010. Disponível em : <http://www2.dbd.pucrio.br/pergamum/biblioteca/php/mostrateses.php?open=1\&arqtese $=0610687$ 10_I ndice.html>. Acesso em : 17 maio 2014.

GEBAUER, G. O pensamento antropológico de Wittgenstein. Trad. Milton Camargo Mota. São Paulo: Edições Loyola, 2013.

GLOCK, Hans-Johann. Dicionário Wittgenstein. Trad. Helena Martins. Rio de Janeiro: Jorge Zahar Ed., 1998.

GOTTSCHALK, Cristiane Maria Cornelia. O paradoxo do ensino da perspectiva de uma epistemologia do uso. Disponível em: < http://www.seer.ufu.br/index.php/EducacaoFilosofia/article/view/14866/12707>

Acesso em 25 abr 2015.

JACORZYNSKI, W. La filosofía de Ludwig Wittgenstein como una nueva propuesta para la antropología y las ciencias sociales. Sociológica (Méx.), México, v. 26, n. 74, dic. 2011. Disponível em <http://www.scielo.org.mx/scielo.php?script=sci_arttext\&pid=S0187-

01732011000300006\&lng=es\&nrm=iso>. Acesso em 15 nov. 2014.

KANT, I. Crítica da razão pura. Trad. Alex Marins. São Paulo: Martin Claret, 2003.

MAIA, Leonardo. Deleuze e o perspectivismo. Analógos VIII, pp148-156. Disponível em <http://www.analogos.fil.puc-rio.br/index.php/anais-da-viii-safpuc> Acesso em 10 jun 2014.

MARINS, Imaculada Conceição. Um olhar sobre o perspectivismo de Nietzsche e o pensamento trágico. Revista Trágica: estudos sobre Nietzsche $-2^{\circ}$ semestre de 2008 - Vol.1 - n² - pp.124-141.

MARTINS, Helena. Tradução e perspectivismo. Revista Letras, Curitiba, n. 85, p. 135-149, jan./jun. 2012. Editora UFPR. ISSN 0100-0888. 
A escrita poética de Wittgenstein, sua tradução. Revista Brasileira de Literatura Comparada, n.19, 2011. pp. 109-125. [online] Disponível em <http://www.abralic.org.br/revista/2011/19/124/download> Acesso em 15 jun 2014.

MARUYAMA, Yasushi. Wittgenstein's Children: Some Implications for Teaching and Otherness. Paideia , 1998. Disponível em: < https://www.bu.edu/wcp/Papers/Educ/EducMaru.htm> Acesso em 11 jul. 2014.

Wittgenstein and Teaching. Disponível em: $\langle$ http://wittgensteinrepository.org/agora-alws/article/view/2413/2550 > Acesso em 11 jul 2014.

MONK, R. Wittgenstein: o dever do gênio. Trad. Carlos Afonso Malferrari. São Paulo: Companhia das Letras, 1995.

MOORE, G. E. Princípios éticos; Escritos filosóficos; Problemas fundamentais da filosofia. Trad. Luiz João Baraúna e Pablo Rubén Mariconda. São Paulo: Abril Cultural, 1980. Coleção Os pensadores.

MORENO, Arley R. Wittgenstein e os valores: do solipsismo à intersubjetividade. Revista Natureza humana, v.3, n.2. São Paulo, 2001. Disponível em < http://pepsic.bvsalud.org/scielo.php?pid=S1517-

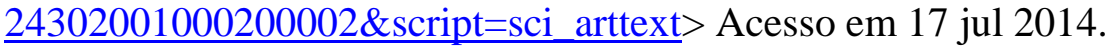

MOTA, Thiago. Nietzsche e as perspectivas do perspectivismo. Cadernos Nietzsche $\mathrm{n}^{\mathrm{o}} \quad 27,2010 . \quad$ [online] Disponível em: $<$ http://www.cadernosnietzsche.unifesp.br/pt/home/item/152-nietzsche-e-asperspectivas-do-perspectivismo> Acesso em 10 jun. 2014.

NIETZSCHE, F. A gaia ciência. Trad. Paulo César de Souza. São Paulo: Companhia das Letras, 2012.

NIETZSCHE, F. Sobre a verdade e a mentira no sentido extramoral. Tradução e apresentação de Noéli Correia de Melo Sobrinho. Disponível em: $<\mathrm{http}$ ://imediata.org/asav/nietzsche_verdade_mentira.pdf $>$. Acesso em 05 maio 2014.

. Genealogia da moral. Disponível em: < https://pensamentosnomadas.files.wordpress.com/2012/11/genealogia-da-morallido.pdf>. Acesso em: 05 maio 2014

PERLOFF, Marjorie. A escada de Wittgenstein: a linguagem poética e o estranhamento do cotidiano. Trad. de Elizabeth Rocha Leite e Aurora Fornoni Bernardini. São Paulo: EDUSP, 2008.

PRADO Jr., Bento. Erro, ilusão, loucura: ensaios. São Paulo: Ed. 34, 2004.

SOUZA, Richer Fernando Borges de. Multinaturalismo, perspectivismo e analítica existencial. Disponível em: <https://www.academia.edu/6395509/Multinaturalismo_Perspectivismo_Amerind io_e_Analitica_Existencial> Acesso em: 17 jul 2014. 